\title{
DELVING INTO COUNTRY RISK
}

Silviatranzo

Documentos ocasionales N. 0802

BANCODE ESPANA

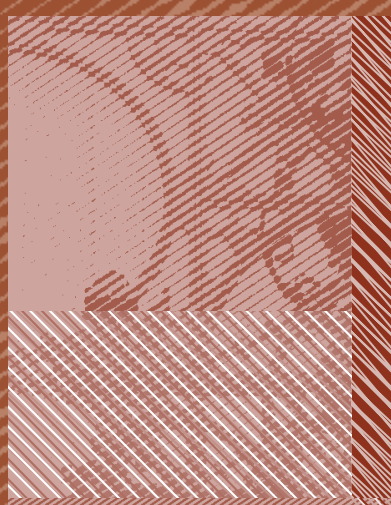

Eurosistema 
DELVING INTO COUNTRY RISK 
DELVING INTO COUNTRY RISK

\section{Silvia Iranzo}

BANCO DE ESPAÑA

$\left.{ }^{*}\right)$ This work was first published as a paper included in the Working Paper series of CUNEF (Colegio Universitario de Estudios Financieros).

The author wishes to thank M. ${ }^{a}$ del Carmen Carrasco, Carlos Pérez de Eulate and Isabel Herrero, from the Country-Risk Service of Bank of Spain, and Juan Badosa and Beatriz Reguero, from CESCE, for providing inputs and useful comments on the paper. 
The Occasional Paper Series seeks to disseminate work conducted at the Banco de España, in the performance of its functions, that may be of general interest.

The opinions and analyses in the Occasional Paper Series are the responsibility of the authors and, therefore, do not necessarily coincide with those of the Banco de España or the Eurosystem.

The Banco de España disseminates its main reports and most of its publications via the INTERNET at the following website: http://www.bde.es.

Reproduction for educational and non-commercial purposes is permitted provided that the source is acknowledged.

@ BANCO DE ESPAÑA, Madrid, 2008

ISSN: 1696-2222 (print)

ISSN: 1696-2230 (on line)

Depósito legal:

Unidad de Publicaciones, Banco de España 


\section{Abstract}

Since the Latin American debt crisis of the early 80s, country risk analysis has accounted for a significant part of the work of research and risk management departments of banks, insurance companies, rating agencies, financial market regulators, and multinational companies.

Country risk is a very broad concept, that includes sovereign risk, transfer risk, and other risks related with international financial activities. Country risk analysis requires delving into multiple fields, such as economics, finance, politics and history. This paper addresses the concept of country risk, the agents involved, the methods for assessing country risk, the payments crises, risk prevention, the assessment of country risk in the present world and the Spanish country risk regulation.

JEL codes: E44, E66, G12, G32, F32, F33.

Keywords: country risk, financial crises, default, solvency, reserves. 


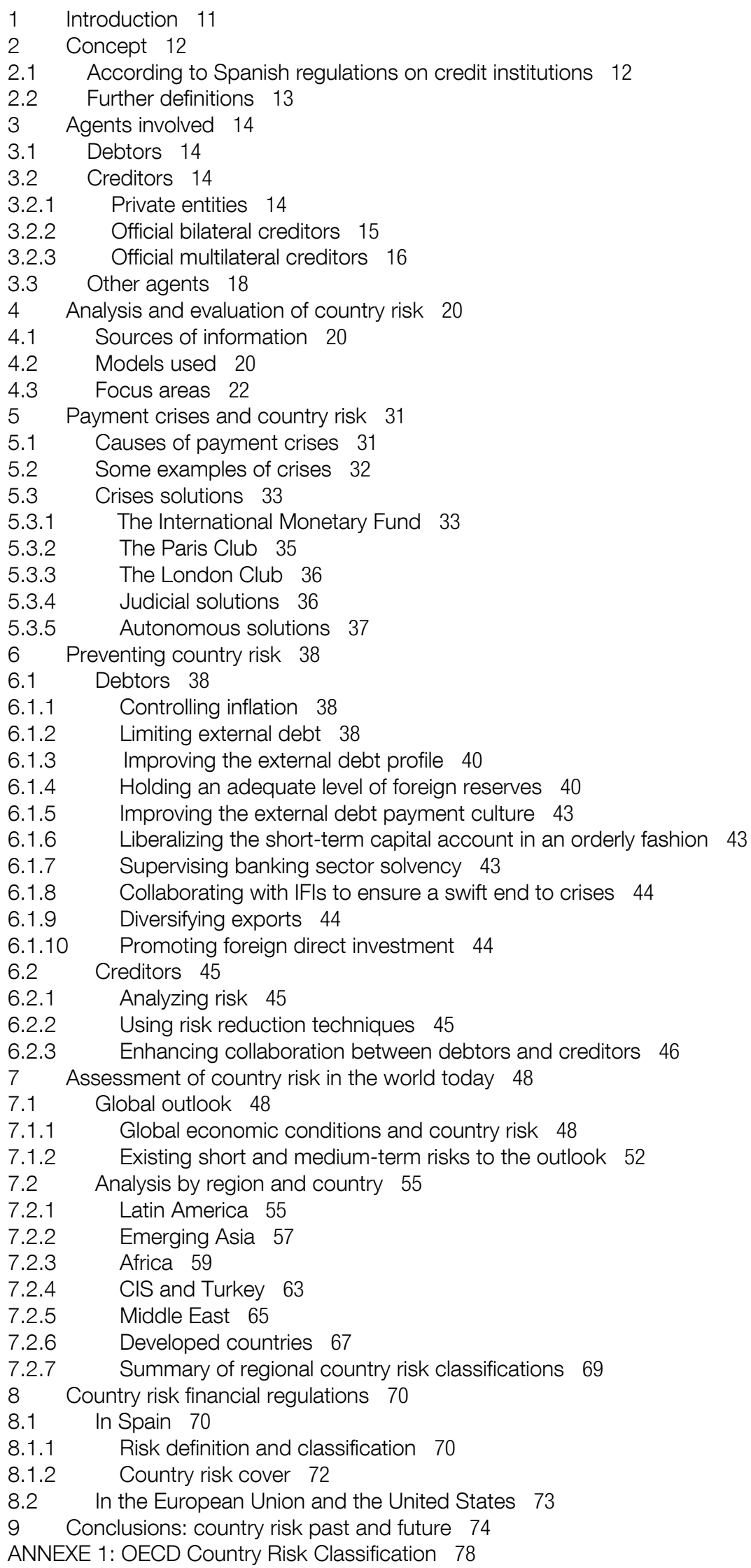


ANNEXE 2: Long-term foreign currency sovereign ratings 83

ANNEXE 3: Circular 4/2004, of 22 December (Annexe IX) 87

REFERENCES 98

\section{TABLES:}

Table 1. IMF funding to member countries, 1997-2007 17

Table 2. Main IMF debtor countries, July 31, 200718

Table 3. EMBI+ by country and region, 2003-2007 25

Table 4. Five year CDS spreads by country, 2004-2007 26

Table 5. Long-term sovereign ratings equivalences 28

Table 6. Variables relevant to the study of country risk 30

Table 7. Foreign reserves ratios for some emerging countries, 200542

Table 8. Main SWFs at 31 December 200642

Table 9. Trade, commodity prices, inflation and interest rates 48

Table 10. World economic growth forecasts (annual percent change) 49

Table 11. Some country risk indicators for developing and emerging markets.1999 and 200650

Table 12. Latin America: GDP, inflation and current account balance 55

Table 13. Latin America: OECD Country Risk Classification, November 200757

Table 14. Emerging Asia: GDP, inflation and current account balance 58

Table 15. Emerging Asia: OECD Country Risk Classification, November 200759

Table 16. Africa: GDP, inflation and current account balance 60

Table 17. Africa: OECD country risk classification, November 200761

Table 18. CIS and Turkey: GDP, inflation and current account balance 64

Table 19. CIS and Turkey: OECD country risk classification, November 200765

Table 20. Middle East: GDP, inflation and current account balance 66

Table 21. Middle East: OECD country risk classification, November 200766

Table 22. Developed countries: GDP, inflation and unemployment 67

Table 23. Selected developed countries: OECD county risk classification, November 200768

Table 24. OECD regional country risk median scores 69

Table 25. Evolution of OECD country risk classifications, 1999-2007 75

Table 26 Moody's, Standard \& Poor's and Fitch sovereign ratings, 1995-2007 76 


\section{Introduction}

Country risk analysis accounts for a significant part of the work of research and risk management departments in banks, insurance companies, rating agencies and financial system regulators. It is also of great interest to many multinational companies.

The concept of country risk began to emerge with the resurgence of large scale international banking activity in the 1950s and became highly relevant in the financial world following the Latin American debt crisis in the early 1980s.

Until the early 1970s, most developing countries could only draw external finance from official bilateral or multilateral sources. This finance was typically of a concessional kind and associated to specific projects. Thereafter, commercial banks started to provide these countries with increasing flows of funds as a response to both the demand for funds fuelled by increasing oil prices after 1973 and the supply of funds (petrodollars) from oil-exporting countries with surplus capital to invest. Following the second oil crisis in 1979, many countries that had amassed significant debts during the 1970s faced payment difficulties, culminating with Mexico's sovereign default in August 1982. The payments crises that arose during the 1980s increased the supervising authorities' concern about international bank risks, particularly in the United States, where losses stemming from loan defaults in Latin American countries brought about some notorious bank failures. As a result, the concept of country risk gained increasing significance, giving rise to new analytical tools and methodologies, as well as country risk regulations.

This report will successively address the concept of country risk, the agents involved, the methods for assessing country risk, the payments crises, risk prevention, assessment of country risk in the present world and country risk regulation. 


\subsection{According to Spanish regulations on credit institutions}

Country risk is a very broad concept. Its analysis requires delving into economic, financial, political, historical and sociological fields. In general terms, country risk is the probability of default in any given country due to macroeconomic, political or social circumstances, or to natural disasters. According to Spanish regulations on credit institutions ${ }^{1}$, country risk is the credit risk (default risk) associated to residents of a given country due to circumstances other than standard commercial risk. Country risk comprises the default risk of sovereign external debt (sovereign risk), and of private external debt when the credit risk is due to circumstances unrelated to the solvency or liquidity status of the private debtor. Default risk arising from the insolvency of the private debtor is known as commercial risk or customer insolvency risk.

External debt can be defined as any debt instrument (loans or bonds) or contingent risk (endorsements, guarantees, deposits or accommodation lines for the undrawn part) contracted by the residents of one country (debtor or issuer) with the residents of the rest of the world (creditors or investors). Foreign participation in the stock capital of companies located in the issuer country (equity) is not considered to be external debt.

"Sovereign risk" is the debt default risk by states or institutions guaranteed by them. Sovereign debt default can occur owing to a lack of public revenues, lack or shortage of foreign currency, or unwillingness of the government to honour the external debt for various political factors.

Where non-sovereign or private debt is concerned, default due to circumstances unrelated to the solvency or liquidity status of the debtor derives typically from "transfer risk", which arises when there is a lack or shortage of foreign currency or foreign currencies in which the external debt is contracted. Transfer risk may appear as a consequence of a serious balance of payments deficit, stemming from an excessive amount of external debt, or due to a confidence crisis leading to massive capital outflows. Foreign debt default may also occur due to other risks, such as balance of payments crises, significant devaluations of the local currency which may lead to insolvency, wars, revolutions, natural disasters, expropriations and nationalizations dictated by foreign authorities, and non-fulfilment of commitments and contracts. These circumstances can lead to external debt default owing to the closure of institutions, the need to set aside existing foreign reserves in order to satisfy more pressing needs, or the bankruptcy of companies due to an excessive increase in the local currency value of external debt owing to a significant devaluation of the exchange rate, or to breach of contract.

The different risks within the concept of country risk are not rigid categories. Instead they are closely linked and they even overlap. For example, transfer risk due to a lack of foreign currency involves both private and sovereign debt, and wars and political conflicts may give rise to significant devaluations which lead to an increase in transfer risk, that affects both private and sovereign debt.

Furthermore, country risk and commercial risks are not always perfectly distinguishable. For example, a private company from a developing country, with an acceptable level of external debt and no liquidity or solvency problems, involved in a business that deals with imported commodities, may become insolvent in the event of a significant

1. Circular $4 / 2004$, of 22 December, to credit institutions, concerning rules on public and confidential financial information, and models of financial statements (BOE, 30 December 2004). 
devaluation of the domestic currency, and must therefore default on its external debt. In this case, both country risk and commercial risks are involved and it becomes necessary to clarify which of the two takes precedence over the other. On the other hand, default on external debt by a private company owing to the enactment of new foreign exchange regulations banning external payments would clearly belong in the country risk field.

Considering the types of risk included in the definition of country risk, the study of this risk category is usually confined to developing and emerging countries, which are more likely to present risks of the sort described.

\subsection{Further definitions}

Risks linked to foreign direct investments are occasionally included as an additional subcategory of country risk. Foreign direct investment risks comprise transfer risk in payments of dividends and divestment proceeds, confiscation risks, expropriation and nationalization risks, breach of contract risks, war, political violence and natural disaster risks. Broadly speaking, these risks are already included in the previous section's definition of country risk. When a country suffers from a high level of country risk for debt instruments, it follows that equity instruments also carry a significant level of country risk, and vice versa.

Another concept that is frequently used in the field of country risk is that of "political risk". Strictly speaking, political risk derives from specific political actions or decisions, and it is therefore one of the types of risk included in the more general concept of country risk described in the previous section. However, various institutions, such as credit insurance companies, use the concept of political risk as a synonym for country risk, as opposed to commercial risk.

The diagram below may help to clarify the concept of country risk:

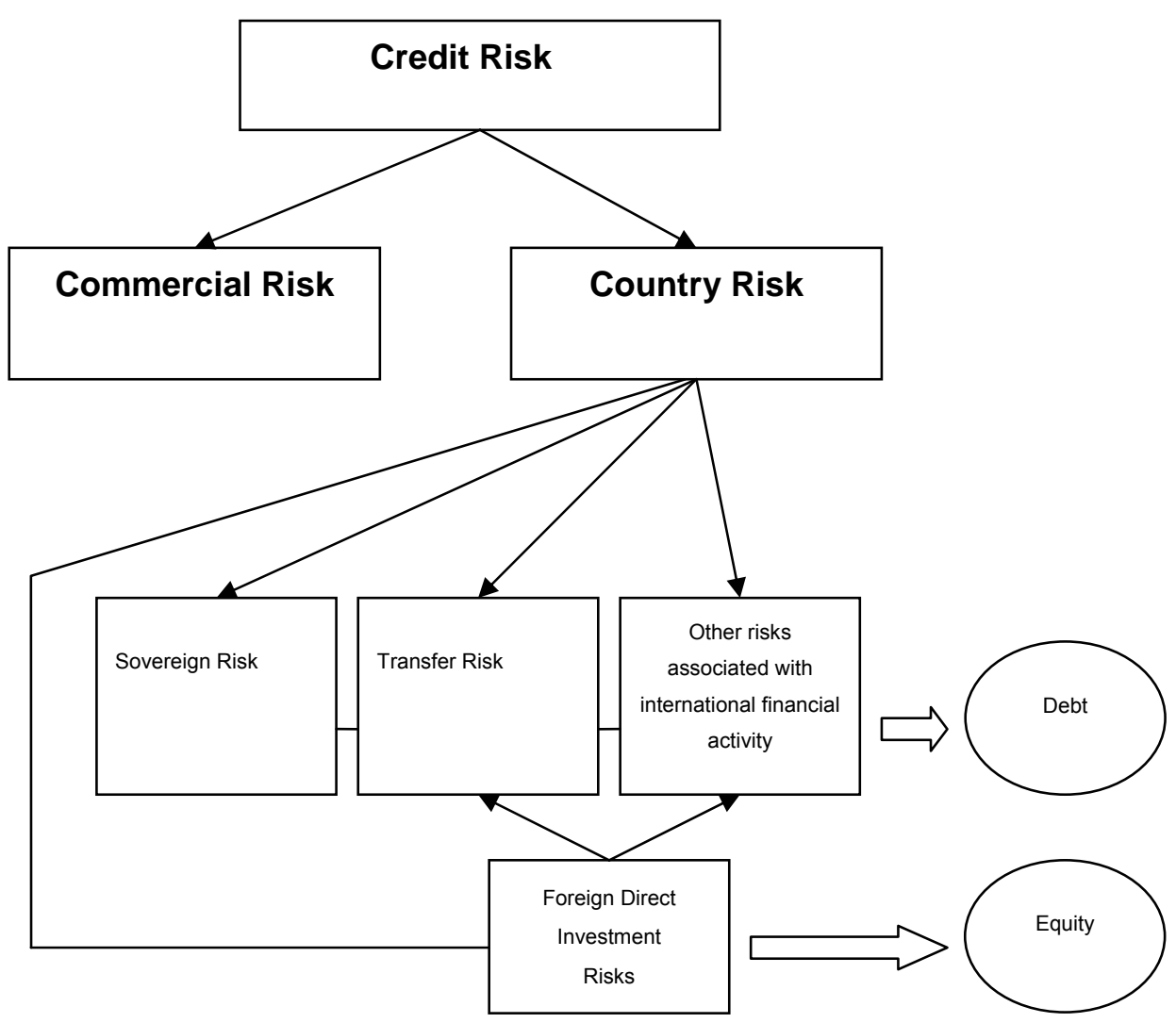




\section{Agents involved}

\subsection{Debtors}

Debtors can be sovereign (or private with a sovereign guarantee) -whether from a state or a local government- or private -typically banks or medium to large companies, that draw funding for their commercial or general operations by means of loans or bond issuance in the international markets.

Despite the fact that any country in the world can be a debtor and therefore undergo assessment for the purposes of country risk, sector analysts usually focus on the economies that are taking off, given that they generate commercial and financial business with other countries and have reached a minimum solvency threshold that allows for political risk coverage from credit insurance companies. Examples of such countries are Brazil, Colombia, Kazakhstan, Ukraine, India, Thailand, Vietnam, Algeria, Morocco, Angola and Nigeria. These countries are usually known as emerging ${ }^{2}$ countries.

Overall capital flows to emerging countries have experienced sustained growth in recent years, reaching $\$ 716.4$ billion in $2005^{3}$. Many emerging countries have become net capital exporters, which have typically chosen to finance developed countries. Some emerging countries that were capital exporters in 2006 include China (the world's leading net capital exporter, at $13.5 \%$ of total), Russia (8.8\%), Algeria (2.3\%) and Venezuela $(2.1 \%)$. Countries at the extreme opposite (net capital importers), include the United States (the world's leading net capital importer at $63.7 \%$ of total), Spain (the world's second highest net capital importer at 7.4\%) and, amongst emerging countries, Turkey (1.9\%).

Despite the considerable increase in funding to emerging countries, the figure is dwarfed by the volume of external capital allocated to developed countries, which reached $\$ 3.6$ trillion in 2004, more than six times the figure allocated to emerging countries ${ }^{4}$.

\subsection{Creditors}

3.2.1 PRIVATE ENTITIES

The first agent to be considered in operations involving country risk is the creditor or investor, notably commercial banks, investment banks, institutional investors (investment funds, pension funds, insurance companies) and hedge funds. Other private companies and individuals also participate directly in the market.

Financing flows provided by banks are the focus of attention of supervisory authorities, who are responsible for ensuring that the international risks of credit institutions do not endanger the solvency and stability of the financial system. Banks with a significant international trading volume usually have departments specializing in the study of country risk.

2. Emerging countries are those that cannot be considered developed countries yet but which do not belong to the category of developing countries either, since their economy has already started to take off. Examples of emerging countries are the BRICs (Brazil, Russia, India and China). Most of South-East Asia is included in the emerging country category, as are countries from Eastern Europe and some African and Latin American countries. The political scientist lan Bremmer has defined emerging countries as those where politics matter to markets at least as much as economics.

3. See Global Financial Stability Report, IMF. April 2007.

4. Ibidem. 
A second relevant category of creditor includes states and governments that bilaterally grant balance of payments finance and export finance to emerging and developing countries. Pure bilateral balance of payments finance usually takes place in the context of agreements between countries that are in a friendly political relationship. This funding is not always public knowledge. Examples of these financial flows are the US Federal Reserve $\$ 700$ million rescue loan to Mexico during the 1982 crisis, the $\$ 343$ million loan by the United States to Russia in $1998^{5}$ and the $€ 835$ million balance of payments loan by Spain to Argentina in 2001.

Where export credits are concerned, the OECD Agreement (or Consensus) on Officially Supported Export Credits rules over export credits granted by countries which are party to the Agreement (United States, Australia, Canada, the European Union, Japan, South Korea, New Zealand, Norway and Switzerland). These credits may be concessional (with conditions that are more favourable than the market) or non-concessional (market conditions). According to the Agreement, concessional credits may be awarded to countries with a per capita income lower than $\$ 3,595$ (2006). Between 1995 and 2005, participants to the Agreement granted export credits (concessional and non-concessional) in excess of 130 billion Special Drawing Rights (SDRs), equivalent to $\$ 228.7$ billion.

Export credit agencies (ECAs) make up a qualified category of creditor in emerging country finance, since without their involvement in guaranteeing medium and long-term bank funding for export operations, many emerging countries would experience notable difficulties in acquiring imported goods, especially capital goods, that are necessary for feeding economic development. ECAs are entities that act as government financial agents, providing finance and credit insurance for operations in which the private sector does not wish to enter, due to the high risks involved, which explains why these agencies are generally controlled by governments. Nonetheless many of them have been privatized in recent years, in some cases retaining management of the riskiest operations and transferring the risks, in terms of their financial result, to the associated state. According to IMF estimates, ECAs are responsible for over $20 \%$ of total debt in emerging and developing countries, and for over $35 \%$ of the debt owed to official bilateral creditors. Furthermore, these countries' debt to ECAs exceeds their debt with multilateral creditors, including the IMF and the World Bank.

Listed below are a few of the most active ECAs:

$\Rightarrow \quad$ Office National du Ducreoire (ONDD), Belgium.

$\Rightarrow \quad$ Export Development Canada (EDC), Canada.

$\Rightarrow \quad$ Compagnie Française d'Assurance pour le Commerce Extérieur (Coface), France.

$\Rightarrow \quad$ Euler Hermes, Germany.

$\Rightarrow \quad$ Sezione Speciale per l'Assicurazione del Credito all'Esportazione (SACE), Italy.

$\Rightarrow \quad$ Atradius, Netherlands.

$\Rightarrow \quad$ Compañía Española de Seguros de Crédito a la Exportación (CESCE), Spain.

$\Rightarrow \quad$ Export Credits Guarantee Department (ECGD), United Kingdom.

$\Rightarrow \quad$ Export-Import Bank of the United States (Ex-Im Bank).

$\Rightarrow \quad$ Sinosure and Eximbank, China.

5. On 24 October 2007, Russia announced the prepayment of the outstanding amounts of this loan, that was taken in 1998 to finance the agricultural sector in the midst of the financial crisis. The final payment of the loan was due in 2020, and its prepayment was driven by political reasons. In Deputy Finance Minister Sergei Storchak's words, "It was unpleasant to keep in our debt portfolio a credit received at the bottom of the national decline". 
ECAs may become creditors of financial flows to emerging countries, whether directly by funding loans, or indirectly as a result of insurance compensation ${ }^{6}$. ECAs are less active in countries that have recorded significant economic progress, given that their low level of country risk does not warrant credit insurance. On the contrary, countries that have not yet embarked on the path towards progress, or whose economic and political situation has deteriorated substantially, do not attract ECAs' interest either, as they do not meet minimum solvency requirements.

The Spanish ECA, CESCE7 , grants cover, not only against the risk of debt instruments and contingent risks but also against the risks of Spanish direct investments abroad. At 31 December 2006, CESCE held medium and long-term risks amounting to $€ 10.3$ billion. The unpaid sums, including from refinancing arrangements, amounted to $€ 1,497$ billion, mostly owed by Cuba and Argentina. The portfolio basically comprised 40 countries that represented just over $94 \%$ of the risks. Three countries accounted each for more than $8 \%$ of the portfolio: Mexico (14\%), Cuba (9.8\%) and Brazil (8.4\%). Other countries where CESCE held considerable levels of risk were Turkey (6.7\%), China (4.9\%), Egypt (4.8\%), Russia (4.5\%), Venezuela (2.5\%) and Argentina (2.3\%). The transport sector accounted for the bulk of the contracts, at $56 \%$ of the total, followed by the petrochemical sector $(20 \%)^{8}$.

According to a recent report published by the Berne Union, main association of credit and investment insurers, the capital invested by its members reached $\$ 113$ billion in 2006. Private sources have singled out Afghanistan as the country with the highest risk cover at the end of 2006, followed by Equatorial Guinea, Tajikistan, Syria, Iraq, Colombia, Angola and Venezuela. Vietnam, Panama and the Ukraine also presented significant levels of cover. Political violence (war, insurgency), asset nationalization and expropriation, and transfer risk were the mains risks covered.

Of late, some private insurance companies have entered the business of credit insurance, spurring sector competition. In 2006, private insurers made up half of the market, despite not operating in the longer term segments. Private companies are nevertheless at a disadvantage compared to public ones in negotiating repayment conditions with foreign governments, as the former cannot take government support for granted in these negotiations.

\subsubsection{OFFICIAL MULTILATERAL CREDITORS}

The International Financial Institutions (IFIs) are major creditors of countries with considerable levels of country risk. Among these institutions, particular reference must be made to the International Monetary Fund (IMF).

6. The insurance does not normally cover $100 \%$ of the credit so as to avoid moral hazard, which occurs when a person or entity's behaviour changes when insured.

7. CESCE (Spanish Export Credit Insurance Corporation) was set up in 1971 to manage export credit insurance on behalf of the state (political risk cover), as part of export promotion policies. The Spanish state holds $50.25 \%$ of the capital, the rest being shared between the main Spanish financial institutions and insurance companies.

The following regulations govern its activity: Law 10/1970, of 4 July, which amends the export credit insurance system (BOE, 7 July 1970); Decree 3138/1971, of 22 December, regulating export credit insurance (BOE, 23 December 1971); Order of 12 February 1998 on state cover of risks derived from foreign and international trade (BOE, 21 February 1998); Royal Decree 1327/1999, of 31 July, regulating certain aspects of state export credit insurance in medium and longterm operations (BOE, 3 September 1999); and Order ECO/180/2003, of 22 January, on state cover of risks derived from foreign trade, foreign investments and foreign economic transactions (BOE, 7 February 2003).

Since 1990, the year in which the insurance market was liberalized, CESCE has become an active participant in the free market of independent export credit insurance (commercial risks) and in domestic credit insurance.

8. See CESCE 2006 Annual Report. 
The IMF is an international organization made up of 185 countries. It was founded in 1944, and for many years it was, along with the World Bank, a fundamental pillar of the Bretton Woods system, that acted as a guardian of the international economic and monetary order until the early 1970s. The IMF no longer contributes towards guaranteeing stability of the exchange rates, as it did during its initial 27 years of existence, but it has played an important role in supplying funds to developing countries with payment difficulties. Furthermore, it holds an essential position in maintaining economic discipline and orthodox economic policies in its member countries, through the recommendations included in its periodical country reports under Article IV of its Articles of Agreement, and in its reports and studies on the state of the international economy.

The IMF has played an essential role as moneylender in settling external imbalances, by supplying funds in the event of balance of payments crises, and cancelling debts in the context of the MDRI Initiative (Multilateral Debt Reduction Initiative). Furthermore, its role as a technical adviser and guarantor of debtors' financial discipline in the context of debt refinancing and cancellations granted by Paris Club creditors -restructuring forum for loans granted by governments or guaranteed by them- has made this institution a key player in reducing country risk. The assessments carried out by the IMF on external debt sustainability (Debt Sustainability Assessments -DSA) are crucial in determining the result of Paris Club negotiations.

To sum up, the IMF fulfils three main roles in the area of country risk: moneylender in the event of external payment crises, technical adviser, and guarantor for Paris Club debt renegotiation agreements. The first role listed is currently in decline, due to the favourable situation of balances of payments worldwide. As a result, the outstanding balance of overall debt to the IMF has dropped sharply, not only because its funding is much less sought-after but also because many countries, including Argentina, Brazil, Mexico, Peru, Uruguay, Russia and Indonesia, have opted to prepay their debts with the IMF.

Table 1. IMF funding to member countries, 1997-2007

\begin{tabular}{|c|c|c|c|c|}
\hline & $\begin{array}{l}\text { Disbursements } \\
\text { Withdrawals }^{*} \\
\left.\text { and Loans }{ }^{\star \star}\right)\end{array}$ & Repayments & $\begin{array}{l}\text { Interest charged } \\
\text { by the IMF }\end{array}$ & $\begin{array}{l}\text { Total Credit } \\
\text { Outstanding }\end{array}$ \\
\hline & \multicolumn{4}{|c|}{ (in millions of Special Drawing Rights) } \\
\hline 2007 (Jan-Jul) & $1,069.2$ & $3,514.8$ & 269.2 & $11,221.1$ \\
\hline 2006 & $2,874.9$ & $23,922.5$ & $1,140.1$ & $13,666.7$ \\
\hline 2005 & $2,692.5$ & $30,118.1$ & $2,234.4$ & $34,714.3$ \\
\hline 2004 & $4,983.1$ & $14,756.2$ & $2,338.2$ & $62,139.8$ \\
\hline 2003 & $21,171.5$ & $19,728.2$ & $2,395.1$ & $71,913.0$ \\
\hline 2002 & $26,581.4$ & $16,013.5$ & $2,293.5$ & $70,469.7$ \\
\hline 2001 & $24,634.3$ & $14,054.6$ & $2,203.8$ & $59,901.8$ \\
\hline 2000 & $7,670.5$ & $15,844.5$ & $2,413.0$ & $49,322.1$ \\
\hline 1999 & $10,746.9$ & $19,990.6$ & $2,609.3$ & $57,496.1$ \\
\hline 1998 & $21,482.1$ & $7,311.2$ & $2,521.6$ & $66,739.8$ \\
\hline 1997 & $16,843.5$ & $6,283.6$ & $1,609.8$ & $52,568.9$ \\
\hline
\end{tabular}

Source: IMF.

* Withdrawals from the General Resources Account.

** Loans drawn from the PRGF (Poverty Reduction and Growth Facility), SAF (Structural Adjustment Facility), ESAF (Enhanced Structural Adjustment Facility) and Trust Fund programmes. 
Table 1 shows a sharp fall in disbursements made by the IMF during the last five years, amounting in 2005 and 2006 to only $16 \%$ and 17\% respectively of the previous eight year average, which was 16.8 billion SDRs. A marked increase in repayments and prepayments is also reflected, reaching record figures in 2005 and 2006 that exceeded disbursements by a factor of eight. These dynamics lie at the heart of the IMF's current lack of resources to cover its operating costs, given that this institution secures its income with revenues that represent the difference between the interest charged on loans and that paid for the funds received.

Table 2. Main IMF debtor countries, July 31, 2007

\begin{tabular}{|c|r|r|l|l|l|r|}
\hline \multirow{2}{*}{ Country } & Turkey & Iraq $^{\star}$ & $\begin{array}{l}\text { Dominican } \\
\text { Republic }\end{array}$ & Georgia $^{\star *}$ & Kenya $^{\star \star}$ & Armenia $^{\star *}$ \\
\cline { 2 - 7 } & \multicolumn{6}{|c|}{ (in millions of Special Drawing Rights) } \\
\hline Amount owed to IMF & 5,074 & 297 & 292 & 150 & 135 \\
\hline
\end{tabular}

Source: IMF.

* Stand-by Agreements

** PRGF Programmes

Table 2 shows IMF debtor countries with an outstanding debt balance higher than 100 million SDRs. Clearly Turkey is the main debtor, owing the IMF a significantly higher amount than the rest of countries.

The World Bank and other Multilateral Development Banks act as moneylenders for long-term projects in countries that do not exceed a minimum per capita income threshold ${ }^{9}$, presumably having a difficult access to affordable long-term funds in credit markets. In 2006, World Bank loans, including those from its concessional arm, IDA (International Development Association), reached a total of $\$ 20.7$ billion. The quoted figure is very small relative to total external flows currently received by emerging and developing countries.

\subsection{Other agents}

The Organization for Economic Cooperation and Development (OECD) plays two important roles in the area of country risk. Firstly, it enacts the regulations that rule export credits, grouping them under what has become known as the Agreement -or Consensus- on Officially Supported Export Credits ${ }^{10}$. This Agreement dates back to 1976 and its goal is to establish a level playing field when granting medium and long-term export credits, so as to prevent creditor countries from setting more favourable financial conditions in export contracts than those warranted by the market. The Consensus is accepted as an exception to the World Trade Organization's Agreement on Subsidies and Countervailing Measures. Current Participants in the Consensus are Australia, Canada, the European Union, Japan, South Korea, New Zealand, Norway, Switzerland and the United States.

9. The eligibility threshold for 17-year World Bank loans is \$3,595 of per capita income (2006).

10. The Agreement does not apply to export credits for agricultural or military goods. 
The second important role that the OECD plays in the area of country risk is to publish a rating for nearly every country in the world based on the degree of country risk. This rating is produced by the Subgroup of Country Risk Experts, and is available to the general public, being an important reference for all country risk experts. However, its main goal is to help determine the minimum level of credit insurance premia that the ECAs may charge in their insurance contracts for each risk category. Annexe 1 presents the updated version at 30 November 2007 of the OECD country risk classification. The methodology used to produce this risk classification will be discussed later.

Lastly, country risk analysis departments of international banks, institutional investors, insurance companies, rating agencies, other risk rating agencies and national supervision offices, most often central banks, are outstanding agents in the field of country risk, as they provide analyses and assessments on the country risk level of the different regions and countries of the world. These assessments are generally of an independent nature, albeit not always available to the general public. 


\section{Analysis and evaluation of country risk}

\subsection{Sources of information}

Information on country risk covers many fields of knowledge given the multiple nature of the factors which lie at the heart of the risks. Information sources can be classified as public and private. Public sources include governments and their statistics agencies, publicly-owned ECAs, central banks, IFls and multilateral organizations. Private sources include rating agencies and other rating bodies, commercial and investment banks, insurance companies and the media in general, particularly the press. Moreover, various associations, policy institutes and research centres, which can be both public and private, also provide useful information for the study of country risk. The diagram below provides a summary of the information sources, featuring some examples of each type of source on the right hand side of the diagram.

\begin{tabular}{|c|c|c|c|}
\hline \multirow{6}{*}{ 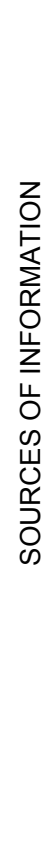 } & & $\begin{array}{l}\text { Governments, } \\
\text { ECAs, } \\
\text { Central banks }\end{array}$ & $\begin{array}{l}\text { Bank of Spain, Spanish Commerce } \\
\text { Department, Spanish Treasury, } \\
\text { Embassies, CESCE }\end{array}$ \\
\hline & Public & Multilateral Organizations & $\begin{array}{l}\text { IMF, World Bank, OECD, Paris Club, } \\
\text { Bank for International Settlements }\end{array}$ \\
\hline & & $\begin{array}{l}\text { Rating agencies, } \\
\text { Other rating bodies }\end{array}$ & $\begin{array}{l}\text { Moody's, Standard \& Poor's, Fitch, } \\
\text { EIU Country Risk Service }\end{array}$ \\
\hline & \multirow{3}{*}{ Private } & Banks and insurance companies & $\begin{array}{l}\text { Goldman Sachs, JP Morgan, Aon } \\
\text { Carvajal }\end{array}$ \\
\hline & & $\begin{array}{l}\text { Various private centres and } \\
\text { policy institutes }\end{array}$ & $\begin{array}{l}\text { Institute of International Finance, } \\
\text { Institutional Investor, Fraser Institute }\end{array}$ \\
\hline & & Media & $\begin{array}{l}\text { National and foreign press and } \\
\text { magazines }\end{array}$ \\
\hline
\end{tabular}

\subsection{Models used}

The study of country risk is intrinsically an unsystematic discipline and as such it deals with a highly unpredictable type of risk ${ }^{11}$. Agencies with huge resources and intelligence networks, such as the CIA, were unable to predict the invasion of Afghanistan or the overthrow of the Shah of Iran. Debt risk varies enormously, depending on the starting assumptions that are formulated about world economy and politics, or the performance of the different governments. In addition to the difficulty in defining the starting assumptions, there is a

11. See Joseph Khoury, Sarkis and Zhou, Chunsheng: "Country risk: existing models and new horizons". Handbook of International Banking. Edited by Andrew W. Mullineux and Victor Murinde. Edward Elgar. Cheltenham, UK. Northampton, MA, USA. See also Hiranya K. Nath. "Country Risk Analisis: A Survey". March 2004. Southern Methodist University. 
frequent lack of availability, reliability and timeliness ${ }^{12}$ in the wealth of data required to carry out the analysis. All this explains why financial lending institutions often set out conditions (covenants) in financial contracts. Examples of such covenants are specific limits for the country's overall debt ${ }^{13}$, adequate information provided by the debtor, compulsory membership of the IMF, etc. Failure to comply any of these conditions by the debtor could trigger actions by the creditor, such as increases in spreads or demand of prepayment of the outstanding debt.

The evaluation of country risk inevitably rests on human judgment, particularly when analyzing political risk. Despite these inherent difficulties, many banks and research centres have tried to find ways to assess country risk using risk models. According to the Ex-Im Bank classification, there are four types of country-risk models:

$\Rightarrow$ Purely qualitative

$\Rightarrow$ Structured qualitative, with some statistical data

$\Rightarrow$ Structured qualitative with scoring techniques (or checklists)

$\Rightarrow$ Quantitative (econometric and highly structured).

Purely qualitative methods for assessing country risk lack a fixed structure and generally consist of reports addressing the different aspects which contribute towards the evaluation of country risk, such as the political and social situation, the economic situation and structure, or the status and prospects of the external sector. The advantage of this method is its flexibility, as it does not have to adapt to any predetermined structure. Its main disadvantage is the difficulty to draw comparisons between the level of risk in different countries for the purpose of deriving country groupings and rankings by risk level.

Structured qualitative methods combine qualitative and quantitative methods. They consist of a qualitative system built on a standard structure or format, enabling more comparisons to be made than the purely qualitative method. The political risk index produced by Business Environment Risk Intelligence (BERI) is an example of such method.

The scoring structured method, also known as the checklist method, is a structured qualitative method commonly used in the analysis of country risk by some banks and rating agencies. It requires the definition of a series of political, social, historical, macroeconomic and financial indicators, which can be of a qualitative or quantitative nature, and the allocation of a score within a defined range to each one of them, with a minimum and a maximum value. A weight is assigned to each indicator to alter the influence that each variable has on the overall score. The sum of weighted individual scores is the final country risk rating, which can be compared with other countries' scores. This method is called the weighted checklist approach, which is popular with many rating agencies and risk assessment units.

Amongst the quantitative models, that calculate the "probability of default" (PD), reference can be made to the probit and logit models introduced by Jeffrey Sachs (one of the pioneers) and Balkan. A widely accepted quantitative model is the econometric method used

12. The lack of timeliness of external debt data may lead the borrower to supply the creditor with data that underestimates real debt due to debt incurrence since the date to which the data supplied refer to and the time of negotiating with the creditor.

13. It is interesting to analyze what is included in the concept of debt. For example, should foreign direct investment be included? Obviously, these flows could increase the demand for foreign currency for transfer of dividends, royalties, etc. Should private bank debt be included? Should gross or net debt be considered? Many analysts back the inclusion of direct investment, private debt and net debt, because doing so allows for more realistic calculations of foreign currency demand. 
by the OECD to perform its country risk classification. This model, known as the Country Risk Assessment Model (CRAM), combines a quantitative econometric approach with qualitative valuations. It is based upon the model developed by the Belgian ECA (ONDD). The details of the model are confidential. It is used by the OECD's Subgroup of Country Risk Experts to derive the country risk classification that determines the minimum export credit insurance premia charged by ECAs. The CRAM model sets out three categories of risk indicators, each made up of a series of indicators:

a) Payments record reported by ECAs

b) Financial situation

c) Economic situation

Individual quantitative assessments are performed on the indicators of each category, based on predefined ranges for each indicator. The scores are given a flexible weighting using a common methodology to all countries analyzed. The weighted values are grouped in order to draw a single value for each of the three categories. Subsequently the three values are merged into one, which is the CRAM model provisional result, determining the country's inclusion into one of eight risk categories. These categories are numbered from "0" to "7", "0" being the rating associated to low-risk countries, namely "high income" countries according to the World Bank per capita income criteria ${ }^{14}$, and "7" is the rating associated to the highest-risk countries. The OECD also rates some IFIs and multilateral organizations.

In a subsequent phase, the provisional result of the model is analyzed by the OECD Subgroup of Country Risk Experts through a qualitative assessment of the result, bringing on board political factors or other features that the CRAM model did not take into consideration. This final assessment may result in a readjustment, adopted by consensus, of the model's quantitative result. The minutes of the Subgroup's meetings are confidential but the updated list of country risk ratings is made public at once.

The OECD country risk rating is permanently reviewed by the Subgroup of Country Risk Experts, including at least once a year or each time a "fundamental" change emerges in the country's situation.

Some quantitative models combine analytical tools with an early crisis warning system. These systems involve defining values for selected indicators that could possibly trigger a payments crisis. These models have generally been unsuccessful, due to the high frequency of "false positives", as well as shortcomings in the quality and timeliness of data. It may be concluded that no model or early warning system should disregard qualitative analysis, owing to the proven difficulty to model political risk.

\subsection{Focus areas}

This section will deal with the different aspects that can influence country risk. These aspects cover various areas, their importance depending on the particular circumstances of each country. They relate to politics, history, culture, macroeconomy, microeconomy, economic structure, financial sector and external sector. These fields are interdependent, and they reinforce each other through various means. Furthermore, the general context of the international economy and markets can bear a considerable influence on all of these aspects.

14. Countries eligible for graduation from World Bank funding are "high income" countries, defined as those with a per capita income equal to or greater than $\$ 11,116$ (figure set for 2006). 
The following paragraphs outline the variables that are typically analyzed, grouped into six basic fields: politics, macroeconomy, economic structure, banking sector, external sector and market assessments. These variables must be studied in both static and dynamic contexts. The listed variables are not meant to be exhaustive. Moreover, the areas analyzed in each country may vary, whether in terms of their selection or the emphasis placed on each of them, depending on the country's history, location, structure and specific circumstances.

Analysis of the political field requires looking at countries' political stability, government effectiveness, strength of institutions, risk of internal or external political conflict, proximity or inclusion in a geographical area that is politically or militarily conflictive, degree of corruption and debt payment culture. Political risk can be measured using the World Bank Governance Indicators (WGI). Governance consists of the traditions and institutions by which authority in a country is exercised. This includes the process by which governments are selected, monitored and replaced; the capacity of the government to effectively formulate and implement sound policies; and respect of citizens and the state for the institutions that govern economic and social interactions among them ${ }^{15}$.

In the macroeconomic area, the analysis focuses on the economic growth rate and its volatility over time, the inflation rate, monetary policy credibility and instruments, the level of nominal and real interest rates, public sector balance sheet and, in the case of deficit, funding sources, level of government borrowing and degree of development of the local bond market.

The economic structure analysis requires looking at per capita income and income distribution, social mobility, size of the country, product diversification, export concentration in a few goods or services and energy dependence.

In the banking sector, the variables to assess are non-performing loans ratio, bank profitability, foreign bank penetration, domestic savings rate, access to bank credit, balance of foreign currency assets and liabilities, existence of a deposit insurance institution, and effectiveness of banking supervision.

The foreign sector field requires analysis of the trade and current account balances, the level of foreign direct and portfolio investment, the existence of foreign exchange regulations, the exchange rate system and devaluation record, the level and structure of foreign debt, the Paris Club refinancing history, and the level of foreign exchange reserves.

The markets also provide valuable information about a country's default risk, through indicators such as sovereign spreads - difference between bond yields of sovereign dollardenominated debt and 10-year US treasury bonds- and the Credit Default Swap spread. An important market reference is the Emerging Markets Bond Index Plus (EMBI+), that tracks yields for traded external debt instruments in the emerging markets. In addition to these indicators, an important market reference is the long-term foreign currency sovereign ratings assigned by rating agencies.

15. The World Bank Governance Project reports aggregate and individual indicators for 212 countries and territories over the period 1996-2006, for six dimensions of governance: Voice and Accountability; Political Stability and Absence of Violence; Government Effectiveness; Regulatory Quality; Rule of Law; and Control of Corruption. The indicators are based on data from 25 different organizations, including the World Bank itself, Gallup International, Economist Intelligence Unit, Institute for Management Development (IMD), DRI/Mc Graw-Hill, University of Columbia, Freedom House, Afrobarometer, Latinobarómetro, the World Economic Forum and Reporters without Borders. 
The EMBI+ index published by the US investment bank JP Morgan is the bestknown index for measuring country risk from a market perspective. The EMBI+ was first published in July $1995^{16}$, with the goal of creating a reference for the yield of an emerging market debt portfolio. The index comprises 108 instruments from 16 countries: Argentina, Brazil, Bulgaria, Colombia, Ecuador, Egypt, Mexico, Panama, Peru, Philippines, Indonesia, Russia, South Africa, Turkey, Ukraine and Venezuela. In order to be part of the EMBI, debt instruments must have a minimum outstanding nominal value of $\$ 500$ million.

The EMBI index includes Brady bonds, Eurobonds, loans and debt instruments of sovereign issuers, denominated in foreign currency, mainly US\$. Since 31 May 2002, debt subject to local law cannot be included in the index, inclusion being limited to issues with legal jurisdiction in a G-7 country. Since the index includes emerging country dollar-denominated debt, the countries' sovereign rating upon entry in the index cannot be better than BBB+ or Baa1. The index is usually expressed as a spread or differential, in basis points, with respect to 10-year US Treasury bond yields ${ }^{17}$.

JP Morgan's EMBI Global index is an extended version of the $\mathrm{EMBI}+$, that aims to be more fully representative of emerging countries than the EMBI+. As such, it covers a broader range of debt securities (with lower requirements in terms of degree of liquidity) and a larger number of countries (low or medium income countries -with a per capita income of less than $\$ 11,116$ in 2006- according to the World Bank). Some of these countries enjoy an investment grade better than BBB+ or Baa1. Specifically, the EMBI Global comprises 27 countries, including countries like Poland, Malaysia, Nigeria, China, Morocco, Algeria and Chile, in addition to those included in the EMBI+.

The EMBI has recently become somewhat less relevant as an indicator of emerging market risk, since dollar-denominated bonds only represent around $28 \%$ of outstanding emerging market sovereign debt. The remaining $72 \%$ of the debt is made up of bonds denominated in local currency, which have earned a considerable degree of interest by international investors. This explains why JP Morgan introduced a new index for assessing emerging market risk, the Government Bond Index-Emerging Markets (GBI-EM), that tracks local currency sovereign debt for 19 emerging countries: Argentina, Brasil, Chile, China, Colombia, Czech Republic, Egypt, Hungary, India, Indonesia, Malaysia, Mexico, Peru, Poland, Russia, Slovakia, South Africa, Thailand and Turkey.

16. The immediate predecessor of the EMBI+ is the EMBI. This index, created by JP Morgan in 1992, only includes Brady bonds.

17. The instruments included in the $\mathrm{EMBI}+$ must first meet four eligibility criteria: minimum outstanding capital of $\$ 500$ million, rating of $\mathrm{BBB}+$ or Baa1 or below, residual maturity of more than a year and the possibility of international liquidation (via Euroclear for example). 
Table 3. EMBI+ by country and region, 2003-2007

\begin{tabular}{|c|c|c|c|c|c|c|}
\hline & $\begin{array}{r}30 \\
\text { Nov } 2007\end{array}$ & $\begin{array}{r}31 \\
\text { May } 2007\end{array}$ & $\begin{array}{r}31 \\
\text { Dec } 2006\end{array}$ & $\begin{array}{r}31 \\
\text { Dec } 2005\end{array}$ & $\begin{array}{r}31 \\
\text { Dec } 2004\end{array}$ & $\begin{array}{r}31 \\
\text { Dec } 2003\end{array}$ \\
\hline & 246 & 153 & 169 & 245 & 356 & 418 \\
\hline Africa & 153 & 68 & 74 & 145 & 177 & 232 \\
\hline Asia & 234 & 140 & 156 & 302 & 457 & 333 \\
\hline Europe & 200 & 128 & 139 & 151 & 216 & 255 \\
\hline Latin America & 271 & 168 & 186 & 283 & 420 & 521 \\
\hline Argentina & 401 & 277 & 216 & 504 & 4,703 & 5,632 \\
\hline Brazil & 220 & 142 & 192 & 311 & 382 & 463 \\
\hline Bulgaria & 134 & 56 & 66 & 90 & 77 & 177 \\
\hline Colombia & 200 & 117 & 161 & 238 & 332 & 431 \\
\hline Ecuador & 616 & 620 & 920 & 669 & 690 & 799 \\
\hline Egypt & 173 & 43 & 52 & 58 & 107 & 138 \\
\hline Indonesia & 265 & 150 & 164 & 126 & 166 & 199 \\
\hline Mexico & 148 & 75 & 98 & 126 & 166 & 199 \\
\hline Panama & 195 & 119 & 148 & 246 & 290 & 335 \\
\hline Peru & 188 & 100 & 118 & 206 & 220 & 312 \\
\hline Philippines & 228 & 138 & 154 & 302 & 457 & 415 \\
\hline Russia & 159 & 87 & 96 & 118 & 213 & 257 \\
\hline South Africa & 149 & 72 & 81 & 85 & 95 & 141 \\
\hline Turkey & 247 & 181 & 207 & 223 & 265 & 309 \\
\hline Ukraine & 278 & 100 & 132 & 183 & 231 & 258 \\
\hline Venezuela & 531 & 259 & 182 & 318 & 411 & 593 \\
\hline
\end{tabular}

Source: JP Morgan

EMBI+ by region, 2002-2007

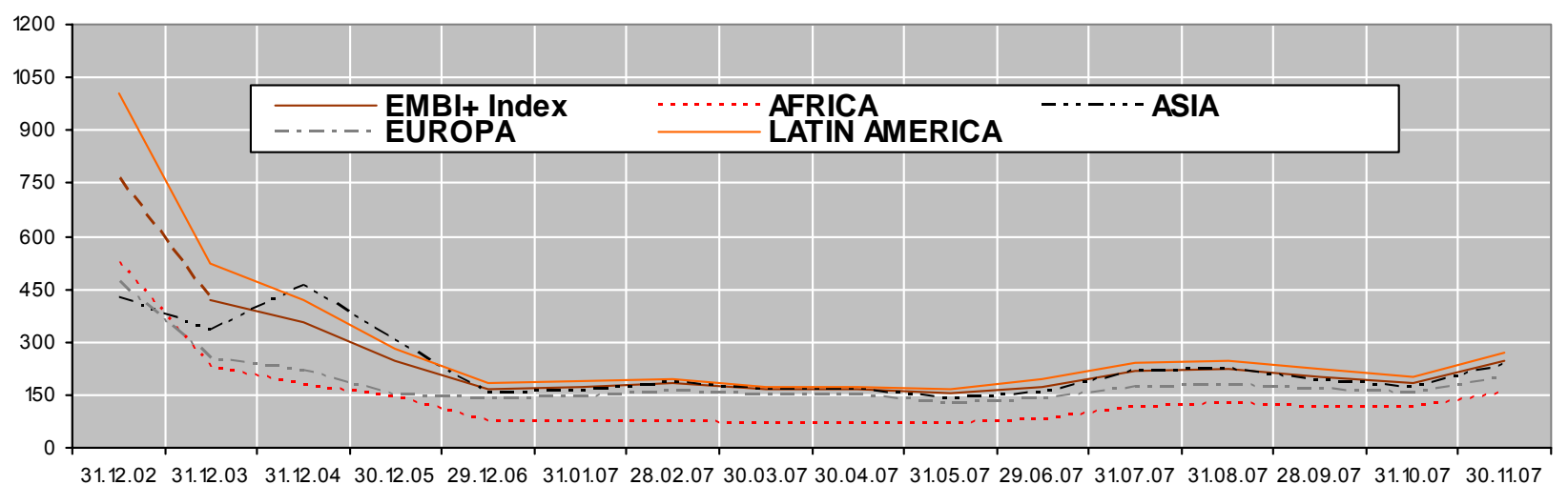


Another market indicator for assessing country risk is the credit default swap (CDS) spread. Credit default swaps are over-the-counter traded financial derivatives which enable transfer of credit risk. The protection buyer transfers the risk of a specified "credit event" to the protection seller, including bankruptcy, non-payment, restructuring, non-fulfilment of obligations, repudiation, etc., by a company or sovereign issuer (reference entity). The protection buyer pays a periodic premium on top of the nominal premium, usually expressed as an annual rate, known as spread, until the contract expires or until occurrence of the aforementioned credit event.

The CDS premium provides information about the credit quality of the reference entities, given that the contract enables credit risk insurance. Spread increases point to risk heightening; falls point to risk reduction. When the reference entity is a sovereign state, the CDS premium can be used as an indicator of sovereign risk. Table 4 shows some CDS spreads for emerging countries at 30 November 2008.

Table 4. Five Year CDS spreads by country, 2004-2007

\begin{tabular}{|c|c|c|c|c|c|}
\hline & $\begin{array}{r}30 \\
\text { Nov } 2007\end{array}$ & $\begin{array}{r}31 \\
\text { May } 2007\end{array}$ & $\begin{array}{r}31 \\
\text { Dec } 2006\end{array}$ & $\begin{array}{r}31 \\
\text { Dec } 2005\end{array}$ & $\begin{array}{r}31 \\
\text { Dec } 2004\end{array}$ \\
\hline Argentina & 476 & 192 & 204 & 377 & - \\
\hline Brazil & 98 & 61 & 99 & 221 & 308 \\
\hline Bulgaria & 68 & 12 & 13 & 35 & 35 \\
\hline Colombia & 137 & 77 & 114 & 166 & 289 \\
\hline Croatia & 64 & 14 & 19 & - & - \\
\hline Indonesia & 158 & 98 & 120 & - & - \\
\hline Malaysia & 45 & 14 & 17 & 26 & 25 \\
\hline Mexico & 67 & 28 & 40 & 57 & 80 \\
\hline Panama & 125 & 62 & 84 & 147 & - \\
\hline Peru & 120 & 61 & 91 & 223 & - \\
\hline Philippines & 160 & 100 & 113 & 260 & 474 \\
\hline Poland & 26 & 9 & 13 & - & - \\
\hline Romania & 70 & 16 & 19 & 37 & - \\
\hline Russia & 93 & 39 & 44 & 67 & 128 \\
\hline South Africa & 63 & 25 & 42 & 38 & 53 \\
\hline South Korea & 49 & 15 & 17 & 23 & 30 \\
\hline Turkey & 179 & 143 & 161 & - & 228 \\
\hline Ukraine & 242 & 130 & 155 & - & - \\
\hline Venezuela & 478 & 194 & 129 & 218 & 299 \\
\hline
\end{tabular}

Source: JP Morgan. 
Market indicators, such as EMBI Plus and CDS spreads give an instant idea of market assessments of country risk, measured through the associated risk premia. In this respect these indicators provide an important reference for issuers and investors. However, they hold two disadvantages for country risk analysts. The first is the overvaluation of shortterm events, which can lead to significant changes in premium levels which do not reflect true country risk. The second is the fact that these indicators reflect changes in country risk attributable not only to factors specific to the country but also to factors which are beyond its control, such as the international economic situation or the level of liquidity in financial markets.

Sovereign long-term foreign currency ratings measure the default risk of sovereign external debt, arising from a lack of ability or willingness to pay. In order to produce sovereign ratings, rating agencies take into consideration a series of indicators that may vary in each case, but they largely match those that have already been mentioned above ${ }^{18}$.

Standard \& Poor's and FitchRatings use the same long-term foreign currency sovereign debt scale. However, Moody's has its own scale. Table 5 shows the rating scales of the three agencies. The ratings are ranked from best to worst as scanning the table from top to bottom. The ratings in any single row are associated to the same level of risk assessment. A rating equal to or worse than BB+ (Standard \& Poor's and Fitch) or Ba1 (Moody's) is deemed "speculative" or "junk", whilst investment grade applies to ratings equal to or better than BBB- (Standard \& Poor's and Fitch) or Baa3 (Moody's). Investment grade is awarded to countries with manageable levels of debt, good foreign income prospects and a fine payment record. Many institutional investors, such as pension funds, are expressly forbidden by their articles from acquiring bonds with a speculative grade, which highlights the importance for an issuer country to be granted investment grade from rating agencies, as the increase in demand for bonds by institutional investors results in a quick drop in debt spreads, with the associated public spending savings for the issuer country.

Three rating agencies, Moody's, Standard \& Poor's and Fitch, control 95\% of the market, the first two accounting for roughly $80 \%$ of the business. Moody's is the main credit rating agency. The ratings market has multiple barriers to entry. Since 1975, the US stock market regulatory agency, the Securities and Exchange Commission (SEC), has only awarded six companies a licence to operate ${ }^{19}$.

\footnotetext{
18. The variables considered by the agencies in order to produce sovereign ratings are the following: a) Political, demographic and educational factors, as well as international relations; b) Economic structure, per capita income and dynamism of the private sector; c) Level and prospects of long-term growth and GDP composition; d) Labour market; e) Macroeconomic policy; f) Monetary stability, monetary indicators and internal and external liquidity indicators; g) Sovereign debt and fiscal flexibility; h) Banking and finance; i) Balance of payments and foreign assets and liabilities; j) Trade policy and foreign investments; and k) Public and private sector external debt.

19. Some critics have recently pointed out that rating agencies are excessively powerful and that the ratings issued are not completely reliable due to the conflicts of interest inherent to their business, since it is the issuers (be they public or private), and not the users, who pay for the rating. When the agencies fail with their ratings, as happened in the wellknown cases of Enron, WorldCom, Parmalat and the asset-backed securities derived from subprime mortgages, the agencies cannot be held legally responsible, given that the ratings are mere "opinions", protected under freedom of expression rights granted by the US constitution, and the ratings only assess the borrowers' solvency and not the market risk.

The rating agencies are currently regulated by a voluntary code of conduct approved in December 2004 by the International Organization of Securities Commissions (IOSCO), which must resolve any potential conflicts of interest. In the United States, the Credit Rating Agency Reform Act came into force on 26 June 2007. This Act establishes certain criteria so that rating agencies can register with the SEC as Nationally Recognized Statistical Rating Organizations (NRSRO). The new law seeks to improve the quality of ratings and increase sector competition with a greater number of NRSROs.
} 
Table 5. Long-term sovereign ratings equivalences

\begin{tabular}{|c|c|c|c|}
\hline & Standard \& Poor's & FitchRatings & Moody's \\
\hline \multirow{10}{*}{ 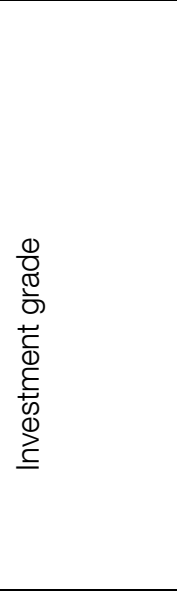 } & AAA & AAA & Aaa \\
\hline & $\mathrm{AA}+$ & $\mathrm{AA}+$ & Aa1 \\
\hline & $\mathrm{AA}$ & AA & Aa2 \\
\hline & AA- & AA- & Aa3 \\
\hline & $\mathrm{A}+$ & $\mathrm{A}+$ & A1 \\
\hline & A & A & $\mathrm{A} 2$ \\
\hline & A- & A- & A3 \\
\hline & $\mathrm{BBB}+$ & $\mathrm{BBB}+$ & Baa1 \\
\hline & BBB & BBB & Baa2 \\
\hline & BBB- & BBB- & Baa3 \\
\hline \multirow{11}{*}{ 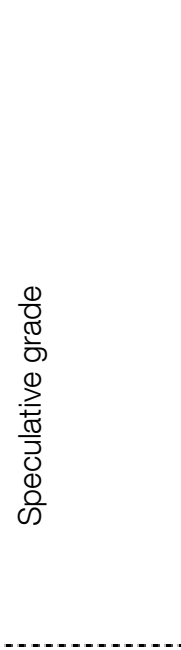 } & $\mathrm{BB}+$ & $\mathrm{BB}+$ & $\mathrm{Ba} 1$ \\
\hline & $\mathrm{BB}$ & $\mathrm{BB}$ & $\mathrm{Ba} 2$ \\
\hline & BB- & BB- & $\mathrm{Ba3}$ \\
\hline & $\mathrm{B}+$ & $\mathrm{B}+$ & B1 \\
\hline & $\mathrm{B}$ & $\mathrm{B}$ & B2 \\
\hline & $\mathrm{B}-$ & $\mathrm{B}-$ & B3 \\
\hline & $\mathrm{CCC}+$ & $\mathrm{CCC}+$ & Caa1 \\
\hline & $\mathrm{CCC}$ & $\mathrm{CCC}$ & Caa2 \\
\hline & CCC- & CCC- & Caa3 \\
\hline & $\mathrm{CC}$ & $\mathrm{CC}$ & $\mathrm{CC}$ \\
\hline & C & C & \multirow[t]{2}{*}{ C } \\
\hline Default & D & D & \\
\hline
\end{tabular}

Annexe 2 presents an updated list at 30 November 2007 of sovereign ratings issued by the three above-mentioned rating agencies. Each agency has its own key for the ratings. These keys may be summarized as follows:

$$
\begin{aligned}
& \Rightarrow \text { AAA } \\
& \text { The country has institutional strength, with commercial and financial } \\
& \text { openness and macroeconomic stability. It represents the lowest } \\
& \text { expectation of credit risk. } \\
& \Rightarrow \text { AA } \\
& \text { The country has a very high credit quality and a very low credit risk. Its } \\
& \text { economy is slightly more vulnerable to adverse external events than AAA } \\
& \text { countries. Fiscal deficits tend to be more variable, and government } \\
& \text { borrowing and external debt are generally higher. } \\
& \Rightarrow \text { A } \\
& \text { Credit quality is high and credit risk is low. Ratings for these countries are } \\
& \text { usually limited by vulnerabilities associated to their development stage, a }
\end{aligned}
$$


narrow economic base, the need for restructuring and a political situation that requires some degree of improvement.

$\Rightarrow \mathrm{BBB}$

Credit quality is good and credit risk is low. It is the lowest category of investment grade. Debt service is not as secure as in higher rating levels.

Political factors are more important than at higher rating levels. These countries typically have well-established market-oriented economic programmes. Capital markets are less developed and financial system supervision may be substandard.

$\Rightarrow \mathrm{BB}$

It is the highest speculative grade level, which reflects a significantly higher political risk that may influence economic policy. Per capita income is low and lack of economic diversity and structural shortcomings may hamper economic growth. The debt level and debt service are generally high.

$\Rightarrow \mathrm{B}$

This grade is highly speculative. Orthodox economic policies are typically found wanting. The financial sector is often weak. Debt service payment is vulnerable to adverse external influences. Fiscal deficits, inflation rates and external debt are usually high.

$\Rightarrow \mathrm{CCC}$

Default is a real possibility. There is a significant economic, and perhaps political, instability. The currency is weakening, inflation is increasing and the level of short-term debt service is high.

$\Rightarrow \mathrm{CC}$

Default is probable.

$\Rightarrow \mathrm{C}$

Default is imminent.

$\Rightarrow \mathrm{SD}$ (Selective Default)

For some financial obligations, payments have not been serviced within the applicable grace period. However the country continues to pay other debts and instruments.

$\Rightarrow \mathrm{D}$

The sovereign has defaulted on its financial obligations.

Table 6 offers a summary of the most important variables for country risk analysis purposes. 
Table 6. Variables relevant to the study of country risk

\begin{tabular}{|c|c|}
\hline \multirow[t]{5}{*}{ Political Situation } & Geopolitical risk in the region \\
\hline & Domestic and foreign political conflict risk \\
\hline & Political stability, government efficiency, institutional strength \\
\hline & Debt payment culture \\
\hline & Level of corruption \\
\hline \multirow[t]{7}{*}{ Macroeconomic Situation } & GDP growth rate, with breakdown by consumption, investment and saving \\
\hline & Inflation rate and monetary policy instruments \\
\hline & Nominal and real interest rates \\
\hline & Public sector balance (\% GDP) \\
\hline & Domestic and foreign public debt (\% GDP) \\
\hline & Size of local bond market (\% GDP) \\
\hline & Unemployment rate \\
\hline \multirow[t]{6}{*}{ Economic Structure } & GDP composition by activity sector \\
\hline & Population size \\
\hline & Income distribution, measured by the Gini index \\
\hline & Per capita income (in \$) \\
\hline & Exports of single primary good (\% of total exports) \\
\hline & Energy imports (\% of primary energy consumption) \\
\hline \multirow[t]{5}{*}{ Banking Sector } & Non performing loans (\% of total credits) \\
\hline & Solvency and profitability ratios \\
\hline & Foreign bank penetration \\
\hline & Bank foreign exchange assets and liabilities \\
\hline & Banking supervision and deposit insurance institution \\
\hline \multirow[t]{7}{*}{ External Sector } & Trade and current account balances \\
\hline & Exchange rate system and devaluation history \\
\hline & Payments record and refinancing history at Paris Club \\
\hline & Level and structure of external debt \\
\hline & Exchange controls \\
\hline & Foreign reserves and their cover of imports and short-term debt \\
\hline & Direct and portfolio foreign investment \\
\hline \multirow[t]{2}{*}{ Market Indicators } & Sovereign debt spread \\
\hline & Credit Default Swap spread \\
\hline \multirow{3}{*}{$\begin{array}{l}\text { Long-term foreign currency } \\
\text { sovereign ratings }\end{array}$} & Moody's \\
\hline & Standard \& Poor's \\
\hline & FitchRatings \\
\hline
\end{tabular}




\section{$5 \quad$ Payment crises and country risk}

\subsection{Causes of payment crises}

Financial crises affect country risk insofar as they might give rise to payment crises (default or non-payment of external debt). Clearly any country may suffer a financial or a foreign exchange crisis that inevitably leads to certain domestic adjustments. However, these crises do not imply non-payment of debt if the country holds low or sustainable levels of foreign debt, or if its currency is internationally accepted as a means of payment. In the latter case, the country does not have to resort to the foreign exchange market in order to carry out transactions with the rest of the world, since it benefits from seignorage rights, and the debt can be honoured by simply issuing domestic currency. Such is the case of the United States and, to a lesser extent, the euro zone countries, Japan, United Kingdom and Switzerland.

Leaving aside payment crises owing solely to an unwillingness to repay the debt, it may be said that all payment crises stem from an imbalance between the foreign currency supply and demand in a country's foreign exchange market, due to an excess demand for foreign currency on the existing supply. The excess demand causes either a devaluation of the domestic currency or a reduction in the country's foreign reserves -which act as buffer stock to reduce the excess currency demand - or both at once. The imbalance of the foreign exchange market may have different causes, some being strictly domestic, others having an external origin, or stemming from a combination of both internal and external factors. Typically, both internal and external factors play a role in financial crises and they are mutually reinforcing.

Amongst the domestic factors, the first to be mentioned is an excessive amount of external debt, which gives rise to debt service payments that are beyond the country's capacity to pay. External debt may be of public origin -due, for example, to the inability to finance the public deficit domestically- or of private origin -due, for instance, to an excess of foreign currency bank liabilities relative to assets. A crisis may also be stem from the premature liberalization of the capital account, leading to an excessive accumulation of nonresident bank deposits or portfolio investments, which result in an excess demand for foreign currency in the event of a sudden withdrawal of the funds invested. This withdrawal may cause a devaluation, which could in turn give rise to an external debt default due to a significant increase in the domestic value of the external debt. Political events may also trigger a confidence crisis in the country, giving rise to the withdrawal of foreign funds and the flight of domestic capital, causing the subsequent devaluation of the currency. Examples of such events are a radical party electoral victory, a coup d'état, or the outbreak of a war with a neighbouring country. In all these cases, domestic and foreign capital flight in search of safe havens prior to the crisis, or once it has broken out, is an aggravating factor, as it represents an additional source of foreign currency demand, with the resulting deepening of the foreign exchange crisis. Foreign reserves may serve wholly or partially to absorb the foreign exchange market imbalance, as they make up a source of foreign currency serving as a buffer to wipe out the excess demand. This explains why countries with sizable volumes of foreign reserves offer a lower level of country risk.

External factors may include, among others, an international confidence crisis spurred by the bursting of a financial or property bubble, a recession in one or more top-tier 
developed countries, a drop in the price of internationally traded commodities, an international armed conflict, or the contagion of a payment crisis from a neighbouring country.

\subsection{Some examples of crises}

Some financial crises which have led to external debt crises are briefly described below. It is worth noting that in some cases the default did not materialise, or did only partially, owing to prompt action by the IMF and foreign debt renegotiating schemes.

Some payment crises have had ample international consequences due to the magnitude of the financial flows affected and their potential for regional contagion ${ }^{20}$, whilst others have been of a more silent nature, with limited international repercussions, almost exclusively affecting the specific country where the crisis erupted. All of them have required a considerable adjustment effort by debtors, creditors and international bodies.

A payment crisis with a limited international significance was that suffered by the Dominican Republic in 2003, prompted by the bankruptcy of the domestic bank Baninter. This crisis required financial assistance by the IMF and external debt renegotiations with the Paris Club and the London Club. In 2001, Turkey suffered a severe financial crisis, its origin being the combination of an unsustainable public deficit, an extremely high inflation rate and an insolvent banking system. The IMF swiftly provided the necessary liquidity to prevent a collapse of the currency, whilst the government implemented a strict programme of economic adjustment, thus allowing Turkey to avert defaulting on its debt. Some countries equally affected in the past by individual payment crises were Egypt (1987, 1991), Haiti (1995), Iraq (2004), Indonesia (on numerous occasions since 1966), and the Central African Republic (on several occasions since 1981), amongst many others.

The 1982 Mexican debt crisis had notable international repercussions, leading the country to devalue its currency by $42 \%$ and to default on its debt in August that same year. This crisis basically stemmed from domestic factors, namely the substantial increase in public spending -the public deficit ratio to GDP doubled between 1977 and 1981- and the accumulation of external debt -at $\$ 21$ billion in 1981-, together with massive capital outflows.

The 1993 European Monetary System (EMS) crisis, which led to the devaluation of several European currencies and to the British pound and Italian lira exiting the system, was basically an exchange crisis, attributable to internal European factors -basically maintenance of divergent macroeconomic policies by major member countries-. The EMS crisis did not give rise to an external debt default by European countries.

The crisis in Argentina in 1994-1995, which led to massive capital outflows from the country and caused a drop in GDP in excess of $4 \%$ and an unemployment rate of $18 \%$ in 1995, was initially due to an external factor: the contagion of the 1994 Mexican crisis, this phenomenon becoming known as the "tequila effect". The reason for the contagion lay in the identification made by foreign investors of the situation in both countries: implementation of neo-liberal reforms, fixed exchange rate systems, liberalization of foreign trade and a rising current account deficit.

The 1997 Asian crisis, which initially affected Thailand, although it rapidly spread to Indonesia, Malaysia and South Korea, stemmed from internal factors, and was deepened by

20. See Chapter I of Requeijo, Jaime: "Anatomía de las Crisis Financieras", McGraw Hill, 2006. 
the markets' reaction. The root of the crisis was a combination of a fixed exchange rate with the dollar, a highly liberalized capital account and an insolvent banking system. The markets played a significant role, since the panic that ensued amongst foreign investors, reflected by massive capital outflows, turned into a self-fulfilling prophecy, which lead to a $35 \%$ drop in GDP during 1997-2002 in Thailand and Indonesia, amongst other negative consequences. The expectation of a stable exchange rate had encouraged banks and companies to run considerable dollar-denominated debts, at lower interest rates than domestic ones. It had also led foreign investors to invest in these countries' asset markets, which promised risk-free profits. The massive foreign capital inflows caused a stock market and property bubbles. When the dollar appreciated in 1995, and with it these countries' currencies, the current account deficits rose to levels considered unsustainable by investors (given the fixed exchange rate) which, coupled with an insolvent financial system, led to a withdrawal of capital and a substantial currency devaluation. The drop in the value of domestic currencies increased the local currency value of external debts on an overnight basis, causing numerous bank failures and corporate bankruptcies, as well as external private debt defaults, that required several bank refinancing agreements. Such was the case in South Korea, Thailand and Indonesia ${ }^{21}$. The latter country also required debt refinancing at the Paris Club.

The 1998 Brazilian crisis was partly due to contagion from the Russian payment crisis that year and partly due to domestic factors, notably the substantial public deficit -at $8 \%$ of GDP- that had required external funding in a significant proportion. Investors deemed the situation to be unsustainable, thus massively withdrawing funds from the country and prompting a $40 \%$ depreciation of the real. The IMF had to come to the country's rescue with a sizeable financial package (loan commitment of $\$ 18$ billion).

The crisis in Argentina in 2001 basically stemmed from inadequate policies, namely the excessive external public debt (\$72 billion at the start of 2001) and the maintenance since 1990 of a currency board, which kept the peso linked to the dollar. The appreciation of the dollar against the yen and other European currencies during 1997-2000 and the devaluation of the Brazilian real after the 1998 Brazilian crisis resulted in reduced competitiveness of the Argentine economy. The government refused to reduce public spending and tried instead to balance the public accounts by collecting tax income. This policy failed because the economy had been in recession since 1998. The government defaulted on its debt in December 2001. It abandoned the currency board and the peso was devalued by $75 \%$ against the dollar. The IMF lent the country $\$ 23$ billion, which proved insufficient to stop the crisis. Eventually the country defaulted on its private and bilateral official debt. In 2005 the Argentine government proposed a debt swap, that involved a haircut of between $65 \%$ and $75 \%$ of the value of sovereign bonds held by non-resident private investors. Argentina still owes over $\$ 19$ billion to the private bondholders who did not accept the debt swap (these account for $24 \%$ of the value of the bonds), and around $\$ 6.3$ billion to Paris Club creditors.

\subsection{Crises solutions}

5.3.1 THE INTERNATIONAL MONETARY FUND

Before the creation of the IMF, payment crises were settled by ad hoc procedures, sometimes involving the military. For example, in 1902 the sovereign debt default by the

21. Indonesia, South Korea and Thailand required refinancing of their debts with private banks at the London Club. Indonesia signed four refinancing agreements: \$3 billion in June 1998; \$3.3 billion in June 1999; \$200 million in August 1999; and \$300 million in April 2000. South Korea signed one refinancing agreement involving \$21.7 billion. Lastly, Thailand refinanced \$2 billion in June 1998. Only Indonesia required refinancing at the Paris Club. 
Venezuelan government led to a seaport blockage by warships sent to Venezuela by the German, British and Italian governments in order to force payment of the debt, which the creditors successfully achieved.

Since 1945, in a broad majority of payment crises which have involved external payment difficulties, the IMF has stepped in, firstly as lender of funds designed to make up for the lack of foreign currency, secondly as a supplier of technical advice on the best-suited policies for bringing the crisis to an end, and, thirdly, as a confidence-restoring agent on account of the aforementioned actions ${ }^{22}$. Rescue packages from bilateral creditors (central banks, for example) have also contributed significantly towards mitigating external liquidity problems, as was outlined in the section devoted to the different agents in the country risk field.

Ultimately, the adjustment effort has fallen mainly on debtor countries, although the IFls and other bilateral creditors have generally provided crucial assistance, by respectively offering significant financial flows and accepting debt restructurings and cancellations which have had to be funded, either via domestic budgets in the case of official creditors, or through the profit and loss account in the case of private banking creditors.

Debtor countries wishing to be granted assistance from the IMF have to accept the conditional nature of its loans, by implementing the associated adjustment programme, agreed by both parties. Adjustment programmes not only seek to resolve short-term balance of payments problems, but also to lay the foundations for long-term balanced growth, including the balancing of external accounts.

Programmes usually include measures for reducing inflation and the public deficit, as well as for strengthening the financial system. They also feature structural reforms, such as trade and prices deregulation and improved governance. Once the programme has been approved, the IMF releases the funds at intervals, once it is satisfied that the country is achieving the performance criteria, which are defined in a quantitative way (foreign reserves, fiscal balance, external debt) or as structural goals (social security or energy sector reforms).

Some analysts and politicians have criticized IMF financial aid to countries with payment difficulties, as they believe it entails a high level of moral hazard. Moral hazard can generally be described as the change in the behaviour of a person or organization due to the fact of being insured in the event of loss. IMF assistance involves rescuing debtor countries which have implemented inappropriate policies, and investors which have awarded financing without a correct or adequate risk assessment. Knowing that the IMF will always rescue or bail-out the losers, both parties are prone to engage in irresponsible behaviour ${ }^{23}$.

Some countries that have received balance of payments assistance from the IMF during past payment crises are Mexico (\$3.7 billion in 1982), Russia ( $\$ 4.8$ billion in 1998 , South Korea (\$60 billion in 1997 -the biggest rescue package in history-24) and Argentina (\$23 billion in 2001).

22. Some countries, such as Angola, Argentina, Cuba and North Korea, have eluded financial aid from IMF, relying on assistance from friendly countries.

23. Criticisms of IMF rescue operations were particularly vocal when the IMF granted the Russian government financial assistance worth $\$ 5$ billion during the 1998 crisis.

24. Korea repaid the loan in August 2001, three years and eight months after receiving the IMF bailout, three years earlier than scheduled. 
IMF conditionality has evolved in recent years as a response to some analysts' criticisms of its actions, particularly during the 1997 Asian crisis, as they seemingly caused an unnecessary recession in some of the affected countries. Consequently in 2002 the IMF adopted new conditionality guidelines that involved a more flexible approach in the design of adjustment programmes so as to adapt to the specific political and economic conditions of each country.

The IMF has made an invaluable contribution to the improvement of economic policies, having successfully managed in recent decades to create a culture of financial soundness in the monetary and fiscal fields, as well as convincing rulers that excesses shall be paid for sooner or later, and that markets, investors and voting citizens end up rewarding balanced policies aimed at sustainable growth in the medium and long-term.

\subsubsection{THE PARIS CLUB}

The Paris Club is a forum for restructuring official bilateral external debt. This body stands as a vital participant in all external debt payment crises and has played a significant role providing external debt relief to indebted countries since its first meeting in Paris in 1956 for the Argentine debt renegotiation. The Paris Club has no legal status and does not have any written Articles. It operates exclusively based on the will of its members and as such it is a "non-institution". Despite these legal shortcomings, creditor countries have agreed to a series of rules and principles which are scrupulously respected. The Club's operating principles can be summarized as follows:

a) Case by case decisions, depending on each debtor's situation

b) Consensus between creditor countries

c) Conditionality, guaranteed by the existence of an IMF programme, which will carry out the debt sustainability analysis

d) Solidarity, whereby creditors must renegotiate their debts at the Paris Club

e) Comparability of treatment, whereby debtors cannot grant other creditors, whether or not members of the Club, more favourable conditions than those agreed by the Paris Club.

The following countries are permanent members of the Club: Germany, Australia, Austria, Belgium, Canada, Denmark, Spain, the United States, Finland, France, Ireland, Italy, Japan, Norway, the Netherlands, the United Kingdom, Russia, Sweden and Switzerland. Countries (or territories) with the status of temporary members, depending on whether or not they are creditors in the debt rescheduling in each case, are Abu Dhabi, South Africa, Argentina, Brazil, South Korea, Israel, Kuwait, Mexico, Morocco, New Zealand, Portugal, Trinidad and Tobago and Turkey.

Paris Club debt renegotiations take place under different formulas or "terms".

$\Rightarrow$ Classic Terms

Pre-cut-off date debts ${ }^{25}$ are refinanced by extending debt interest and principal maturities by up to 10 years for amounts falling due during the consolidation period ${ }^{26}$ (normally 1 year), at market interest rates.

25. Debts rescheduled are those incurred before cut-off-date. Treatments and credits granted after this date are not subject to future rescheduling.

26. The consolidation period is the one during which the debtor country requires financial relief. Debts rescheduled are those that fall due during this period. 
$\Rightarrow$ Houston Terms (in disuse)

As above, except that expiry dates are extended up to 20 years.

$\Rightarrow$ Naples Terms

Pre-cut-off date debts are renegotiated with cancellation of $67 \%$ of the debt falling due during the consolidation period (flow treatment).

$\Rightarrow$ Cologne Terms or Highly Indebted Poor Countries (HIPC) treatment Allows cancellation of $90 \%$ of the debt incurred before 1999 (year of agreement of the HIPC initiative by G-7 countries). Cancellation is applied to debt stock (stock treatment).

$\Rightarrow$ Evian terms

Similar to Cologne terms, but applied on an ad hoc basis to countries not eligible for the HIPC initiative, and requiring a substantial debt reduction. Examples are Iraq and Nigeria.

Since its creation, the Paris Club has enabled signature of 398 external debt refinancing agreements by 83 debtor countries ${ }^{27}$. The total amount of debt restructured since 1983 is $\$ 505$ billion.

The Paris Club is currently enjoying a relatively quiet stage since, on the one hand, developing and emerging countries are generally benefiting from a stable external situation with low foreign debt and, on the other hand, many countries have "graduated" from the Paris Club, having already settled the debts they rescheduled with the Club in the 1980s and 1990s, either due to the passage of time, or by way of prepayments of rescheduled debt to Paris Club creditors. Some of the countries that have recently made prepayments to the Club are Peru, Brazil, Russia, Nigeria, Algeria, Poland, Macedonia and Gabon. Mention must also be made to full debt cancellations in the context of the HIPC Initiative. Total debt cancelled under this initiative exceeds $\$ 62.2$ billion. Countries that have already benefited from HIPC debt cancellations by official bilateral creditors are Honduras, Nicaragua, Benin, Burkina Faso, Cameroon, Chad, the Democratic Republic of the Congo, Ethiopia, Gambia, Ghana, Guinea, Guinea-Bissau, Madagascar, Malawi, Mali, Mauritania, Mozambique, Niger, Nigeria, Rwanda, Sao Tome and Principe, Senegal, Sierra Leone, Tanzania, Uganda and Zambia.

\subsubsection{THE LONDON CLUB}

The London Club is the debt restructuring forum for debt incurred with private banks. It is an informal group of private creditors, which met for the first time in London in 1976. Typically the bank to which the debtor is most indebted calls and chairs the meetings. It works in a similar way to the Paris Club, both fora being independent from each other in terms of their meetings calendar and the results of their debt renegotiations.

5.3.4 JUDICIAL SOLUTIONS

Judicial solutions have been used to settle debt crises, if only on very few occasions, by certain creditors which are not Paris Club members. Recovery of debts has been achieved

27. Countries that have refinanced their external debt throughout history at the Paris Club are Afghanistan, Albania, Algeria, Angola, Argentina, Benin, Bolivia, Bosnia-Herzegovina, Brazil, Bulgaria, Burkina Faso, Burundi, Cambodia, Cameroon, Chile, Congo, Costa Rica, Croatia, Djibouti, Egypt, El Salvador, Ecuador, Ethiopia, Russia, Gabon, Gambia, Georgia, Ghana, Grenada, Guatemala, Guinea Conakry, Equatorial Guinea, Guinea-Bissau, Guyana, Haiti, Honduras, Indonesia, Iraq, Ivory Coast, Jamaica, Jordan, Kenya, Kyrgyzstan, Liberia, Macedonia, Madagascar, Malawi, Mali, Morocco, Mauritania, Mexico, Moldova, Mozambique, Nicaragua, Niger, Nigeria, Uganda, Pakistan, Panama, Peru, Philippines, Poland, Central African Republic, Democratic Republic of Congo, Dominican Republic, Romania, Rwanda, Sao Tome and Principe, Senegal, Serbia-Montenegro, Sierra Leone, Slovenia, Somalia, Sudan, Sri Lanka, Tanzania, Chad, Togo, Trinidad and Tobago, Turkey, Ukraine, Vietnam, Yemen and Zambia. 
by sale of the unpaid debt at a discount to certain funds that specialize in purchasing debt at a discount price (distressed debt funds or vulture funds). These funds subsequently gain full payment of the debt following a ruling by a court generally located in the United States ${ }^{28}$. This practice has been emphatically condemned by the Paris Club, IFIs and NGOs in general, because it breaks the Club's principle of solidarity and comparability of treatment and, above all, because it does not consider the circumstances of the debtor country, which could require financial relief under one of the established formulas, such as the HIPC Initiative.

Two notorious cases of discounted sale of debt and a subsequent court ruling to recover it are those of Peru and Zambia. In the case of Peru, in 1996 the US hedge fund Elliott Associates acquired debt unpaid by Peru amounting to $\$ 11.8$ million. After battling in the courts for four years, it forced payment of the debt by the Peruvian government for $\$ 56$ million. In the case of Zambia, a country eligible for the HIPC initiative, the US ultimatelyowned fund Donegal International acquired Zambia's commercial debt from Romania (original creditor) for $\$ 3.28$ million, subsequently demanding before the courts from the debtor country a payment of $\$ 55$ million for the same debt. On 15 February 2007, the court ruled in favour of Donegal International, although it substantially reduced -to $\$ 15.7$ million- the figure asked of Zambia.

According to a recent IMF report, cases similar to those of Zambia and Peru are pending in court for amounts totalling $\$ 1.8$ billion, associated with external debt from countries whose populations live on less than $\$ 1$ a day. In 2006, eight such cases were brought to court. Eleven out of twenty-four countries that have benefited from debt relief under the HIPC Initiative have undergone legal action by private creditors. Courts have passed sentences ruling debt payments by these countries for a total amount close to $\$ 1$ billion.

\subsubsection{AUTONOMOUS SOLUTIONS}

Finally, it is worth mentioning "autonomous solutions", or policies applied autonomously by some countries in order to end their crisis without the protection or assistance of institutions such as the IMF or the Paris Club. A recent example of this kind of behaviour is Argentina, which rejected IMF assistance in implementing an adjustment programme following the 2001 crisis. Furthermore, in December 2005, the Argentine government drew from its foreign reserves to prepay its entire outstanding debt with this organization, amounting to $\$ 9.5$ billion, with the aim of freeing itself from the conditionality attached to the debt. This prepayment understandably stirred up protests by the international creditor community (private bondholders and Paris Club creditors ${ }^{29}$, to whom Argentina still owes enormous sums of money.

Other countries which have not turned to the IMF to find a solution to their payment crises are Cuba and North Korea. Angola, long a debt defaulter, has partially settled its debt with official bilateral creditors, a final settlement being in the offing.

28. Zambia was granted a commercial loan from Romania in 1979 in order to purchase agricultural machinery. Since the debtor could not repay the debt, in 1999 it negotiated its settlement for the sum of $\$ 3$ million with the creditor. Before the agreement was signed, Romania sold the debt to Donegal International for $\$ 3.28$ million.

29. Argentina is enjoying its fifth consecutive year of high economic growth, which could prove unsustainable because of the high rate of inflation, increased public spending and low investor confidence. These risks could leave the country in a critical situation in the event that the current upward trend of the international markets and commodities were to change. 


\section{$6 \quad$ Preventing country risk}

This section outlines the main policies which may lead to a reduction of country risk for debtors and creditors, in view of the experience and lessons learnt from crises throughout history.

\subsection{Debtors}

\subsubsection{CONTROLLING INFLATION}

A major aspect in the field of macroeconomic policies that countries must keep control of is the inflation rate and the inflationary expectations. Inflation reduces external competitiveness, and leads to currency devaluations sooner or later, which increase the cost of external debt and feed investors' lack of confidence in the country's capacity to repay its debts. Fortunately, this is a lesson that most governments have long learnt, as is reflected in present inflation rates worldwide, which typically do not exceed one digit, and in countries' monetary policies which increasingly revolve around the setting of inflation targets, that are proving effective in reducing inflation rates and inflationary expectations. The average inflation rate of developing and emerging countries in 1999-2007 was 6.2\%, down from 50.3\% in 19891998. In 2006, it was 5.3\% ${ }^{30}$.

\subsubsection{LIMITING EXTERNAL DEBT}

Limiting external debt is an obvious recommendation for country risk reduction purposes. Foreign debt has been considerably reduced in recent years. The ratio of external debt to GDP in developing and emerging countries was $25.3 \%{ }^{31}$ in 2006, down from 42\% in 1999.

External debt may be originated by the public sector, the private sector or both. Limiting public external debt requires keeping public accounts well balanced. Progress has been made in this area in recent years. In 2006 the government deficit of emerging and developing countries averaged $0.4 \%$ of GDP ${ }^{32}$, down from 3.8\% of GDP in 1999. In this field, the risks arise from the fact that most developing countries cannot finance their fiscal deficits in local currency, whether on the domestic market, which is generally underdeveloped, or on the international markets, where the domestic currency is not accepted. This explains why these countries have to incur debts in the foreign currency debt markets, with the result of external debt accumulation. For the sake of long-term sustainability of the external accounts, the debt should at least serve to fund investments which have the potential to generate foreign currency income with which to pay off the debt, such as investments in the export and infrastructure sectors, which additionally increase the country's appeal for foreign direct investments.

Where private external debt is concerned, its accumulation often occurs because of the underdevelopment of domestic credit markets, which often leads to the unavailability of the financial products required by private companies. In the case of the domestic banking sector, debt risk may arise from the mismatch of foreign currency assets and liabilities, for if the latter outweigh the former and a devaluation takes place, the bank balance will suffer,

30. IMF World Economic Outlook April 2007.

31. Ibidem.

32. Ibidem. 
especially if the foreign currency-denominated liabilities are short-term, as was the case in some Asian countries during the 1997-1998 crisis.

Limiting external debt is of the essence when the country has a currency board system $^{33}$. The Argentine crisis in 2001 led to a sudden abandoning of such a system, which deepened the payment crisis and brought about considerable losses. Countries that envisage adoption of this kind of monetary system, or of a crawling-peg system ${ }^{34}$, should do so only after an in-depth analysis of the external debt sustainability, since these monetary systems do not allow for adjustment of the exchange rate to correct external imbalances.

Country risk analysts refer to countries' inability to incur foreign debt in domestic currency as the "original $\sin ^{\prime 3}$, which lies at the root of many payment crises throughout history that stemmed from an excessive accumulation of external debt, together with devaluation episodes and the automatic increase of the debt burden ${ }^{36}$. Recipes for avoiding the problems derived from "original sin" include maintenance of a balance between public revenues and public spending, along with the development of local currency bond markets, which enable countries to reduce foreign dependence and external vulnerability. The only countries that are free of "original sin" are the issuers of the five main currencies -US dollar, euro, yen, pound sterling and Swiss franc.

The development of local financial markets is not within the reach of all countries. The main obstacle is the lack of domestic savings, which characterises poor countries with low per capita income, where the population of savers and investors in local currency financial products is scarce. Even in countries with a financial sector of an acceptable size, very often only short-term credit is available and at a considerable cost, due to inefficient banking intermediation.

In recent years, there has been a considerable degree of development of local bond markets in emerging countries. According to the $\mathrm{IMF}^{37}$, in emerging Asia corporate bond markets represented $7.1 \%$ of the GDP in 2004, up from 4.3\% in 1997. In Latin America, the corresponding percentages were $1 \%$ and $2.8 \%$. Countries which have seen a significant development of the local corporate bond market are Chile and Thailand. On the opposite side, Brazil, China and India still are a long way from the desired goals in this area.

As for sovereign local bond markets, there has also been an increase in their development in recent years. Between 1996 and 2004, the proportion of issues in local currency increased 9 percentage points, reaching as much as $82 \%$ of the total, with the associated reduction in the exchange rate risk for the issuer. The reduction in the proportion

33. A currency board is a monetary system that involves linking the domestic currency to another currency, typically a vehicle currency, using a fixed exchange rate. Countries with a currency board can only issue local currency when it is fully backed by foreign reserves. Countries that adopt this monetary system benefit from immediate price stability, although they must renounce maintenance of an autonomous monetary and exchange rate policy. This makes them extremely dependent on the economy of the chosen vehicle currency. Currently, the following countries have a currency board monetary system: Bermuda, Brunei, Bosnia, Bulgaria, Cayman Islands, Djibouti, Estonia, Falkland Islands, Faroe Islands, Gibraltar, Hong Kong, Lithuania and Macau.

34. The crawling peg is an exchange rate adjustment mechanism (appreciation or depreciation) that involves small percentage exchange rate changes over an established period.

35. The concept of "original sin" applied to financial crises was introduced by Barry Eichengreen and Ricardo Hausmann during the late 1990s, after studying the Asian crisis.

36. According to Barry Eichengreen, Ricardo Hausmann and Ugo Panizza ("Original Sin: The Pain, the Mystery, and the Road to Redemption". November 2002. Inter-American Development Bank, Washington, D.C.), solving the problems caused by "original sin" not only requires strengthening national policies and institutions but also overcoming existing obstacles to acceptance by the international financial community of a greater number of vehicle currencies.

37. IMF Global Financial Stability Report, September 2005 
of foreign currency issues was partly due to bond buy-backs, particularly Brady bonds (such were the cases of Brazil, Colombia, Venezuela and Turkey). The biggest reduction in the proportion of foreign currency debt took place in Thailand (62 percentage points), Mexico (42 percentage points) and Hungary (20 percentage points).

These developments were partly made possible through the expansion of the international investor base in recent years, which has redirected its interest towards emerging country local currency bonds. Drawing funds in local currency grants the sovereign debt issuer the advantage of transferring the foreign exchange risk to the foreign investor. Also, it is easier for the issuer to service the debt in local currency than in foreign currency. However, these transactions also carry a significant risk for the issuer, which is that of a sudden withdrawal of the foreign capital invested in response to adverse pieces of news or events, with the associated negative impact on the exchange rate and capital market valuations.

It is interesting to watch the breakdown of local credit markets by types of instrument. In 2004 the total value of outstanding bonds issued by emerging countries (sovereign bonds, bonds from financial institutions and corporate bonds) represented $38.1 \%$ of GDP, as against $140.2 \%$ in the case of developed countries. In sharp contrast, bank credit accounted for $65.2 \%$ of GDP of emerging countries, compared with $76.8 \%$ in developed countries. It follows that bond markets in emerging countries still have enormous scope for development, as opposed to bank credit markets, where the level of development is substantially closer to that of financially mature countries.

\subsubsection{IMPROVING THE EXTERNAL DEBT PROFILE}

As well as limiting the amount of external debt, indebted countries must achieve a suitable debt profile, in terms of cost and maturity. Extending maturities enables the issuer to reduce roll-over risk, or the risk of the issuer not being able to take out further loans to repay previous ones when they fall due, or the risk of doing so only at very high prices. In recent years, emerging countries have managed to extend the sovereign debt maturity period by an average of 8 years in 2001 and 13 years in 2005 ${ }^{38}$. When it comes to choosing between fixed or variable interest rates, in periods of low interest rates it is preferable to take out loans at fixed interest rates. In any case, fixed interest rates reduce uncertainty, easing debt service budgeting. Of late there has been an increase in fixed rate loans. In Latin America, in relative terms there have been a greater number of variable rate loans, whilst in Asia the reverse has been the norm, with the exception of Indonesia ${ }^{39}$.

\subsubsection{HOLDING AN ADEQUATE LEVEL OF FOREIGN RESERVES}

Holding foreign reserves serves a double purpose. In the first place, they provide central banks with a means of protecting the exchange rate from excessive volatility. Secondly, reserves are held for precautionary purposes, so as to meet foreign payments in the event that there is a temporary interruption of foreign income inflows. In the case of indebted emerging countries, holding sizeable reserves is rated favourably by the markets and rating agencies, as it is viewed as a guarantee for external debt repayment and for correction, or at least tempering, of possible speculative currency attacks. In practice, many countries use, and have used throughout history, their reserves in order to keep their exchange rate fixed or

38. IMF Global Financial Stability Report, April 2006.

39. Ibidem. 
quasi-fixed, with a view to maintaining external competitiveness. The need to hold reserves as a precaution has diminished in developed countries due to flexible exchange rates and the strength of macroeconomic policies.

It is currently thought that the optimum level of reserves should meet two conditions: cover of $100 \%$ of short-term debt (Greenspan-Guidotti rule) and cover of 3-4 months of imports. The latter condition is especially important in poor countries, which are frequently exposed to fluctuations in their export revenues and do not have access to capital markets. Reserves below the above mentioned levels may spark off investor mistrust, with the ensuing adverse effect on the debt spread and sovereign rating. Por example, in June 1997, just before the Asian crisis, South Korea held reserves amounting to just a third of its short-term external debt, compared with reserves representing 200\% of its short-term debt in 2006.

Holding large amounts of foreign reserves may also entail certain costs, namely:

$\Rightarrow$ Sterilization costs

Sterilization ${ }^{40}$ carries fiscal costs if the domestic interest rate exceeds the yield on foreign reserves. Furthermore, if debt securities have to compete with other securities in a low liquidity context, sterilization will lead to an increase in the interest rate, which will also attract additional foreign capital seeking a greater yield, leading in turn to greater sterilization needs, and so on. This spiral gives rise to what is known as the policy trilemma or impossible trinity, which states the impossibility of simultaneously maintaining fixed exchange rates and an autonomous monetary policy in the context of a liberalized capital account. Nonetheless, when liquidity is high, the economy has not reached its potential growth level and capital movements are not free, sterilization can be an effective way to achieve monetary goals ${ }^{41}$.

$\Rightarrow$ Opportunity costs

Possible alternative uses of foreign reserves may provide a higher long-term yield than placing them in short-term deposits or securities. Alternative uses include prepayment of external debt, or public spending on infrastructures, health or education.

$\Rightarrow$ Valuation costs

When foreign reserves lose value relative to the local currency (due to the latter's appreciation), the central bank will record losses on its balance sheet.

$\Rightarrow$ Other costs

If reserves give rise to a false feeling of security in the face of crises, the incentives to introduce necessary economic reforms may dwindle.

Currently, many emerging countries, led by China, Russia, South Korea, India, Brazil and Singapore, have accumulated reserves far exceeding the level required by the above mentioned criteria. In fact, many emerging countries are drawing on their foreign reserves in order to set up or enlarge their sovereign wealth funds $-S W F^{42}$ - in order to diversify their foreign currency portfolio with longer term securities that offer higher yields. Some SWFs also have the status of oil revenue stabilization funds. In total, SWFs manage funds in excess of

40. Sterilization refers to actions aimed at neutralizing the expansive monetary impact of increased reserves, by draining liquidity via the placement of public debt securities on the domestic market.

41. Modern day China is an example of a country that sterilizes a high volume of its foreign reserves increase every year (around 40-60\%) with acceptable results, due to wide acceptance of public securities by the banking system, the idle capacity in many sectors of the economy and the lack of full freedom of capital movements.

42. Sovereign wealth funds are generally defined as state-controlled investment vehicles funded by foreign-exchange assets. 
$\$ 2.5$ trillion. Some of these funds have long existed. What is new about them is the spectacular increase in their holdings and in their international portfolio. Examples of SWFs are the Petroleum Fund (Norway), China Investment Corporation (China), Abu Dhabi Investment Authority (Abu Dhabi - United Arab Emirates), Emirates Investment Authority - EIA (United Arab Emirates), Temasek Holdings and GIC (Singapore), and Kuwait Investment Authority (Kuwait). Table 8 presents the largest SWF as of 31 December 2006.

Following a recent mandate by the G-7, the IMF and the OECD are studying different approaches to the issue of SWF. The IMF is drawing a voluntary code practice for these funds, with the assistance of Norway, Singapore and Abu Dhabi, which could be shortly launched. The OECD for its part is identifying best practices for member countries that receive SWF investments, that try to avoid curtailing freedom of capital movements. The European Union Commission is also proposing a common EU approach to respond to concerns over SWFs and enhance the transparency, predictability and accountability of SWFs' investments, while maintaining an open investment environment.

Table 7. Foreign reserves ratios for some emerging countries, 2005

\begin{tabular}{|l|r|r|}
\hline & Reserves/Short-Term Debt & Reserves/ Monthly Imports \\
\hline Recommended ratios & $\mathbf{1 . 0 0}$ & $\mathbf{3 . 0 0}$ \\
\hline China & 11.58 & 15.72 \\
\hline Taiwan, prov. of China & 5.95 & 15.65 \\
\hline South Korea & 2.63 & 7.93 \\
\hline Russia & 4.43 & 16.40 \\
\hline India & 4.29 & 13.17 \\
\hline Mexico & 2.71 & 3.78 \\
\hline Malaysia & 3.09 & 7.49 \\
\hline
\end{tabular}

Source: IMF.

Table 8. Main SWFs at 31 December 2006

\begin{tabular}{|l|c|c|}
\hline Country & Year of establishment & Assets (\$billion) \\
\hline United Arab Emirates & 1976 & 688 \\
\hline Norway & 1990 & 316 \\
\hline Singapore (GIC) & 1981 & 215 \\
\hline Kuwait & 1976 & 174 \\
\hline Russia & 2004 & 122 \\
\hline Singapore (Temasek) & 1974 & 108 \\
\hline China & 2003 & 66 \\
\hline Qatar & 2005 & 50 \\
\hline Algeria & 2000 & 43 \\
\hline United States (Alaska) & 1976 & 40 \\
\hline
\end{tabular}

Sources: OECD and Peterson Institute for International Economics (August 2007) 
Some emerging countries with the ability to pay their sovereign external debt have an inadequate payment culture ${ }^{43}$. The culture of non-payment of debt is common in countries that are institutionally fragile, with imperfect democratic structures and limited rule of law, with customs and traditions that do not consider timely fulfilment of contracts as being of the essence. Furthermore, in some countries that lack a deep-rooted democratic system, governments reject the legitimacy of debts incurred by previous governments, publicly displaying non-payment of debts as a means to gain popularity.

Defaulting on external debt damages public accounts because it leads to increased sovereign debt spreads, and hampers the country's access to international capital markets.

\subsubsection{LIBERALIZING THE SHORT-TERM CAPITAL ACCOUNT IN AN ORDERLY FASHION}

The orderly liberalization of the capital account aims at preventing emerging countries from being recipients of foreign hot money before its financial institutions, foreign exchange markets and capital markets are sufficiently developed (in terms of depth and liquidity) and supervised, so as to prevent episodes of sudden capital flight from the country, which could have a disproportionate impact on the exchange rate and local financial markets, thus causing a payment crisis.

The IMF has admitted that the premature liberalization of the capital account in a large number of countries could have been linked to foreign payment crises. In April 1997, the late IMF Interim Committee ${ }^{44}$ favoured a change of the body's Articles of agreement, so as to allow it to recommend an orderly liberalization of the capital account. Eichengreen and Mussa ${ }^{45}$ have stressed the need for financial liberalization to be undertaken gradually, as the country carries out the necessary policies to limit the costs of such liberalization. These policies include prudent macroeconomic policies and appropriate financial policies, which allow for effective risk management by agents, adequate financial regulation that takes into account modern financial system demands (rules on accountancy and auditing, transparency and good governance), adequate financial system supervision and, where necessary, measures to deter short-term capital movements based, not on direct prohibitions, but on market-friendly mechanisms (such as minor taxes on short-term flows, as in Chile and Colombia).

\subsubsection{SUPERVISING BANKING SECTOR SOLVENCY}

Reference has already been made in the previous section to the need for countries to have adequate supervision systems and sound banking system regulations, with the aim of preventing confidence and panic crises amongst investors following the perception of an insolvent banking system.

43. Culture of non-payment of debt should not be mistaken with culture of late debt payment, which occurs not only in developing countries but also in some top-tier developed countries.

44. The IMF Interim Committee (abbreviation of Interim Committee of the Board of Governors on the International Monetary System) changed its name to become the International Monetary and Financial Committee (IMFC) in September 1999.

45. See Barry Eichengreen and Michael Mussa, "Capital Account Liberalization: Theoretical and Practical Aspects", IMF Occasional Paper 172. 
The 1997 Asian crisis was largely due to the insolvency of countries' financial systems. In the countries affected by the crisis, banking supervision was deficient and the guarantee and solvency ratios were less demanding than in developed countries. Moreover, in some of the countries affected by the Asian crisis, the banks selected their customers according to an opaque network of political and personal connections, and not according to objective risk profiles. For example, in Thailand non-performing loans accounted for $43 \%$ of total credit in 1997. Ten years later, they had fallen to $8 \%$ of total credit.

\subsubsection{COLLABORATING WITH IFIS TO ENSURE A SWIFT END TO CRISES}

When an external debt payment crisis has been forecast or has broken out, the most recommendable course of action for the debtor is to promptly accept protection of the international organizations, notably the IMF, which will serve as a funding source and a catalyst for other financial flows. Joint action by the IMF and the debtor government may help to prevent further negative consequences, such as a sharp devaluation or a considerable increase in debt spreads owing to investor uncertainty and panic.

In particular, collaboration with the IMF is a necessary condition for the country to be granted debt restructuring at the Paris Club. If the country is eligible for debt relief under the HIPC Initiative, gradual implementation of the IMF adjustment programmes will open the doors, at Completion Point ${ }^{46}$, to full cancellation of the country's official bilateral debt by Paris Club creditors and subsequently to cancellation of the debt owed to IFIs (IMF, World Bank and Inter-American Development Bank) through the Multilateral Debt Reduction Initiative (MDRI)

\subsubsection{DIVERSIFYING EXPORTS}

Countries where exports are concentrated in a limited number of goods and services suffer from a high degree of vulnerability to changes in the prices of these goods. When prices fall, the trade balance will deteriorate and the country may have to resort to import restrictions, which impinge on growth potential, forcing the country to require financial relief from the international community.

Countries with a high export concentration in a few products frequently hold a Stabilization Fund, which is fed, in periods of high prices, with a preset percentage of export revenues and, reversely, may be debited during periods of low prices, in order to stabilize external revenue. Setting up Stabilization Funds is highly regarded by country risk analysts and rating agencies. Some countries with Stabilization Funds are Norway, Russia, Chile, Venezuela, Oman and Kuwait.

\subsubsection{PROMOTING FOREIGN DIRECT INVESTMENT}

Foreign direct investment (FDI) does not suffer from the disadvantages of short-term volatility that characterise other capital flows. FDI enables to finance external payments by raising long term foreign liabilities with a lesser degree of liquidity and callability. Furthermore, FDI may

46. Completion Point is when the HIPC country receives most of the assistance in the framework of the Initiative, which results in the effective cancellation of the debt stock in the appropriate percentage to comply with the sustainability ratios. 
promote exports, technology transfer, job creation, and improved governance and business management techniques.

In order to attract foreign direct investments, countries should implement sound macroeconomic policies, improve infrastructures and promote a sound business climate, which requires a stable and trustworthy legal environment. Investment Promotion and Protection Agreements (IPPAs), as well as double taxation treaties, may also help to attract FDI.

\subsection{Creditors}

6.2.1 ANALYZING RISK

Creditors and investors who intend to direct lending funds to emerging countries should gather as much information as they can about the country where the debtor resides, and make decisions based on a rigorous analysis of risks. This recommendation is frequently disregarded by international creditors, as seen in past crises. The investors' "herd behaviour" has been profusely studied ${ }^{47}$ This behaviour involves making decisions based on mimic or contagion from other investors, and may lead to non-equilibrium prices and to episodes of market bubbles and crashes.

\subsubsection{USING RISK REDUCTION TECHNIQUES}

Creditors or investors in countries with a substantial level of country risk may resort to the possibilities the market offers to reduce or eliminate exposure to risk, notably financial derivatives, credit insurance, and other real or personal guarantees.

$\Rightarrow$ Credit Default Swaps are examples of financial derivatives that enable to reduce exposure to risk, as has already been mentioned in previous paragraphs.

$\Rightarrow$ In the field of credit insurance, it is necessary to highlight the role played by the ECAs as credit insurance providers. These agencies have already been discussed in previous sections of this report. In Spain, CESCE offers credit insurance for export operations and Spanish direct investments abroad. In exchange for an annual premium, CESCE commits to compensate the policyholder, often a credit institution or an investor in the case of direct investment insurance, in the event that the debtor does not honour its obligations. Depending on the level of country risk, CESCE has different cover policies. In defaulting countries, the company usually holds a closed cover policy. In the remaining countries, the cover policy will depend on the degree of political risk, the type of operation, the debtor's payment record and other elements which may affect country risk.

ECAs are not the only institutions to offer credit insurance. Various insurance companies currently offer credit insurance for political risks, as has been mentioned in previous paragraphs.

47. Robert Schiller has been an outstanding researcher of irrational behavior of investors in the financial markets. In 1981, he published an article in the American Economic Review entitled "Do stock prices move too much to be justified by subsequent changes in dividends?", in which he challenged the theory of efficient markets. More recently (2000), he published a book entitled "Irrational Exuberance", which was a best-seller, on the technology bubble during the late 1990s. 
$\Rightarrow$ Other guarantees that are on offer to reduce country risk include those provided by structured operations that involve implicit guarantees. An example of a structured operation is that in which the borrower guarantees the creditor repayment of the debt by funding an escrow account ${ }^{48}$ with the proceeds of a supply contract (an oil supply contract, for example) between the debtor and a third party. The amounts deposited in the escrow account will serve as a debt servicing guarantee for the original debt contract.

\subsubsection{ENHANCING COLLABORATION BETWEEN DEBTORS AND CREDITORS}

The creditors may wish to include clauses allowing for the renegotiation or restructuring of debt in the bond issue contract in case the debtor should experience payment difficulties before maturity. Collective action clauses $(C A C)^{49}$ were introduced in international emerging market bond contracts under New York law in March 2003, when Mexico issued a \$1 billion bond $^{50}$. CACs enable restructuring of debt if agreed by a vast majority of creditors, to address potential free rider problems. These clauses also set out collaborating procedures between creditors and debtors in the event of restructuring. All but two sovereign bonds issued under New York jurisdiction since 2003 have included CACs in their issue contract. At 23 January 2006, $57 \%$ of outstanding sovereign bonds from emerging countries included CACs.

A second market option for facilitating collaboration between creditors and debtors is the November 2004 Institute of International Finance (IIF) ${ }^{51}$ proposal on Principles for Stable Capital Flows and Fair Debt Restructuring in Emerging Markets, to which 30 emerging countries (including Brazil, Korea, Philippines, Indonesia, Morocco, Mexico, Peru, Dominican Republic and Turkey) as well as distinguished members of the IIF and the ICMA (International Capital Market Association) have already adhered. The IMF, G-7 and G-20 have also shown their support for the Principles. These were drawn up to complement rather than substitute CACs, and were set up as a joint proposal by some major international sovereign debt issuers (Brazil, South Korea, Mexico and Turkey) and renowned private credit institutions.

The proposal consists of a framework for mutual collaboration between debtors and creditors, with the aim of preventing payment crises and, in that event, being able to address them in the most effective manner so as to minimize their duration and the damage caused.

Collaboration between debtors and creditors provided for in the Principles focuses on four areas:

$$
\begin{aligned}
& \Rightarrow \text { Transparency and timely flow of information } \\
& \Rightarrow \text { Close debtor-creditor dialogue and cooperation to avoid restructuring } \\
& \Rightarrow \text { Good faith actions } \\
& \Rightarrow \text { Fair treatment. }
\end{aligned}
$$

\footnotetext{
48. An escrow account, (sometimes also known as a trust account or a sequestered account) stems from an agreement between the account holder and his escrow agent, whereby the account holder transfers funds or assets to the said account, which may only be debited to pay specific debts between the account holder and a third economic agent, once the escrow agent is satisfied that certain conditions have been fulfilled.

49. See Requeijo, Jaime (2006): "Anatomía de las crisis financieras”, McGraw Hill, 2006.

50. See IIF, March 2005, Principles for Stable Capital Flows and Fair Debt Restructuring in Emerging Markets.

51. IIF is a global private association of national and international financial institutions, although large multinational companies, ECAs and multilateral organizations may also become members. It was set up in 1983 in the aftermath of the Latin American debt crisis. The goal of IIF is to support the financial industry in sound risk management, including sovereign debt, in the development of good practices and standards, in the defense of economic, financial and regulatory policies which promote global financial stability, and attend to the interests of its members.
} 
Two bodies are responsible for managing actions to promote the acceptance of the Principles:

$\Rightarrow$ The Principles Consultative Group, where both issuers and investors participate. It meets every quarter to evaluate application of the Principles.

$\Rightarrow$ The Group of Trustees, which provides guidance for the implementation of the Principles. It comprises a mixture of senior civil servants from emerging countries and senior managers from private finance. The joint presidents of this group are Jean-Claude Trichet (President of the European Central Bank), Henrique Meirelles, (President of the Central Bank of Brazil), and Toyoo Gyohten (President of the Institute for International Monetary Affairs in Tokyo, a former Japanese Vice Minister of Finance and a former Chairman of the Bank of Tokyo). 


\section{Assessment of country risk in the world today}

\subsection{Global outlook}

For some years, the international economy has enjoyed a period of unprecedented prosperity. All the liquidity and solvency indicators have shown improvements and country risk has been reduced in virtually all regions of the world. Nevertheless, the financial turmoil of August and September 2007, as well as other risks to the downside, could slow the trend of expansion and spoil the current favourable outlook. This section will cover the global economic situation, with mention of the factors that lie behind recent developments. Also it will outline the risks that may be a matter for concern.

\subsubsection{GLOBAL ECONOMIC CONDITIONS AND COUNTRY RISK}

Tables 9 and 10 show that the global economy has been enjoying a period of expansion, with forecast growth of $5.2 \%$ in 2007 , accompanied by low inflation and interest rates, as well as substantial growth in world trade. Economic growth has been particularly marked in emerging and developing countries, where it is expected to reach rates of $8.1 \%$ in 2007 and $7.4 \%$ in 2008, according to recent IMF projections ${ }^{52}$.

Table 9. Trade, commodity prices, inflation and interest rates

\begin{tabular}{|l|r|r|r|r|}
\hline & 2005 & 2006 & $2007^{a}$ & $2008^{a}$ \\
\cline { 2 - 5 } & \multicolumn{3}{|c|}{ (annual percent change) } \\
\cline { 2 - 5 } World trade volume (goods and services) & 7.5 & 9.2 & 6.6 & 6.7 \\
\hline Oil prices $^{*}$ & 41.3 & 20.5 & 6.6 & 9.5 \\
\hline Non-oil commodity prices & 10.3 & 28.4 & 12.2 & -6.7 \\
\hline Inflation in developed countries & 2.3 & 2.3 & 2.1 & 2.0 \\
\hline $\begin{array}{l}\text { Inflation in emerging and developing } \\
\text { countries }\end{array}$ & 5.2 & & 5.9 & 5.3 \\
\hline
\end{tabular}

Source: IMF. World Economic Outlook, October 2007.

(a) Estimates

* Simple average spot price of Brent, Dubai, and West Texas Intermediate (WTI) crude oil.

** Global average, weighted by global exports. 
Table 10. World economic growth forecasts (annual percent change)

\begin{tabular}{|c|c|c|c|c|}
\hline & 2005 & 2006 & $2007^{\mathrm{a}}$ & $2008^{\mathrm{a}}$ \\
\hline World & 4.8 & 5.4 & 5.2 & 4.8 \\
\hline Developed countries & 2.5 & 2.9 & 2.5 & 2.2 \\
\hline United States & 3.1 & 2.9 & 1.9 & 1.9 \\
\hline Euro area & 1.5 & 2.8 & 2.5 & 2.1 \\
\hline Germany & 0.8 & 2.9 & 2.4 & 2.0 \\
\hline France & 1.7 & 2.0 & 1.9 & 2.0 \\
\hline Italy & 0.1 & 1.9 & 1.7 & 1.3 \\
\hline Spain & 3.6 & 3.9 & 3.7 & 2.7 \\
\hline Japan & 1.9 & 2.2 & 2.0 & 1.7 \\
\hline United Kingdom & 1.8 & 2.8 & 3.1 & 2.3 \\
\hline Canada & 3.1 & 2.8 & 2.5 & 2.3 \\
\hline Other developed countries & 3.9 & 4.4 & 4.3 & 3.8 \\
\hline Developed Asian countries & 4.7 & 5.3 & 4.9 & 4.4 \\
\hline $\begin{array}{l}\text { Emerging and developing } \\
\text { countries }\end{array}$ & 7.5 & 8.1 & 8.1 & 7.4 \\
\hline Africa & 5.6 & 5.6 & 5.7 & 6.5 \\
\hline Sub-Saharan Africa & 6.0 & 5.7 & 6.1 & 6.8 \\
\hline Central and Eastern Europe & 5.6 & 6.3 & 5.8 & 5.2 \\
\hline $\mathrm{ClS}^{*}$ & 6.6 & 7.7 & 7.8 & 7.0 \\
\hline Russia & 6.4 & 6.7 & 7.0 & 6.5 \\
\hline CIS excluding Russia & 6.9 & 9.8 & 9.4 & 8.1 \\
\hline Developing Asian countries & 9.2 & 9.8 & 9.9 & 8.8 \\
\hline China & 10.4 & 11.1 & 11.5 & 10.0 \\
\hline India & 9.0 & 9.7 & 8.9 & 8.4 \\
\hline Middle East & 5.4 & 5.6 & 5.9 & 5.9 \\
\hline Western Hemisphere & 4.6 & 5.5 & 5.0 & 4.3 \\
\hline Brazil & 2.9 & 3.7 & 4.4 & 4.0 \\
\hline Mexico & 2.8 & 4.8 & 2.9 & 3.0 \\
\hline
\end{tabular}

Source: IMF. World Economic Outlook, October 2007.

(a) Estimates.

${ }^{*}$ Commonwealth of Independent States (Russia and countries of the former USSR).

Table 11 shows some relevant country risk indicators for developing and emerging countries in 1999 and 2006, including macroeconomic indicators (growth, inflation, fiscal balance and current account balance), commodity prices, external debt and solvency indicators. There has been a general improvement during the eight-year period for all of the indicators displayed. Fiscal and current account balances have improved, inflation has been reduced and economic growth has increased substantially. Non debt-generating flows (basically direct investment) have increased their relative share in total liabilities, as has financing from banks and other private creditors (basically bondholders). Meanwhile, both bilateral and multilateral official creditor financing has dropped substantially, due to recent 
debt prepayments. Sovereign financing represented less than a third of total financing in April 2007 , compared to figures in excess of $50 \%$ during the period 1998-200553. These developments were underpinned by the increase in private corporate issues as a result of the liquidity boom, the rebalancing of public accounts and greater public sector funding in the domestic bond market. At the same time, annual change (in absolute terms) in official foreign reserves reached the unprecedented figure of $\$ 612$ billion at end-2006, partly because the countries with external surplus opted to accumulate reserves, whilst other policies, such as full liberalization of the capital account or further flexibility of the exchange rate system, were carried out to a lesser extent.

Table 11. Some country risk indicators for developing and emerging markets. 1999 and 2006.

\begin{tabular}{|c|c|c|}
\hline & 1999 & 2006 \\
\hline Real GDP growth (\%) & 4.1 & 7.9 \\
\hline Inflation rate (\%) & 10.3 & 5.3 \\
\hline Central government fiscal balance ${ }^{a}$ & -3.8 & -0.4 \\
\hline Commodity prices ${ }^{b}$ & -7.2 & 28.4 \\
\hline Current account balance ${ }^{c}$ & -21.2 & 544.2 \\
\hline Net external finance ${ }^{\complement}$ of which: & 230.7 & 785.5 \\
\hline Non external debt-generating ${ }^{d}$ & 184.8 & 491.0 \\
\hline External debt-generatinge & 45.9 & 294.5 \\
\hline Official creditors ${ }^{c}$ & 34.5 & -64.5 \\
\hline $\mathrm{IMF}^{\mathrm{c}}$ & -2.4 & -30.1 \\
\hline Banks $^{c}$ & -13.0 & 57.8 \\
\hline Other private creditors ${ }^{c}$ & 24.3 & 301.2 \\
\hline Total external debt ${ }^{c}$ & $2,453.0$ & $3,242.9$ \\
\hline External debt to GDP ratio (\%) & 42.0 & 26.3 \\
\hline Debt service to exports ratio (\%) & 8.7 & 4.4 \\
\hline Foreign reserves in annual change ${ }^{c}$ & 81.0 & 612.0 \\
\hline
\end{tabular}

Source: IMF. World Economic Outlook. April 2007.
(a) Percentage of GDP.
(b) Annual percent change, excluding oil.
(c) Billion \$.
(d) Foreign direct investment and capital transfers, in \$billion.
(e) Medium and long term loans and bonds, in \$billion.

In short, country risk has fallen in emerging and developing markets in recent years, supported by the buoyancy of the real economy, which was driven by swift economic expansion in the BRICs (Brazil, Russia, India and China). The growth was combined with

53. IMF, Global Financial Stability Report, April 2007. 
unprecedented abundant liquidity ${ }^{54}$, which up to June 2007 had seen emerging sovereign debt spreads fall to record lows (the EMBI+ closed at 149 basis points on 1 June 2007, down from 418 basis points on 31 December 2003). Spreads have rebounded somewhat since then, as a result of the financial turbulence that hit the markets during July and August 2007 (the $\mathrm{EMBI}+$ stood at 246 basis points on November 30, 2007).

Another reflection of the reduction of country risk in emerging countries was the improvement of long-term foreign currency sovereign debt ratings by rating agencies, which have carried out a significantly higher number of upgrades than downgrades in the last five years. In 2006, improvements in ratings accounted for $72.7 \%$ of total rating changes that year, while downgrades only accounted for $12.9 \%$ of total changes. During the first eleven months of 2007, the three main agencies produced 59 rating changes, of which 50 were improvements and 9 were downgrades ${ }^{55}$. In the short term, upgrades will continue to exceed downgrades, given that the number of countries with a positive outlook exceeded the number of countries with a negative outlook by a factor of $4.8^{56}$.

Two reasons may explain the improved country risk indicators for emerging countries. Firstly, their macroeconomic performance and fundamentals have improved dramatically, namely the growth rate, the current account balance, the foreign reserves, the ratio of external debt to exports and the ratio of public debt to GDP. These improvements stem both from the implementation of prudent macroeconomic and financial policies (fiscal, monetary and external debt management policies) and the positive drive exerted by the economic expansion of many countries, including China, which has also lain behind the international commodity price increases. Secondly, emerging countries have benefited from abundant international liquidity, pushed by the recycling of current account surplus balances by China, Russia and Persian Gulf countries, underpinned in the two latter regions by the higher oil prices since 2003. The expansion of the international investor base has also played a significant role, via the development of institutional investors such as, notably, pension funds ${ }^{57}$, and, to a lesser extent, insurance companies and hedge funds. Lower interest rates attributable to the placement of surpluses on the financial markets has led to lower risk aversion, the most visible sign being the spread compression for the riskiest assets. The search for yield by international portfolio managers has played a paramount role in lowering risk aversion. A reflection of the improved country risk indicators of emerging and developing countries is the higher status gained by private creditors in the field of emerging countries

54. Liquidity is the ease with which an asset can be changed for money without suffering a loss. There are three ways of looking at liquidity: the general monetary conditions (monetary supply, official interest rates and credit price); the proportion of liquid assets in company's balances; and the liquidity of the financial markets, that is, the ease with which securities can be bought and sold without causing significant price changes. Some analysts measure liquidity by the demand for high risk assets. The greater the demand, the greater the level of liquidity.

55. The first eleven months of 2007 saw improved ratings for Poland, Oman (Moody's and S\&P), India, Azerbaijan, Belize (Moody's and S\&P), Cameroon, Colombia, Qatar (Moody's and S\&P), Malawi, Montenegro, Poland, Japan, Brazil (S\&P and Fitch), Paraguay, Colombia, South Korea, China (Moody's and S\&P), Hong Kong (Moody's and FitchRatings), Macao, Uruguay, United Arab Emirates, Cyprus, Malta, Saudi Arabia (Moody's and S\&P), Kuwait (Moody's and S\&P), Peru, Bahrain (Moody's and Fitch), Granada, Dominican Republic (Moody's and S\&P), Papua New Guinea, Mexico (S\&P and Fitch), Czech Republic, Indonesia, Surinam, Israel, Ecuador, Andean Development Corporation and CentralAmerican Bank of Economic Integration (S\&P). Of the nine downgrades, three applied to Ecuador, whose rating was lowered by the three main agencies in January, and the others applied to Iceland, Fiji, Grenada, Latvia (S\&P and Fitch), and Kazakhstan.

56. The rating outlook can be positive, negative or stable, and represents an opinion on the direction of a possible medium-term rating change (normally one or two years).

57. Pension funds generally invest on a long-term basis (buy-and-hold). Roughly $40 \%-50 \%$ of their assets are invested in sovereign debt. 
external debt. In 2006, official creditors (bilateral and multilateral) accounted for $24 \%$ of total debt, down from $37.6 \%$ in 199958 .

The diagram below helps to clarify the reasons for the improvement of country risk in emerging and developing countries:

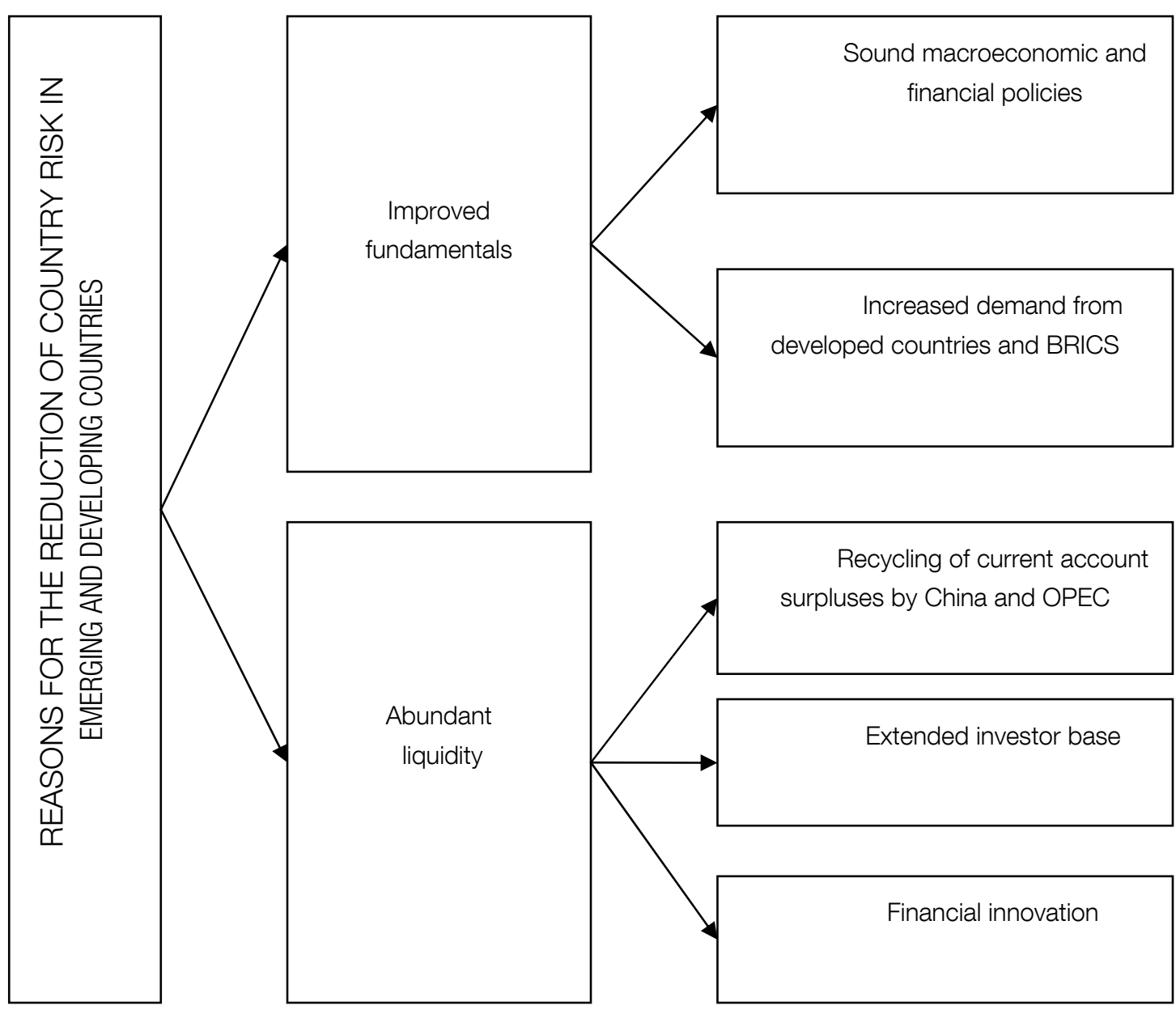

\subsubsection{EXISTING SHORT AND MEDIUM-TERM RISKS TO THE OUTLOOK}

Global growth is expected to be buoyant in the medium term, although it is projected to slow in 2008 due to the financial turbulence caused by troubles in the housing sector in the United States. According the IMF and other global analysts, growth in the United States is expected to slow, some of them even citing recession as a potential risk. Other risks, not specifically associated with the recent financial turbulence, are relatively small, although of great potential impact. All of these risks can be summarized as follows:

a) Recession in the US economy due to the housing crisis

The increased mortgage delinquencies and foreclosures amongst subprime borrowers in the United States since end-2006, attributable to the rise in interest

58. See IMF World Economic Outlook April 2007. 
rates, triggered the confidence and liquidity crisis which hit the financial markets during August 2007.

High-risk mortgages represent just over $6.8 \%$ of all US mortgages with adjustable interest rates, which explains why the impact of the subprime crisis should in theory have only a limited effect on the US economy as a whole ${ }^{59}$. However, uncertainty surrounding location of risks, partly due to the widely adopted "originate and distribute" business model by international banks in recent years, has led to a confidence and liquidity crisis, which, if protracted, could result in a solvency crisis and have a dampening impact on US consumer and investment markets. Several investment and commercial banks worldwide have already suffered significant losses $^{60}$, and more problems could still be in the offing. In fact, troubles in the housing sector are proving higher than previously expected, and credit disruption, especially in the interbank and commercial paper markets, could have a further negative impact, compounded by increased volatility and a global reduction of market liquidity.

The IMF has cut the global growth projections for 2008 it made in April 2007 by four tenths of a percentage point (six tenths in the case of developed countries and two tenths in the case of emerging and developing countries).

Although emerging and developing countries fared well during the financial storm, and are expected to provide the basis for solid growth in 2008, they have seen a widening of sovereign spreads (notably Venezuela and Argentina) and a scaling back of capital flows. Also they could be hit by a lower demand from the United States, in the absence of a complete decoupling of their economies from the hitherto engine of the world economy. According to the $\mathrm{IMF}^{61}$, in past crises each percentage point of reduction in US GDP led on average to half of a percentage point reduction in the rest of the world GDP.

b) Inflation risk

Inflation risks raise the likelihood of central banks increasing the price of money, with the associated damage to economic activity. In the United States, although core inflation remains above the non-explicit goals of the Federal Reserve, the recent financial turbulence has eased both inflation risks and money tightening risks. Oil and food prices have contributed to increased inflation pressures in many emerging countries, especially those with a greater weight of food prices in the consumer price index. Higher food prices have been the result of pressure from increasing use of corn, and other food products for biofuel production ${ }^{62}$.

c) Higher than expected rises in oil prices due to supply and refining capacity constraints

The rise in oil prices owes both to an increase in demand (notably from China, which accounted for $72 \%$ of the increase in global oil demand in $2006^{63}$ ) and to supply constraints, due to declining production in some non-OPEC countries, compounded

59. The total value of subprime mortgages accounts roughly for $20 \%$ of total mortgages in the United States.

60. Total losses to financial institutions stemming from the subprime crisis could total $\$ 300$ billion, according to the OECD. Other analysts, like UBS, estimate losses could reach $\$ 480$ billion.

61. See IMF World Economic Outlook. April 2007.

62. In China, for example, food represents one third of the consumer price index. Food price rises in this country can be largely explained by the price increase of pork, due to pork disease and a lower production responding to lower prices the previous year.

63. See BP Statistical Review of World Energy June 2007 
by geopolitical tensions in Iran and Nigeria, and a clearly inadequate global refining capacity. These developments are all in place against the backdrop of the commitment by OPEC to reduce production as it sees fit in the event of price weakness.

The International Energy Agency (IEA) has projected an energy demand increase of $2.2 \%$ each year for the next five years, and a supply of oil and natural gas that is unlikely to meet demand without prices escalating ${ }^{64}$. In mature areas, such as the North Sea and Mexico, supply is falling at a quicker than expected rate, whilst project implementation in new areas, such as the Russian Far East, will suffer significant delays. As for the effect of conflicts in oil-producing areas, the IEA estimates that the barrel price would increase by $\$ 5$ for every million barrels per day removed from the market.

d) Disorderly adjustment of global current account imbalances

Global external imbalances (namely US current account deficit and surpluses in China, Japan and OPEC) remain a downside risk for the global economy given the uncertainty about their long-term financing, the risk of a sudden adjustment on an international scale that could serve to settle the imbalances, and the surge of claims for protectionism in countries with a current account deficit. Therefore, although there is a continuing debate about the causes underlying the imbalances, there is a broad consensus about its non sustainability in the long-term and the need to rebalance accounts in an orderly way ${ }^{65}$.

The persistence of external imbalances convinced IMF directors of the need for consensual action to help resolve these imbalances on a voluntary basis. The result was the creation of a new debate forum, known as the Multilateral Consultation on Global Imbalances (MCGI). The MCGI, which in principle includes China, the Euro area, Japan, Saudi Arabia and the United States ${ }^{66}$, was endorsed at the ministerial level by the IMF International Monetary and Financial Committee (IMFC) in April $2006^{67}$.

The risk of disorderly adjustment of external imbalances has lessened during the last year given lower growth in the US economy and the US dollar depreciation, which is helping to achieve a more balanced growth, with the current account deficit at 5,5\% of GDP, down from more than 7\% two years ago. These developments could boost the country's savings rate, which should help to resolve the imbalances, especially if lower savings rates in other countries, notably China, were achieved.

\footnotetext{
64. See International Energy Agency. World Energy Outlook 2006.

65. In its September 2007 Trade and Development Report, UNCTAD notes the paradox of real interest rates evolving in the wrong direction as a result of the "carry trade" (incurring debt in a currency with low interest and investing the borrowed sums in a currency with high interest, particularly with currencies like the yen -low interest- and the Hungarian Forint -high interest). The paradox lies in the fact that the currencies of countries with high current account deficits have appreciated whilst the currencies of countries with high current account surpluses have weakened, which has deepened external imbalances.

66. In order to be included in the MCGI group, selected regions and countries had to fulfill one or both of the following criteria: record a large external imbalance or represent a considerable proportion of world GDP.

67. According to the IMFC, the MCGI proposals had to include promoting domestic savings and fiscal balance in the US, carrying out structural reforms in Europe and Japan, promoting domestic demand and flexibilization of exchange rates in emerging Asia and, lastly, boosting domestic demand in oil-producing countries. The results of the first MCG meeting were presented to the IMFC in April 2007, and involved a statement by each MCGI member on the policies undertaken to correct the imbalances. No further MCGI meetings have been held thereafter.
} 


\subsection{Analysis by region and country}

The following paragraphs include an overview of country risk by regions and countries, underlining strengths and weaknesses for each region or country.

\subsubsection{LATIN AMERICA}

Latin America is enjoying its fourth consecutive year of high economic growth $5 \%$ on average) buoyed by domestic demand strength and the rise in commodity prices. For the first time growth is accompanied by current account surpluses, as Table 12 shows. The only countries with a current account deficit are Mexico, Colombia and Uruguay. Economic policies have improved considerably, highlighting fiscal and monetary prudence. Inflation rates are low, on a single digit range in all countries, except Argentina and Venezuela, with an average rate of $5.4 \%$ in 2006 , down from $16 \%$ in 2002. In the fiscal area, countries are recording an average primary surplus of roughly $4 \%$ of GDP. Mention must also be made of external debt reduction, due to prepayments and improvements to its structure, made possible by an appropriate external debt management. International reserves are at record highs, protecting countries from external shocks and changes in commodity prices. External debt reduction, accumulation of foreign reserves and pursuit of more flexible foreign exchange policies have led to a substantial decrease of financial vulnerability. The banking sector, which has recorded a considerable credit expansion buoyed by lower interest rates and increased savings, has seen substantial strengthening thanks to appropriate macroeconomic policies and improved banking supervision.

The region's prospects are good, although its weaknesses may stand in the way of continued prosperity, especially if the governments give in to the temptation of populist policies, which could reverse the improvements in macroeconomic imbalances. Currently, only Chile and Mexico enjoy investment grade from the three main rating agencies. El Salvador is rated as investment grade from Moody's, and Trinidad and Tobago is rated as investment grade from Moody's and S\&P.

Table 12. Latin America: GDP, inflation and current account balance

\begin{tabular}{|c|c|c|c|c|c|c|c|c|c|c|c|c|}
\hline & \multicolumn{4}{|c|}{ Real GDP* } & \multicolumn{4}{|c|}{ Inflation* } & \multicolumn{4}{|c|}{ Current account balance } \\
\hline & 2005 & 2006 & 2007 & 2008 & 2005 & 2006 & 2007 & 2008 & 2005 & 2006 & 2007 & 2008 \\
\hline Latin America & 4.6 & 5.5 & 5.0 & 4.3 & 6.3 & 5.4 & 5.3 & 5.8 & 1.4 & 1.5 & 0.6 & - \\
\hline $\begin{array}{c}\text { South America- } \\
\text { Mexico }\end{array}$ & 4.5 & 5.4 & 4.9 & 4.2 & 6.2 & 5.2 & 5.2 & 5.8 & 1.7 & 1.8 & 0.8 & 0.2 \\
\hline Argentina & 9.2 & 8.5 & 7.5 & 5.5 & 9.6 & 10.9 & 9.5 & 12.6 & 1.9 & 2.5 & 0.9 & 0.4 \\
\hline Brazil & 2.9 & 3.7 & 4.4 & 4.0 & 6.9 & 4.2 & 3.6 & 3.9 & 1.6 & 1.2 & 0.8 & 0.3 \\
\hline Chile & 5.7 & 4.0 & 5.9 & 5.0 & 3.1 & 3.4 & 3.9 & 4.1 & 1.1 & 3.6 & 3.7 & 2.3 \\
\hline Colombia & 4.7 & 6.8 & 6.6 & 4.8 & 5.0 & 4.3 & 5.5 & 4.6 & -1.5 & -2.1 & -3.9 & -3.5 \\
\hline Ecuador & 6.0 & 3.9 & 2.7 & 3.4 & 2.1 & 3.3 & 2.1 & 2.3 & 0.8 & 3.6 & 2.4 & 2.5 \\
\hline Mexico & 2.8 & 4.8 & 2.9 & 3.0 & 4.0 & 3.6 & 3.9 & 4.2 & -0.6 & -0.3 & -0.7 & -1.1 \\
\hline Peru & 6.7 & 7.6 & 7.0 & 6.0 & 1.6 & 2.0 & 1.5 & 2.3 & 1.4 & 2.8 & 1.3 & 1.1 \\
\hline Uruguay & 6.6 & 7.0 & 5.2 & 3.8 & 4.7 & 6.4 & 8.0 & 6.8 & - & -2.4 & -2.8 & -2.8 \\
\hline Venezuela & 10.3 & 10.3 & 8.0 & 6.0 & 16.0 & 13.7 & 18.0 & 19.0 & 17.8 & 15.0 & 7.8 & 4.1 \\
\hline Central America & 4.5 & 5.9 & 5.4 & 4.9 & 8.4 & 7.0 & 6.6 & 6.0 & -5.1 & -5.0 & -5.6 & -5.8 \\
\hline Caribbean & 6.5 & 8.4 & 6.0 & 4.4 & 6.7 & 8.0 & 6.4 & 5.3 & -0.3 & -0.4 & -1.0 & -0.6 \\
\hline
\end{tabular}

Source: IMF. World Economic Outlook, October 2007.

* Annual percent change

${ }^{* *}$ Percentage of GDP

Data for 2007 and 2008 are estimates.

South America-Mexico includes Bolivia and Paraguay.

Central America excludes Mexico. 
Four main weaknesses can be identified in the region: dependence on commodity prices (which could lead to recession in the event that prices enter a downward cycle), low labour productivity relative to Asia (in both industry and services), poverty, social inequality, and political instability. Although on a significantly decreasing trend, poverty continues to affect countries in the region, as illustrated by the fact that over $8 \%$ of the population lives on less than $\$ 1$ per day ${ }^{68}$. The middle class is small in many countries, and the region suffers from a notable inequality in income distribution, with reduced social mobility. This gives rise in some cases to social and political instability and explains the periodic winning of elections by populist governments, which can be a setback for the countries' economic development, and a deterrent for foreign direct investments. These governments are currently present in a minority of countries. Of all twelve presidential elections held during the period November 2005-December 2006, populist candidates won in only four countries. The rest is presently governed by moderate centre-left or centre-right governments, which represent a comfortable majority of the Latin American region's population.

According to the OECD country risk classification (Table 13), Latin American countries with the highest level of country risk are Argentina ${ }^{69}$, Bolivia, Cuba ${ }^{70}$, Ecuador ${ }^{71}$, Haiti and Nicaragua. Countries with a very high level of risk are Honduras, Jamaica, Paraguay and Venezuela. The countries with the lowest risk in the region are Chile, Mexico and Trinidad and Tobago. The median score for all of Latin American countries (31 countries) is Group 5.

68.See Global Economic Prospects 2006: Economic Implications of Remittances and Migration. World Bank.

69. Since the 2001 crisis, Argentina has failed to settle the unpaid external debt with Paris Club creditors and private bondholders who refused to accept the debt swap proposed by the government in 2005, despite having ample capacity to pay, with foreign reserves exceeding $\$ 40$ billion.

70. Cuba has accumulated large amounts of unpaid external debt with ECAs. The bulk of the debt was incurred during the early 1990s, following the interruption of foreign aid inflows from the former Soviet Union

71. The government of Rafael Correa of Ecuador, which like Argentina has the ability to pay its debt, has repeatedly threatened to default on its debt, with the resulting sovereign debt spread rises. 
Table 13. Latin America: OECD Country Risk Classification, November 2007

\begin{tabular}{|c|c|}
\hline COUNTRY & RISK CLASSIFICATION \\
\hline Argentina & 7 \\
\hline Bolivia & 7 \\
\hline Cuba & 7 \\
\hline Ecuador & 7 \\
\hline Haiti & 7 \\
\hline Nicaragua & 7 \\
\hline Honduras & 6 \\
\hline Jamaica & 6 \\
\hline Paraguay & 6 \\
\hline Venezuela & 6 \\
\hline Guatemala & 5 \\
\hline Dominican Republic & 5 \\
\hline Colombia & 4 \\
\hline El Salvador & 4 \\
\hline Peru & 4 \\
\hline Uruguay & 4 \\
\hline Brazil & 3 \\
\hline Panama & 3 \\
\hline Chile & 2 \\
\hline Mexico & 2 \\
\hline Trinidad and Tobago & 2 \\
\hline
\end{tabular}

Source: OECD

7.2.2 EMERGING ASIA

Since the Asian crisis, economies in the region have recovered considerably, thanks to IMF financial assistance and to high savings rates that have enabled to finance investments. Furthermore, significant reforms have been implemented in the banking and financial sectors. The countries' external solvency has improved and they are less vulnerable to payment crises than they were ten years ago. All the countries have a current account surplus, except India and Pakistan, less external debt and more foreign reserves, which now exceed \$2.5 trillion. China accounts for half of this figure. Overall economic growth has been strong since 2001, with a rate exceeding 8\% between 2003 and 2005. In 2006 it stood at 9,3\% and is projected to remain strong in 2007 and 2008 (see Table 14). However, growth is dominated by China and India. In China, expansion has been led by investment and exports. In India, economic growth is supported by consumer markets, investment and the external sector. In the remaining countries, growth has been mediocre. Inflationary pressures are generally contained, although they represent a certain threat in China and India, where the monetary authorities have had to adopt certain restraining measures in order to reduce excess demand 
in some sectors. The overall current account surplus increased by one percentage point, reaching $5.4 \%$ of GDP in 2006, the bulk being attributable to China. The region has received considerable amounts of foreign investment, particularly China, although these flows have jeopardised inflation control in countries with fixed exchange rates.

The region's prospects are generally favourable, although reduced global demand for Asian exports, particularly electronic goods, could affect growth adversely. Increasing inequality, as reflected in the deterioration of the Gini index in many countries in the region, particularly China, the Philippines, Singapore and South Korea ${ }^{72}$, represents another area of potential social and political instability. In emerging Asia, countries that enjoy investment grade from the three rating agencies are China, South Korea, Hong Kong, India, Malaysia, Singapore, Thailand and Taiwan. Macau has investment grade from Moody's.

Table 14. Emerging Asia: GDP, inflation and current account balance

\begin{tabular}{|l|r|r|r|r|r|r|r|r|r|r|r|r|}
\hline & \multicolumn{4}{|c|}{ Real GDP* } & \multicolumn{3}{|c|}{ Inflation* } & \multicolumn{3}{c|}{ Current account balance $^{\star *}$} \\
\cline { 2 - 13 } & 2005 & 2006 & $2007^{\mathrm{a}}$ & $2008^{\mathrm{a}}$ & 2005 & 2006 & $2007^{\mathrm{a}}$ & $2008^{\mathrm{a}}$ & 2005 & 2006 & $2007^{\mathrm{a}}$ & $2008^{\mathrm{a}}$ \\
\hline $\begin{array}{l}\text { Emerging } \\
\text { Asia }\end{array}$ & $\mathbf{8 . 7}$ & $\mathbf{9 . 3}$ & $\mathbf{9 . 2}$ & $\mathbf{8 . 3}$ & $\mathbf{3 . 5}$ & $\mathbf{3 . 7}$ & $\mathbf{4 . 9}$ & $\mathbf{4 . 2}$ & $\mathbf{4 . 5}$ & $\mathbf{5 . 8}$ & $\mathbf{6 . 6}$ & $\mathbf{6 . 5}$ \\
\hline China & 10.4 & 11.1 & 11.5 & 10.0 & 1.8 & 1.5 & 4.5 & 3.9 & 7.2 & 9.4 & 11.7 & 12.2 \\
\hline India & 9.0 & 9.7 & 8.9 & 8.4 & 4.2 & 6.1 & 6.2 & 4.4 & -1.0 & -1.1 & -2.1 & -2.6 \\
\hline Pakistan & 7.7 & 6.9 & 6.4 & 6.5 & 9.3 & 7.9 & 7.8 & 7.0 & -1.4 & -3.9 & -4.9 & -4.9 \\
\hline Bangladesh & 6.3 & 6.4 & 5.8 & 6.0 & 7.0 & 6.5 & 7.2 & 6.3 & - & 1.2 & 1.3 & 0.8 \\
\hline Indonesia & 5.7 & 5.5 & 6.2 & 6.1 & 10.5 & 13.1 & 6.3 & 6.2 & 0.1 & 2.7 & 1.6 & 1.2 \\
\hline Thailand & 4.5 & 5.0 & 4.0 & 4.5 & 4.5 & 4.6 & 2.0 & 2.0 & -4.5 & 1.6 & 3.7 & 2.2 \\
\hline Philippines & 4.9 & 5.4 & 6.3 & 5.8 & 7.6 & 6.2 & 3.0 & 4.0 & 2.0 & 4.3 & 3.8 & 2.6 \\
\hline Malaysia & 5.2 & 5.9 & 5.8 & 5.6 & 3.0 & 3.6 & 2.1 & 2.4 & 15.3 & 17.2 & 14.4 & 13.3 \\
\hline $\begin{array}{l}\text { South } \\
\text { Korea }\end{array}$ & 4.2 & 5.0 & 4.8 & 4.6 & 2.8 & 2.2 & 2.6 & 2.7 & 1.9 & 0.7 & 0.1 & -0.4 \\
\hline $\begin{array}{l}\text { Taiwan, } \\
\text { prov.China }\end{array}$ & 4.1 & 4.7 & 4.1 & 3.8 & 2.3 & 0.6 & 1.2 & 1.5 & 4.5 & 6.8 & 6.8 & 7.1 \\
\hline $\begin{array}{l}\text { Hong } \\
\text { Kong SAR }\end{array}$ & 7.5 & 6.9 & 5.7 & 4.7 & 0.9 & 2.0 & 2.0 & 3.2 & 11.4 & 10.8 & 11.2 & 9.5 \\
\hline Singapore & 6.6 & 7.9 & 7.5 & 5.8 & 0.5 & 1.0 & 1.7 & 1.7 & 24.5 & 27.5 & 27.0 & 25.4 \\
\hline
\end{tabular}

Source: IMF. World Economic Outlook, October 2007.

(a) Estimates

*Annual percent change

${ }^{\star *}$ Percentage of GDP

72. See David Burton and Alessandro Zanello: "Asia Ten Years After". Finance \& Development. June 2007, Volume 44, Number 2. International Monetary Fund. 
Table 15. Emerging Asia: OECD Country Risk Classification, November 2007

\begin{tabular}{|c|c|}
\hline COUNTRY & RISK CLASSIFICATION \\
\hline Afghanistan & 7 \\
\hline Cambodia & 7 \\
\hline North Korea & 7 \\
\hline Laos & 7 \\
\hline Myanmar & 7 \\
\hline Nepal & 7 \\
\hline Bangladesh & 6 \\
\hline Pakistan & 6 \\
\hline Indonesia & 5 \\
\hline Philippines & 5 \\
\hline Vietnam & 4 \\
\hline India & 3 \\
\hline Thailand & 3 \\
\hline Brunei & 2 \\
\hline China & 2 \\
\hline Malaysia & 2 \\
\hline Taiwan, province of China & 1 \\
\hline Hong Kong SAR & 1 \\
\hline South Korea & 0 \\
\hline Singapore & 0 \\
\hline
\end{tabular}

Source: OECD.

As Table 15 shows, countries of emerging Asia with the highest level of country risk are Afghanistan, Cambodia, North Korea, Laos, Myanmar and Nepal. Countries with a considerable level of risk are Bangladesh and Pakistan. Those with the lowest level of risk are South Korea and Singapore, followed by Taiwan and Hong Kong. Countries with very little country risk are Brunei, Malaysia and China. The OECD awards China (Group 2) less country risk than India (Group 3). The median score for all the countries of emerging Asia (21 countries) lies at some middle point between Groups 4 and 5.

7.2.3 AFRICA

Africa is experiencing an unprecedented period of economic growth. It grew by $5.6 \%$ in 2006 and rates of $5.7 \%$ and $6.5 \%$ are forecast for 2007 and 2008, respectively (see Table 16). Growth is due to various factors, such as improved macroeconomic stability, the positive impact of external debt cancellation under the HIPC initiative and other ad hoc initiatives, greater foreign capital flows into the region, increased oil production in some countries and 
strong demand for commodities. Meanwhile, Sub-Saharan Africa has been growing at an average rate of $4.5 \%$ since the year 2000 , representing the highest growth period since the early 1970s. This progress stems largely from the performance of oil-producing countries (notably Angola and Nigeria). Regional inflation rates are falling (with the exception of Zimbabwe), and fiscal and current account balances are recording a surplus at a regional level, the reason being the favourable performance of oil-exporting countries. Furthermore, countries such as Ghana and Tanzania are undertaking substantial structural reforms, which have allowed them to be included among the top 10 countries in terms of extent of their reforms, according to the World Bank's Doing Business publication ${ }^{73}$.

Despite the favourable economic stance in Africa, the region suffers from numerous structural weaknesses, such as a high poverty rate, precarious institutions, armed conflicts, political instability, corruption, inadequate infrastructures, and dependence on production and exports of a few goods, deepening the region's vulnerability to negative external events, such as bad weather or reduced demand for commodities. Furthermore, foreign direct investment is scarce despite China's recent interest in investing on the continent ${ }^{74}$. All of these factors explain that, except for a few countries, the continent's country risk is the highest in the world. The only African countries that enjoy investment grade from the three main rating agencies are South Africa and Tunisia. Countries with an investment grade from one or two agencies are Morocco, Botswana, Mauritius and Namibia.

Table 16. Africa: GDP, inflation and current account balance

\begin{tabular}{|c|c|c|c|c|c|c|c|c|c|c|c|c|}
\hline & \multicolumn{4}{|c|}{ Real GDP* } & \multicolumn{4}{|c|}{ Inflation* } & \multicolumn{4}{|c|}{ Current account balance** } \\
\hline & 2005 & 2006 & $2007^{a}$ & $2008^{a}$ & 2005 & 2006 & $2007^{a}$ & $2008^{a}$ & 2005 & 2006 & $2007^{a}$ & $2008^{a}$ \\
\hline Africa & 5.6 & 5.6 & 5.7 & 6.5 & 6.6 & 6.3 & 6.6 & 6.0 & 2.0 & 3.1 & - & 0.6 \\
\hline Maghreb & 4.1 & 5.2 & 4.3 & 5.6 & 1.5 & 3.1 & 3.6 & 3.4 & 11.7 & 14.6 & 10.4 & 9.7 \\
\hline Algeria & 5.1 & 3.6 & 4.8 & 5.2 & 1.6 & 2.5 & 4.5 & 4.3 & 20.7 & 25.6 & 19.4 & 18.4 \\
\hline Morocco & 2.4 & 8.0 & 2.5 & 5.9 & 1.0 & 3.3 & 2.5 & 2.0 & 2.4 & 3.4 & 0.7 & 0.2 \\
\hline Tunisia & 4.0 & 5.4 & 6.0 & 6.2 & 2.0 & 4.5 & 3.0 & 3.0 & -1.1 & -2.3 & -2.6 & -2.7 \\
\hline Sub-Saharan & 6.0 & 5.7 & 6.1 & 6.8 & 8.2 & 7.3 & 7.6 & 6.7 & -0.9 & -0.3 & -3.0 & -1.6 \\
\hline Angola & 20.6 & 18.6 & 23.1 & 27.2 & 23.0 & 13.3 & 11.9 & 8.9 & 16.8 & 23.3 & 7.6 & 10.7 \\
\hline Zimbabwe & -5.3 & -4.8 & -6.2 & -4.5 & 237.8 & $1,016.7$ & $16,170.2$ & $\ldots$ & -11.2 & -4.0 & -0.9 & ... \\
\hline Nigeria & 7.2 & 5.6 & 4.3 & 8.0 & 17.8 & 8.3 & 5.3 & 7.4 & 9.3 & 12.2 & 1.8 & 6.0 \\
\hline South Africa & 5.1 & 5.0 & 4.7 & 4.2 & 3.4 & 4.7 & 6.6 & 6.2 & -4.0 & -6.5 & -6.7 & -6.4 \\
\hline Oil Importers & 4.7 & 5.3 & 4.9 & 5.3 & 5.6 & 6.5 & 6.9 & 6.0 & -3.2 & -3.9 & -4.5 & -4.1 \\
\hline Oil Exporters & 7.5 & 6.3 & 7.5 & 9.1 & 8.9 & 5.9 & 6.1 & 6.0 & 11.5 & 14.7 & 7.2 & 8.9 \\
\hline
\end{tabular}

Source: IMF. World Economic Outlook, October 2007.
(a) Estimates
* Annual percent change
** Percentage of GDP

73. See "Doing Business 2007: How to reform". World Bank

74. See Silvia Iranzo and Isabel Herrero, "La estrategia económica de China en África". Boletín Económico de ICE n 2909, 16 - 30 April 2007. 
Table 17. Africa: OECD country risk classification, November 2007

\begin{tabular}{|c|c|}
\hline COUNTRY & RISK CLASSIFICATION \\
\hline Angola & 7 \\
\hline Cameroon & 7 \\
\hline Chad & 7 \\
\hline Equatorial Guinea & 7 \\
\hline Mozambique & 7 \\
\hline Central African Republic & 7 \\
\hline Democratic Republic of the Congo & 7 \\
\hline Sudan & 7 \\
\hline Mauritania & 7 \\
\hline Zimbabwe & 7 \\
\hline Gabon & 6 \\
\hline Ghana & 6 \\
\hline Kenya & 6 \\
\hline Libya & 6 \\
\hline Nigeria & 6 \\
\hline Senegal & 6 \\
\hline Tanzania & 6 \\
\hline Uganda & 6 \\
\hline Zambia & 6 \\
\hline Egypt & 4 \\
\hline Algeria & 3 \\
\hline Namibia & 3 \\
\hline Morocco & 3 \\
\hline South Africa & 3 \\
\hline Tunisia & 3 \\
\hline Botswana & 2 \\
\hline
\end{tabular}

Source: OECD.

Table 17 shows the country risk ratings of certain African countries, according to the OECD country risk classification. Countries with the maximum risk level include Angola, Equatorial Guinea, Sudan and Zimbabwe. Countries with a considerable risk are Nigeria, Gabon, Kenya, Senegal and Tanzania. Group 3 is made up of Algeria, Namibia, Morocco, South Africa and Tunisia. Group 2 only includes Botswana. The median score for all African countries (55 countries) is Group 7. 
It may be noted that a country's status as an oil exporter does not warrant a lower level of country risk. Morocco has a relatively low level of risk, despite not being an oil producer, whilst Angola, Equatorial Guinea and Nigeria, which produce plenty of oil, belong to the group with the highest risk. In Latin America, oil and gas exporting countries, such as Ecuador and Bolivia, have the maximum risk level whereas Chile, which is a net importer of gas and oil, belongs to a low-risk group ${ }^{75}$. In fact, an inverse relationship between economic development and ownership of oil resources is typically found in countries with a fragile institutional framework, a common feature of most African countries. Various explanations have been offered for this striking phenomenon ${ }^{76}$ :

$\Rightarrow \quad$ Oil exporters suffer from "Dutch disease" 77 , as appreciation of their currency associated with oil exports reduces the foreign competitiveness of the rest of their goods and services, preventing the development of non-oil sectors. One way to cure Dutch disease is to create Oil Stabilization Funds, which have the dual purpose of preventing currency appreciation and providing the country with income during periods of low oil prices. The snag is that governments of some of the countries where this type of fund exists (in Venezuela, for example) allow themselves to be tempted to spend income from the Fund even during periods of high oil prices.

$\Rightarrow \quad$ The oil sector produces little local added value, since the technology and equipment must usually be imported from developed countries. Furthermore, the sector is capital-intensive and employment opportunities are offered to medium to high skilled labour, generally found wanting in African countries. All this leads to a high concentration of revenue from oil exports landing in a few hands inside the producing country.

Revenue from oil sales is highly volatile, given oil price volatility. This makes it considerably harder to draw up the national budget. Moreover, the ups and downs in revenue provide an incentive for governments to amend the rules of the game, which undermines the rule of law and discourages foreign investments in the oil sector.

$\Rightarrow \quad$ Oil-producing countries derive substantial public income from oil exports. For this reason, governments can largely do without tax collection. This means that neither the governments nor the people who vote for them worry about managing oil revenue appropriately, leading to opaque behaviour when negotiating oil projects and spending the revenue. This revenue often ends up boosting bank accounts abroad held by senior civil servants and rulers, or funds civil wars, which increase country risk. The Extractive Industries Transparency Initiative (EITI), launched by Tony Blair in 2002, was meant to help to resolve the lack of transparency in oil contracts signed between governments and oil companies. This initiative has yet to produce results

75. See Silvia Iranzo and M. ${ }^{a}$ del Carmen Carrasco, "La situación energética en Latinoamérica". Boletín Económico de Banco de España. Febrero 2008.

76. See Jeffrey Sachs and Andrew M.Warner: "Natural resource abundance and economic growth". NBER Working Paper 5398; Paul Collier, "Natural Resources, Development and Conflict: Channels of Causation and Policy Interventions", World Bank, April 28, 2003; and Xavier Sala-i-Martin and Arvind Subramanian, 2003. "Addressing the Natural Resource Curse: An Illustration from Nigeria." IMF Working Paper 03/019. International Monetary Fund, Washington, D.C.

77. The expression dutch disease was coined in the 1970s as a result of the damage inflicted on Dutch flower exports by the appreciation of the guilder, caused by Dutch exports of natural gas. 
worthy of mention, although an increasing number of countries are signing $u^{78}$.

Finally, it is worth mentioning the "manna from heaven" syndrome, which affects countries where a significant volume of oil revenue is shared amongst the population, for whom this income becomes a way of life. Consequently, these countries have to import human and business capital from abroad in order to sustain economic development, deepening their inherent dependence on foreign markets.

7.2.4 CIS AND TURKEY

The CIS region (Commonwealth of Independent States) includes Armenia, Azerbaijan, Belarus, Estonia, Georgia, Kazakhstan, Kyrgyzstan, Moldova, Russia, Tajikistan, Turkmenistan, Ukraine and Uzbekistan. These countries are recording a considerable economic expansion, buoyed by the hydrocarbon industry, the strength of domestic demand and the high price of commodities. Current account balances have been boosted by energy exports, although imports are increasing at a considerable rate owing to the pressure of domestic demand, which has lead to a current account deficit in all of the countries of the region, except in Russia, Turkmenistan, Azerbaijan and Uzbekistan. The region's inflation is amongst the highest in the world, reaching two digits in several countries. At any rate, global indicators for the region are dominated by Russia (see Table 18).

The main medium-term risks in the CIS area stem from poor export and production diversification, which underscores these countries' vulnerability to international commodity price volatility. Foreign direct investment is generally low, given the poor investment climate, with numerous structural reforms pending, particularly in the energy sector, public administration, regulatory environment, tax system and development of the domestic financial markets. The only countries in the CIS area to enjoy investment grade from the three main rating agencies are Russia and Kazakhstan.

Turkey has enjoyed a significant improvement in its macroeconomic indicators since 2002, when it started to emerge from the 2001 sharp crisis, and embarked on implementing far-reaching reforms under the auspices of the IMF, with which it has signed various stand-by agreements -the credit arrangement currently in force was signed in May 2005 for a three year period-. Fiscal consolidation and inflation control in recent years are especially noteworthy. The present inflation rate is 9.6\%, down from 70\% during the period 1996-2001. Turkey has been growing at a sustained rate for several years, although the pace accelerated after the country was given approval by the EU in 2004 to become a candidate for entry into the Union ${ }^{79}$. Thereafter, foreign capital started to flow into the country, encouraged by the

78. In 2002, Tony Blair launched the Extractive Industries Transparency Initiative (EITI) during the Summit on Sustainable Development in Johannesburg, in order to address the lack of transparency in oil contracts signed between governments and oil companies. This organization's offices are located in Oslo and started to operate officially on 26 September 2007. Currently, the following 15 countries have been approved as candidates to become a part of this initiative: Azerbaijan, Cameroon, Gabon, Ghana, Guinea (Conakry), Kazakhstan, Kyrgystan, Liberia, Mali, Mauritania, Mongolia, Niger, Nigeria, Peru and Yemen. Nine other countries have been required to deliver more information before end-2007 in order to be considered candidates: Chad, Democratic Republic of Congo, Equatorial Guinea, Madagascar, Republic of Congo, Sao Tome and Principe, Sierra Leone, Trinidad and Tobago and East Timor. Eight donor countries have adhered to EITI: Australia, Belgium, France, Germany, Norway, United Kingdom, United States, Netherlands and Spain. Some 27 multinationals operating in the extractive industry have also become part of the initiative.

79. On 17 December 2004, the Council of the European Union agreed to open accession negotiations with Turkey as of 3 October 2005 
reduction in country risk brought about by expectation of membership. The most worrying aspects about the present situation in Turkey are the potential for political instability (conflicts between the AKP party and the secular), the still relatively high inflation rate, and the sizeable current account deficit (7.9\% of GDP) and external debt (50\% of GDP), which singles out the Turkish economy as a potential target for sudden investor panic reactions (the May-June 2006 crisis led to a depreciation of the Turkish lira of 20\% against the dollar and a 100 basis points increase in Turkish sovereign debt spreads).

Table 18. CIS and Turkey: GDP, inflation and current account balance

\begin{tabular}{|c|c|c|c|c|c|c|c|c|c|c|c|c|}
\hline & \multicolumn{4}{|c|}{ Real GDP* } & \multicolumn{4}{|c|}{ Inflation* } & \multicolumn{4}{|c|}{ Current account balance ${ }^{\star \star}$} \\
\hline & 2005 & 2006 & $2007^{a}$ & $2008^{a}$ & 2005 & 2006 & $2007^{a}$ & $2008^{a}$ & 2005 & 2006 & $2007^{a}$ & $2008^{a}$ \\
\hline CIS & 6.6 & 7.7 & 7.0 & 6.4 & 12.4 & 9.6 & 9.0 & 8.3 & 8.8 & 7.7 & 5.0 & 4.4 \\
\hline Russia & 6.4 & 6.7 & 7.0 & 6.5 & 12.7 & 9.7 & 8.1 & 7.5 & 11.1 & 9.7 & 5.9 & 3.3 \\
\hline Ukraine & 2.7 & 7.1 & 6.7 & 5.4 & 13.5 & 9.0 & 11.5 & 10.8 & 2.9 & -1.5 & -3.5 & -6.2 \\
\hline Kazakhstan & 9.7 & 10.7 & 8.7 & 7.8 & 7.6 & 8.6 & 8.6 & 7.8 & -1.8 & -2.2 & -2.2 & -1.1 \\
\hline Belarus & 9.3 & 9.9 & 7.8 & 6.4 & 10.3 & 7.0 & 8.1 & 10.0 & 1.6 & -4.1 & -7.9 & -8.1 \\
\hline Turkmenistan & 9.0 & 9.0 & 10.0 & 10.0 & 10.7 & 8.2 & 6.5 & 9.0 & 5.1 & 15.3 & 13.0 & 12.5 \\
\hline Armenia & 14.0 & 13.3 & 11.1 & 10.0 & 0.6 & 2.9 & 3.7 & 4.9 & -3.9 & -1.4 & -4.0 & -4.2 \\
\hline Azerbaijan & 24.3 & 31.0 & 29.3 & 23.2 & 9.7 & 8.4 & 16.6 & 17.0 & 1.3 & 15.7 & 31.4 & 39.9 \\
\hline Georgia & 9.6 & 9.4 & 11.0 & 9.0 & 8.3 & 9.2 & 8.5 & 8.1 & -9.8 & -13.8 & -15.7 & 15.2 \\
\hline Kyrgyzstan & -0.2 & 2.7 & 7.5 & 7.0 & 4.3 & 5.6 & 7.0 & 7.0 & 3.2 & -6.6 & -17.9 & 15.1 \\
\hline Moldova & 7.5 & 4.0 & 5.0 & 5.0 & 11.9 & 12.7 & 11.2 & 8.9 & -10.3 & -12.0 & -8.0 & -7.3 \\
\hline Tajikistan & 6.7 & 7.0 & 7.5 & 8.0 & 7.3 & 10.0 & 9.9 & 12.6 & -2.5 & -2.9 & -11.6 & -12.6 \\
\hline Uzbekistan & 7.0 & 7.3 & 8.8 & 7.5 & 10.0 & 14.2 & 12.2 & 9.8 & 13.6 & 18.8 & 21.1 & 21.0 \\
\hline Turkey & 7.4 & 6.1 & 5.0 & 5.3 & 8.2 & 9.6 & 8.2 & 4.6 & -6.2 & -7.9 & -7.5 & -7.0 \\
\hline
\end{tabular}

Source: IMF. World Economic Outlook, October 2007.
(a) Estimates
* Annual percent change
** Percentage of GDP

Table 19 shows the levels of country risk for CIS and Turkey according to the OECD classification. Countries with the highest level of risk are Belarus, Turkmenistan, Kyrgyzstan, Moldova, Tajikistan and Uzbekistan. Countries with a very high level of risk are Armenia and Georgia. The country with the lowest level of country risk is Russia. The median score for countries in the CIS region and Turkey (13 countries) is Group 6. 
Table 19. CIS and Turkey: OECD country risk classification. November 2007

\begin{tabular}{|l|c|}
\hline COUNTRY & RISK CLASSIFICATION \\
\hline Uzbekistan & 7 \\
\hline Tajikistan & 7 \\
\hline Moldova & 7 \\
\hline Kyrgyzstan & 7 \\
\hline Turkmenistan & 7 \\
\hline Belarus & 7 \\
\hline Armenia & 6 \\
\hline Georgia & 6 \\
\hline Ukraine & 5 \\
\hline Azerbaijan & 5 \\
\hline Turkey & 5 \\
\hline Kazakhstan & 4 \\
\hline Russia & 3 \\
\hline
\end{tabular}

Source: OECD.

7.2.5 MIDDLE EAST

Oil-exporting countries in the Middle East are enjoying an economic bonanza, as a result of oil price and oil export volume increase ${ }^{80}$. Non-oil exporting countries in the region are also recording high growth rates, supported by foreign direct investments and a favourable international environment. The region's overall growth rate reached 5.6\% in 2006 (see Table 20) and foreign reserves exceeded $\$ 540$ billion in 2006. Inflation rates are generally contained at acceptable levels (except for Iran) and the countries are better prepared than they were in the aftermath of the second oil shock to face possible drops in oil prices.

Risks in this region may be summed up by lack of product diversification, which renders the region vulnerable to international price movements of a reduced number of goods, low occupation rate of its locals, and the countries' special geographical situation and cultural environment, which heightens their vulnerability to religious and armed conflicts in the region. Also, some of the countries' exchange rate peg to the dollar may pose monetary problems of its own given the present stance of oil price bonanza. Of the countries that make up the region, investment grades have been awarded to Israel, Saudi Arabia, Kuwait, Bahrain, Qatar, Oman (Fitch does not rate the latter two countries) and the United Arab Emirates (only rated by Moody's).

Some of the factors mentioned in the paragraphs devoted to Africa as possible causes of delay in economic development in oil-producing countries also apply to the Middle East region.

80. On 17 December 2004, the Council of the European Union agreed to open accession negotiations with Turkey as of 3 October 2005. 
Table 20. Middle East: GDP, inflation and current account balance

\begin{tabular}{|c|r|r|r|r|r|r|r|r|r|r|r|r|}
\hline & \multicolumn{4}{|c|}{ Real GDP* } & \multicolumn{4}{|c|}{ Inflation* } & \multicolumn{3}{c|}{ Current account balance ${ }^{\star}$} \\
\cline { 2 - 15 } & 2005 & 2006 & $2007^{\mathrm{a}}$ & $2008^{\mathrm{a}}$ & 2005 & 2006 & $2007^{\mathrm{a}}$ & $2008^{\mathrm{a}}$ & 2005 & 2006 & $2007^{\mathrm{a}}$ & $2008^{\mathrm{a}}$ \\
\hline Middle East & $\mathbf{5 . 4}$ & $\mathbf{5 . 6}$ & $\mathbf{5 . 9}$ & $\mathbf{5 . 9}$ & $\mathbf{6 . 9}$ & $\mathbf{7 . 5}$ & $\mathbf{1 0 . 8}$ & $\mathbf{9 . 2}$ & $\mathbf{1 9 . 4}$ & $\mathbf{1 9 . 7}$ & $\mathbf{1 6 . 7}$ & $\mathbf{1 6 . 0}$ \\
\hline Oil-exporters & $\mathbf{5 . 6}$ & $\mathbf{5 . 4}$ & $\mathbf{5 . 7}$ & $\mathbf{5 . 6}$ & $\mathbf{6 . 7}$ & $\mathbf{8 . 4}$ & $\mathbf{1 1 . 0}$ & $\mathbf{9 . 7}$ & $\mathbf{2 2 . 3}$ & $\mathbf{2 2 . 7}$ & $\mathbf{1 9 . 2}$ & $\mathbf{1 8 . 5}$ \\
\hline Iran & 4.4 & 4.9 & 6.0 & 6.0 & 12.1 & 13.6 & 19.0 & 17.7 & 8.8 & 8.7 & 7.6 & 6.6 \\
\hline Saudi Arabia & 6.1 & 4.3 & 4.1 & 4.3 & 0.7 & 2.2 & 3.0 & 3.0 & 28.5 & 27.4 & 22.2 & 20.1 \\
\hline Kuwait & 10.0 & 5.0 & 3.5 & 4.8 & 4.1 & 2.8 & 2.6 & 2.6 & 40.5 & 43.0 & 37.8 & 35.3 \\
\hline Mashreq & $\mathbf{4 . 2}$ & $\mathbf{6 . 1}$ & $\mathbf{6 . 3}$ & $\mathbf{6 . 5}$ & $\mathbf{7 . 7}$ & $\mathbf{5 . 3}$ & $\mathbf{9 . 6}$ & $\mathbf{7 . 2}$ & $\mathbf{- 2 . 3}$ & $\mathbf{- 2 . 6}$ & $\mathbf{- 2 . 4}$ & $\mathbf{- 2 . 5}$ \\
\hline Egypt & 4.5 & 6.8 & 7.1 & 7.3 & 8.8 & 4.2 & 10.9 & 7.8 & 3.2 & 0.8 & 1.4 & 0.8 \\
\hline Syria & 3.3 & 4.4 & 3.9 & 3.7 & 7.2 & 10.0 & 7.0 & 7.0 & -4.1 & -6.2 & -5.6 & -6.6 \\
\hline Jordan & 7.1 & 6.3 & 6.0 & 6.0 & 3.5 & 6.3 & 5.0 & 4.5 & -17.9 & -14.0 & -12.6 & -11.9 \\
\hline Lebano & 1.0 & - & 2.0 & 3.5 & -0.7 & 5.6 & 3.5 & 2.5 & -13.6 & -6.2 & -10.6 & -9.4 \\
\hline Israel & 5.3 & 5.2 & 5.1 & 3.8 & 1.3 & 2.1 & 0.5 & 2.5 & 3.3 & 5.6 & 3.7 & 3.2 \\
\hline
\end{tabular}

Source: IMF. World Economic Outlook, October 2007.
(a) Estimates
* Annual percent change
** Percentage of GDP

Table 21 presents country risk ratings for the Middle East region, according to the OECD classification. Countries with the highest levels of risk are Syria, Lebanon and Iraq. Other countries with a substantial degree of risk are Iran and Yemen. Countries with the lowest levels of country risk are Saudi Arabia, Kuwait, Oman, Bahrain, Qatar and the United Arab Emirates, all of them exporters of oil and/or gas. The median score for the countries of the region (14 countries) lies somewhere between Groups 3 and 4.

Table 21. Middle East: OECD country risk classification, November 2007

\begin{tabular}{|l|c|}
\hline COUNTRY & RISK CLASSIFICATION \\
\hline Syria & 7 \\
\hline Lebanon & 7 \\
\hline Iraq & 7 \\
\hline Iran & 6 \\
\hline Yemen & 6 \\
\hline Jordan & 5 \\
\hline Egypt & 4 \\
\hline Israel & 3 \\
\hline Saudi Arabia & 2 \\
\hline Kuwait & 2 \\
\hline Oman & 2 \\
\hline Bahrain & 2 \\
\hline Qatar & 2 \\
\hline United Arab Emirates & 2 \\
\hline
\end{tabular}

Source: ECD. 
Developed countries ("advanced economies" in IMF terminology), comprise the United States, the European Union, Japan, Canada, Australia, New Zealand, Switzerland, Norway, Iceland, Israel, South Korea, Taiwan (province of China), Hong Kong SAR and Singapore ${ }^{81}$.

Table 22 offers data on GDP growth, prices and unemployment rates for some of these countries.

Table 22. Developed countries: GDP, inflation and unemployment

\begin{tabular}{|c|c|c|c|c|c|c|c|c|c|c|c|c|}
\hline & \multicolumn{4}{|c|}{ Real GDP* } & \multicolumn{4}{|c|}{ Inflation* } & \multicolumn{4}{|c|}{ Unemployment rate ${ }^{\star *}$} \\
\hline & 2005 & 2006 & $2007^{a}$ & $2008^{a}$ & 2005 & 2006 & $2007^{a}$ & $2008^{a}$ & 2005 & 2006 & $2007^{a}$ & $2008^{2}$ \\
\hline $\begin{array}{l}\text { Developed } \\
\text { countries }\end{array}$ & 2.5 & 2.9 & 2.5 & 2.2 & 2.3 & 2.3 & 2.1 & 2.0 & 6.0 & 5.6 & 5.3 & 5.5 \\
\hline United States & 3.1 & 2.9 & 1.9 & 1.9 & 3.4 & 3.2 & 2.7 & 2.3 & 5.1 & 4.6 & 4.7 & 5.7 \\
\hline Japan & 1.9 & 2.2 & 2.0 & 1.7 & -0.3 & 0.3 & - & 0.5 & 4.4 & 4.1 & 4.0 & 4.0 \\
\hline United Kingdom & 1.8 & 2.8 & 3.1 & 2.3 & 2.0 & 2.3 & 2.4 & 2.0 & 4.8 & 5.4 & 5.4 & 5.4 \\
\hline Canada & 3.1 & 2.8 & 2.5 & 2.3 & 2.2 & 2.0 & 2.2 & 1.9 & 6.8 & 6.3 & 6.1 & 6.2 \\
\hline Australia & 2.8 & 2.7 & 4.4 & 3.8 & 2.7 & 3.5 & 2.3 & 2.8 & 5.1 & 4.8 & 4.4 & 4.3 \\
\hline Euro Zone & 1.5 & 2.8 & 2.5 & 2.1 & 2.2 & 2.2 & 2.0 & 2.0 & 8.6 & 7.8 & 6.9 & 6.8 \\
\hline Germany & 0.8 & 2.9 & 2.4 & 2.0 & 1.9 & 1.8 & 2.1 & 1.8 & 9.1 & 8.1 & 6.5 & 6.3 \\
\hline France & 1.7 & 2.0 & 1.9 & 2.0 & 1.9 & 1.9 & 1.6 & 1.8 & 9.7 & 9.5 & 8.6 & 8.0 \\
\hline Italy & 0.1 & 1.9 & 1.7 & 1.3 & 2.2 & 2.2 & 1.9 & 1.9 & 7.7 & 6.8 & 6.5 & 6.5 \\
\hline Spain & 3.6 & 3.9 & 3.7 & 2.7 & 3.4 & 3.6 & 2.5 & 2.8 & 9.2 & 8.5 & 8.1 & 8.2 \\
\hline
\end{tabular}

Source: IMF. World Economic Outlook, October 2007.

(a) Estimates

* Annual percent change

** Percentage of labour force

Developed countries have low or even negligible levels of country risk, the external debt default probability being practically equal to nought. These countries generally enjoy well-established democracies, institutional strength and political stability, and have a faultless debt payment record and culture. Furthermore, some of them issue currencies which are accepted internationally as a means of payment, or belong to a monetary union whose currency is equally internationally accepted as a means of payment, thereby resulting in the absence of transfer risk.

In the case of certain European Union countries that do not belong to the euro zone, such as Poland, Hungary, Czech Republic, Slovakia, Slovenia, Estonia, Latvia, Lithuania, Cyprus, Malta, Bulgaria and Romania, country risk is low, among other reasons because EU institutions have established assistance mechanisms in the event of balance of payment

81. Israel, South Korea, Taiwan (province of China), Hong Kong SAR and Singapore have also been included in their respective regions for the purposes of country risk analysis, in order to draw a more complete picture of the countries. 
difficulties $^{82}$, which, on account of their sole existence, grant a high level of confidence to investors, keeping these countries relatively safe from speculative attacks against their currencies. Furthermore, in the event that the use of these mechanisms should prove inadequate to solve eventual payment crises, European Union institutions would most likely adopt measures as deemed necessary to prevent a member country from defaulting on its debt, as this could ultimately harm ratings and spreads of other member countries and EU institutions.

All developed countries have investment grades from the three main rating agencies. OECD country risk ratings for developed countries vary between Groups 0, 1, 2 and 3 (see Table 23). Group 3 includes Hungary, Israel, Latvia, Bulgaria and Romania. Group 2 features Poland, Estonia, Lithuania, Cyprus and Malta. Group 1 includes Taiwan, the Czech Republic, Slovakia and Hong Kong. Finally, Group 0 includes the most advanced countries, such as the United States, Japan, Canada, Australia, New Zealand, Euro Area countries, Sweden, Denmark, the United Kingdom, Norway, Switzerland, Iceland, Singapore and South Korea. The median OECD country risk rating for developed countries is 0 .

Table 23. Selected developed countries: OECD county risk classification, November 2007

\begin{tabular}{|l|c|}
\hline COUNTRY & RISK CLASSIFICATION \\
\hline United States & 0 \\
\hline Japan & 0 \\
\hline Canada & 0 \\
\hline Australia & 0 \\
\hline New Zealand & 0 \\
\hline Euro zone countries & 0 \\
\hline Sweden & 0 \\
\hline Denmark & 0 \\
\hline United Kingdom & 0 \\
\hline Norway & 0 \\
\hline Switzerland & 0 \\
\hline Iceland & 0 \\
\hline South Korea & 0 \\
\hline Singapore & 0 \\
\hline Hong Kong SAR & 1 \\
\hline Taiwan (province of China) & 1 \\
\hline Czech Republic & 1 \\
\hline Slovak Republic & 1 \\
\hline
\end{tabular}

Source: OECD

82. EU Council Regulation (EC) $n^{\circ} 332 / 2002$, of 18 February 2002, establishes a medium-term financial assistance mechanism for Member States balances of payments, that provides for granting of medium-term loans to Member States that have not adopted the euro and are experiencing current or capital account balance of payments difficulties. This Regulation was enacted following the Maastricht Treaty (7 February 1992) establishment of mandadory freedom of capital movements between euro and non-euro Member States. This mechanism carries the following features: 1) the maximum principal loan amount is $€ 12$ billion; 2) the Council, on the Commission's request, decides, by a qualified majority, on this mechanism's application to a Member State and its conditions (amount, term, economic policy conditions attached to the assisstance and type of loan). 
Table 24 presents a summary of the median country risk ratings for each region as well as for all the countries in the world rated by the OECD (172 countries). Regions that improve the worldwide median of Group 6 are developed countries, Middle East, Emerging Asia, and Latin America. CIS countries and Turkey are classified on the world median. Africa is the only region with a level of country risk that exceeds the median.

Table 24. OECD regional country risk median scores. November 2007

\begin{tabular}{|l|c|}
\hline REGION & MEDIAN SCORE \\
\hline Latin America & 5 \\
\hline Emerging Asia & $4-5$ \\
\hline Africa & 7 \\
\hline CIS + Turkey & 6 \\
\hline Middle East & $3-4$ \\
\hline Developed countries & 0 \\
\hline World (172 rated countries) & $\mathbf{6}$ \\
\hline
\end{tabular}

Source: OECD and author's own calculations. 


\subsection{In Spain}

As has already been mentioned, supervisory actions in the field of country risk started in western countries after the Latin American debt crisis in the early 1980s. In Spain, the central bank (Bank of Spain) considered putting into place regulations on country risk in 1982, which was reflected in the setting up of the Country Risk Service, for the purposes of advising the banking supervision on this subject and helping to administer the new regulations. Two years later, in 1984, the first Bank of Spain Circular on country risk was enacted.

Country risk of Spanish credit institutions is currently regulated by Annexe IX of Circular 4/2004, of 22 December, to credit institutions, about rules on public and confidential financial information and models of financial statements (BOE ${ }^{83}, 30$ December 2004). This regulation, which was passed in order to adapt the accounting system of Spanish credit institutions to the new accounting framework deriving from adoption by the EU of International Financial Reporting Standards (IFRS), includes the accounting rules concerning analysis and cover of credit risk, one of its components being country risk. A substantive element of the country risk guidelines is regulation of risk cover, for which the Circular offers a set of criteria.

\subsubsection{RISK DEFINITION AND CLASSIFICATION}

According to Spanish regulations, country risk is defined as "the risk associated to customers residing in a specific country due to circumstances other than standard commercial risk. Country risk comprises sovereign risk, transfer risk and other risks derived from international financial activity, defined as follows:

a) Sovereign risk is that of state creditors or institutions guaranteed by them, where legal actions against the borrower or ultimate agent responsible for the payments may be ineffective for sovereignty reasons.

b) Transfer risk is that of foreign creditors of residents of a country experiencing a general inability to pay its debts, due to lack of the debt denomination currencies.

c) Other risks derived from international financial activity are those resulting from one of the following situations: civil or international war, revolution, similar events or catastrophes; especially serious political or economic events, such as balance of payment crises or significant changes in monetary parity which can cause general insolvency; expropriation, nationalization o or embargo dictated by foreign authorities, and express or tacit measures adopted by a foreign government or by the Spanish authorities which give rise to non-compliance of contracts."

Country risk regulations are based on the following principles:

- $\quad$ Debt instrument portfolios, contingent risks and contingent commitments must be analyzed in order to assess credit risk, with separate analyses of insolvency risks attributable to the customer or to country risk.

83. BOE stands for "Boletín Oficial del Estado", which is the official journal that publishes all regulations enacted in Spain. 
- Operations are to be classified in the category associated to the risk that is attributable to the client, unless a worse category should be assigned to country risk.

- The credit institutions themselves will carry out an overall assessment of country risk, for the purposes of classifying all countries into six risk groups, numbered from 1 to 6 , group 1 being that of least risk and group 6 that of the highest risk.

- The policies, methods and procedures handled by credit institutions when assuming and covering risk must be approved by the board and be adequately justified and documented.

The indicators that the credit institutions must take into consideration when classifying countries in the six risk groups are:

a) Payment record, with special emphasis, where appropriate, on fulfilment of restructuring agreements and payments due to international financial institutions.

b) External financial situation, with particular attention to indicators of total external debt, short-term external debt, ratios of debt service to Gross Domestic Product and to exports, and foreign reserves.

c) Economic situation, based essentially on:

(i) Indicators reflecting budgetary aggregates, monetary aggregates and balance of payments aggregates.

(ii) Indicators reflecting economic growth (income level, savings or investment rate, GDP growth, etc.) and vulnerability (export diversification, aid dependence, etc.).

d) Market indicators, with special attention to credit ratings carried out by prestigious rating agencies, debt quotations on secondary markets, market access and debt interest rate differentials.

Depending on the aforementioned indicators, operations are to be classified in the six risk groups, taking into account the following classification criteria:

$\Rightarrow \quad$ Group 1. This group includes operations with ultimate borrowers resident in European Union countries, Norway, Switzerland, Iceland, the United States, Canada, Japan, Australia and New Zealand.

$\Rightarrow \quad$ Group 2. This group includes operations with ultimate borrowers resident in countries other than those in Group 1 that bear a low risk.

$\Rightarrow \quad$ Group 3. This group includes operations with ultimate borrowers resident in countries with a significant macroeconomic deterioration which may affect the country's ability to pay. This deterioration may be manifested through: significant and persistent deficits in the balance of payments current account, high proportions 
of short-term debt relative to total external debt or net foreign reserves, a strong depreciation of the exchange rate or significant changes in the exchange rate system (such as abandonment, or the imminent risk of abandoning, monetary arrangements such as currency boards or managed exchange rate floating systems), dramatic falls in stock market prices, and external debt ratios and debt service ratios well above those of countries classified in groups 1 and 2 or of surrounding countries.

$\Rightarrow \quad$ Group 4. This group includes operations with ultimate borrowers resident in countries with a profound macroeconomic deterioration which may seriously affect the country's ability to pay. This group includes operations in countries classified in group 3 which experience a deterioration of the indicators mentioned in the previous section.

$\Rightarrow \quad$ Group 5. This group includes operations with ultimate borrowers resident in countries experiencing protracted difficulties in paying the debt service, the chances of repayment being uncertain.

$\Rightarrow \quad$ Group 6. This category includes operations where the chances of repayment are considered to be remote because of circumstances attributable to the country. In any case, this group includes operations with ultimate borrowers resident in countries that have repudiated their debts or have not paid any principal or interest for four years.

$\Rightarrow \quad$ Operations with multilateral organizations whose membership is made up of countries classified in groups 3,4 and 5 are to be classified in the group featuring the largest number of member countries, except for the International Bank for Reconstruction and Development (World Bank), the International Finance Corporation, the Inter-American Development Bank, The Asian Development Bank, the African Development Bank, the Council of Europe Development Bank, the Nordic Investment Bank, the Caribbean Development Bank, and the European Bank for Reconstruction and Development, which will be classified in group 1. If there were objective reasons for a better rating, a reasoned request should be submitted to Bank of Spain proposing that which is considered most appropriate.

8.1.2 COUNTRY RISK COVER

Debt instruments and contingent risks classified for the purposes of country risk in groups 3 to 6 must be covered with the following minimum provision or reserve percentages:
a) Group 3
b) Group 4
c) Group 5 .
d) Group 6 $100.0 \%$

These percentages are applied to the total outstanding amount of the debt instruments and contingent risks. 
Risks excluded from country risk cover include:

Risks in countries belonging to Groups 1 or 2.

Risks covered by CESCE and other insurance companies, provided the insured risks cover all of the risks included in the definition of country risk.

Commercial credits, and financial credits derived from them, with maturities no higher than a year from the date of use of the initial credit.

Private sector operations in countries belonging to the monetary zone of a currency issued by a country classified in group 1.

Reserves or provisions set aside each financial year are tax-deductible up to the minimum amount established by the Circular 4/2004. Credit institutions are free to set aside reserves that exceed the stated percentages, but the excess on the legal minimum will not be tax-deductible.

\subsection{In the European Union and the United States}

There is no common regulation on country risk either at European Union level or at the euro zone level. Different country risk supervision methods coexist amongst the various supervisory agencies and authorities, as regards the very existence of country risk supervision, the carrying out of studies on country risk, the confidentiality of results, the type of agency involved in the analysis, the number of countries analyzed and the frequency of the analyses.

In the United States, various state and federal agencies responsible for financial supervision ${ }^{84}$ coordinate their country risk studies and assessments through the Interagency Country Exposure Review Committee (ICERC), where the abovementioned agencies are represented. This committee meets at least once a year, and assigns and updates country risk ratings of countries where the US banks concentrate their international risks. The mandatory risk cover system, hinging on country risk ratings, is similar to that in force in Spain.

84. In the United States, the following institutions are responsible for financial supervision:

- $\quad$ Office of the Comptroller of the Currency (OCC). The OCC supervises National Banks, which obtain their licence to operate from the federal government.

- $\quad$ Local State Banking Commissions. They supervise the state-chartered banks (known as state banks), which have a licence to operate in a specific state of the United States.

- $\quad$ Federal Deposit Insurance Corporation (FDIC). The FDIC supervises commercial banks that have a deposit insurance agreement with FDIC.

- $\quad$ Federal Reserve District Banks. These banks supervise the Banking Holding Companies (BHC), which are companies with shares in National Banks or other financial entities within and outside the United States.

- $\quad$ Federal Reserve Board of Governors (FRBG). The FRBG oversees supervision by federal and state agencies in order to identify systemic problems.

- $\quad$ Office of Thrift Supervision (OTS). The OTS supervises savings banks. 


\section{Conclusions: country risk past and future}

This section will carry out a retrospective analysis of the level of country risk in the past years, and will outline the risks that lie ahead in this area.

In order to assess whether country risk has in fact increased or decreased in recent years, an analysis may be carried out to analyze whether the countries have economic and political systems which as a whole have helped to improve the global country risk situation. Also, a systematic study may be made of the evolution of specific country risk indicators, such as OECD country risk ratings or sovereign ratings issued by rating agencies.

After close observation of the recent economic and political evolution of countries, it may be concluded that worldwide country risk has dropped, whilst recognising that many challenges lie ahead of many countries in their path towards reducing their country risk. World economic developments have generally been favourable, except for occasional payment crises that have for the most part been happily resolved. Emerging and developing countries have grown on average at a 5.3\% annual rate during the 2000-2005 period. The IMF has forecast growth rates of $8.1 \%$ and $7.4 \%$ for 2007 and 2008 respectively for these countries. World poverty has dropped, particularly in emerging Asia. In 1990, 27.9\% of world population lived on less than $\$ 1$ per day. By 2002 that percentage had dropped to $21.1 \%$. By 2015, it is forecast to drop to $10.2 \%{ }^{85}$. As for politics, there has been a worldwide progression towards democracy, albeit with many ups and downs and extremely serious political events. In the year 2000 the world population living in a country with a democratic political system accounted for $58 \%$ of the world population, up from $31 \%$ in $1950^{86}$.

The OECD data allow tracking the recent evolution of country risk by observing country-risk ratings for the period 1999-2007 (data prior to 1999 are not available). The figures show that the number of upgrades in country risk ratings more than doubled the number of downgrades ${ }^{87}$ during the reference period, which amounts to a substantial improvement in country risk worldwide during that period. Table 25 provides data by region on country risk rating upgrades and downgrades, which may be summarized as follows:

- $\quad$ For the emerging and developing world as a whole, the number of upgrades roughly doubled the number of downgrades. Overall, there were 93 upgrades as against 41 downgrades.

- $\quad$ The region with the highest proportion of upgrades was Eastern Europe, CIS and Turkey (37 upgrades as against only 4 downgrades). This evolution was closely related to the necessary adaptation of many Eastern European countries' political and economic systems prior to entering the European Union and the fact of entry itself, which involved an automatic improvement in their rating.

85. See Global Economic Prospects 2006: Economic Implications of Remittances and Migration. World Bank.

86. See the annual publication Freedom in the World.

87. When drawing up Table 25, ratings for tiny islands and territories have not been taken into account, as they have little weight in the world economy. 
- $\quad$ The Middle East region also had a highly favourable relationship between upgrades (11) and downgrades (5). Improvement of external accounts pushed by increases in oil and gas prices since 2003 played a significant role.

- Latin America and the Caribbean also recorded a considerable country risk improvement, both in small countries and in most large ones. Upgrades (20) significantly outpaced downgrades (13).

Africa also witnessed a reduction in its country risk, particularly in the area of the Maghreb. The number of upgrades (18) was 50\% greater than the number of downgrades (12).

Emerging Asia was the region with the poorest behaviour as reflected in the relationship between upgrades and downgrades (7 upgrades versus 7 downgrades). The downgrades mainly occurred during the early years of the reference period, when the adverse effects of the Asian crisis could still be felt.

Table 25. Evolution of OECD country risk classifications, 1999-2007

\begin{tabular}{|l|c|c|}
\hline & NUMBER OF UPGRADES & NUMBER OF DOWNGRADES \\
\hline $\begin{array}{l}\text { Emerging-Developing } \\
\text { Countries }\end{array}$ & $\mathbf{9 3}$ & $\mathbf{4 1}$ \\
\hline Latin America & 20 & 13 \\
\hline Emerging Asia & 7 & 7 \\
\hline Africa & 18 & 12 \\
\hline $\begin{array}{l}\text { Eastern Europe, } \\
\text { CIS + Turkey }\end{array}$ & 37 & 4 \\
\hline Middle East & 11 & 5 \\
\hline
\end{tabular}

Source: OECD and author's own calculations.

Rating agencies also offer data which enable the assessment of country risk progression, in terms of sovereign risk, by observing foreign currency sovereign ratings of the different countries. Table 26 shows the number of rating upgrades and downgrades during the period January 1995-November 2007. Upgrades more than doubled downgrades during this period, and in each of the thirteen years studied, upgrades outpaced downgrades, with the exception of the years 1997, 1998 and 2001, which saw the 1997-1998 Asian crisis and the 2001 Argentine crisis (in 2001 Argentina suffered 17 downgrades). Altogether, it may be concluded that sovereign risk, one of the key components of country risk, has fallen in the last thirteen years. 
Table 26. Moody's, Standard \& Poor's and Fitch sovereign ratings, 1995-2007

\begin{tabular}{|l|c|c|}
\hline Year & NUMBER OF UPGRADES & NUMBER OF DOWNGRADES \\
\hline $1995^{*}$ & 9 & 4 \\
\hline $1996^{*}$ & 9 & 3 \\
\hline $1997^{*}$ & 11 & 12 \\
\hline $1998^{*}$ & 12 & 36 \\
\hline $1999^{*}$ & 22 & 16 \\
\hline $2000^{*}$ & 24 & 6 \\
\hline 2001 & 38 & 41 \\
\hline 2002 & 59 & 30 \\
\hline 2003 & 63 & 29 \\
\hline 2004 & 50 & 10 \\
\hline 2005 & 55 & 16 \\
\hline 2006 & 54 & 10 \\
\hline 2007 (Jan.-Nov.) & 68 & 10 \\
\hline TOTAL & $\mathbf{4 7 4}$ & $\mathbf{2 2 3}$ \\
\hline
\end{tabular}

Source: Moody's, Standard \& Poor's, FitchRatings and author's own calculations.

*Does not include data from Moody's.

As for the future of country risk, it is extremely difficult to make long-term forecasts in this field, given the number of very different variables that must be considered. Four types of risk that could end the current benign country risk cycle may be identified.

The first type of risk is a general economic risk that owes to the possibility that a large country (United States is currently the most likely candidate) could suffer a substantial recession, with adverse effects on the rest of the world for a long period of time. The second is the risk of break-out of a large-scale military conflict, in the Middle East, for example. The third is the risk that global warming, as a long-term tendency, could have a net damaging effect on the world economy, if mechanisms to contain emissions, such as Kyoto, failed, and large countries (for example, United States or China) did not in turn control their emissions ${ }^{88}$ Finally, the development of economic protectionism by advanced countries against the commercial threat of the largest emerging countries would substantially impact adversely international trade flows and hamper sustained growth in developing countries.

None of the above risks is easy to quantify presently, and most are unlikely to materialise in the near future. As such, it may be stated that worldwide prospects for country risk are generally favourable in the short and medium-term. In the longer term forecasts in this

88. Global warming would most likely result in an increase in worldwide demand for energy, because a reduction in energy demand due to lower heating needs would be more than offset by an increase in energy demand for air conditioning (the United States consumes roughly 1.5 times more energy in air conditioning than in heating). The greater energy demand would benefit the oil and gas-producing countries, but would have adverse effects on the rest. Furthermore, global warming would generate an increase in public spending, due to financial reconstruction efforts of areas affected by greater meteorological volatility (storms, hurricanes, typhoons, flooding). Countries with a large tourism sector relying on sun and beach would be particularly damaged by a possible rise in the sea level. The overall net effect of all of these factors would probably be an increase of country risk. 
field are doomed to failure, given the huge number of qualitative and quantitative variables that play a part in long-term risk assessments. The improvement in knowledge and in the analytical tools used to assess risks in each country and region will remain a challenge for country risk analysts. 
ANNEXE 1: OECD Country Risk Classification

\begin{tabular}{|c|c|}
\hline \multicolumn{2}{|c|}{ OECD Country Risk Classification, 30 November 2007} \\
\hline COUNTRIES & CLASSIFICATION \\
\hline Afghanistan & 7 \\
\hline Albania & 6 \\
\hline Algeria & 3 \\
\hline Angola & 7 \\
\hline Antigua and Barbuda & 6 \\
\hline Argentina & 7 \\
\hline Armenia & 6 \\
\hline Aruba & 4 \\
\hline Australia & 0 \\
\hline Austria & 0 \\
\hline Azerbaijan & 5 \\
\hline Bahamas & 3 \\
\hline Bahrain & 2 \\
\hline Bangladesh & 6 \\
\hline Belarus & 7 \\
\hline Belgium & 0 \\
\hline Belize & 7 \\
\hline Benin & 6 \\
\hline Bolivia & 7 \\
\hline Bosnia-Herzegovina & 7 \\
\hline Botswana & 2 \\
\hline Brazil & 3 \\
\hline Brunei & 2 \\
\hline Bulgaria & 3 \\
\hline Burkina Faso & 7 \\
\hline Burma & 7 \\
\hline Burundi & 7 \\
\hline Cambodia & 7 \\
\hline Cameroon & 7 \\
\hline Canada & 0 \\
\hline Cape Verde & 6 \\
\hline Central African Republic & 7 \\
\hline Chad & 7 \\
\hline Chile & 2 \\
\hline China & 2 \\
\hline Colombia & 4 \\
\hline
\end{tabular}




\begin{tabular}{|c|c|}
\hline Congo, Democratic Republic (former Zaire) & 7 \\
\hline Congo-Brazzaville & 7 \\
\hline Costa Rica & 3 \\
\hline Croatia & 4 \\
\hline Cuba & 7 \\
\hline Cyprus & 2 \\
\hline Czech Republic & 1 \\
\hline Denmark & 0 \\
\hline Dominican Republic & 5 \\
\hline Ecuador & 7 \\
\hline Egypt & 4 \\
\hline El Salvador & 4 \\
\hline Equatorial Guinea & 7 \\
\hline Eritrea & 7 \\
\hline Estonia & 2 \\
\hline Ethiopia & 7 \\
\hline Finland & 0 \\
\hline France & 0 \\
\hline Gabon & 6 \\
\hline Gambia & 7 \\
\hline Georgia & 6 \\
\hline Germany & 0 \\
\hline Ghana & 6 \\
\hline Greece & 0 \\
\hline Guatemala & 5 \\
\hline Guinea-Bissau & 7 \\
\hline Guinea-Conakry & 7 \\
\hline Guyana & 7 \\
\hline Haiti & 7 \\
\hline Honduras & 6 \\
\hline Hong Kong & 1 \\
\hline Hungary & 3 \\
\hline Iceland & 0 \\
\hline India & 3 \\
\hline Indonesia & 5 \\
\hline Iran & 6 \\
\hline Iraq & 7 \\
\hline Ireland & 0 \\
\hline Israel & 3 \\
\hline Italy & 0 \\
\hline Ivory Coast & 7 \\
\hline
\end{tabular}




\begin{tabular}{|c|c|}
\hline Jamaica & 6 \\
\hline Japan & 0 \\
\hline Jordan & 5 \\
\hline Kazakhstan & 4 \\
\hline Kenya & 6 \\
\hline Kuwait & 2 \\
\hline Kyrgyzstan & 7 \\
\hline Laos & 7 \\
\hline Latvia & 3 \\
\hline Lebanon & 7 \\
\hline Lesotho & 6 \\
\hline Liberia & 7 \\
\hline Libya & 6 \\
\hline Lithuania & 2 \\
\hline Luxembourg & 0 \\
\hline Macau & 2 \\
\hline Macedonia & 5 \\
\hline Madagascar & 7 \\
\hline Malawi & 7 \\
\hline Malaysia & 2 \\
\hline Maldives & 5 \\
\hline Mali & 6 \\
\hline Malta & 2 \\
\hline Mauritania & 7 \\
\hline Mauritius & 3 \\
\hline Mexico & 2 \\
\hline Moldova & 7 \\
\hline Mongolia & 7 \\
\hline Morocco & 3 \\
\hline Mozambique & 6 \\
\hline Namibia & 3 \\
\hline Nepal & 7 \\
\hline Netherlands & 0 \\
\hline Netherlands Antilles & 5 \\
\hline New Zealand & 0 \\
\hline Nicaragua & 7 \\
\hline Niger & 6 \\
\hline Nigeria & 7 \\
\hline North Korea, Democratic Republic & 7 \\
\hline Norway & 0 \\
\hline Oman & 2 \\
\hline
\end{tabular}




\begin{tabular}{|c|c|}
\hline Pakistan & 6 \\
\hline Panama & 3 \\
\hline Papua New Guinea & 5 \\
\hline Paraguay & 6 \\
\hline Peru & 4 \\
\hline Philippines & 5 \\
\hline Poland & 2 \\
\hline Portugal & 0 \\
\hline Qatar & 2 \\
\hline Romania & 3 \\
\hline Russia & 3 \\
\hline Rwanda & 7 \\
\hline Saint Kitts and Nevis & 7 \\
\hline Saint Vincent and the Grenadines & 5 \\
\hline Sao Tome and Principe & 7 \\
\hline Saudi Arabia & 2 \\
\hline Senegal & 6 \\
\hline Serbia & 7 \\
\hline Seychelles & 7 \\
\hline Sierra Leone & 7 \\
\hline Singapore & 0 \\
\hline Slovakia & 1 \\
\hline Slovenia & 0 \\
\hline Somalia & 7 \\
\hline South Africa & 3 \\
\hline South Korea & 0 \\
\hline Spain & 0 \\
\hline Sri Lanka & 5 \\
\hline Sudan & 7 \\
\hline Suriname & 7 \\
\hline Swaziland & 6 \\
\hline Sweden & 0 \\
\hline Switzerland & 0 \\
\hline Syria & 7 \\
\hline Taiwan, China & 1 \\
\hline Tajikistan & 7 \\
\hline Tanzania & 6 \\
\hline Thailand & 3 \\
\hline Togo & 7 \\
\hline Trinidad and Tobago & 2 \\
\hline Tunisia & 3 \\
\hline
\end{tabular}




\begin{tabular}{|l|l|}
\hline Turkey & 5 \\
\hline Turkmenistan & 7 \\
\hline Uganda & 6 \\
\hline Ukraine & 5 \\
\hline United Arab Emirates & 2 \\
\hline United Kingdom & 0 \\
\hline United States & 0 \\
\hline Uruguay & 4 \\
\hline Uzbekistan & 7 \\
\hline Venezuela & 6 \\
\hline Vietnam & 4 \\
\hline Yemen & 6 \\
\hline Zambia & 6 \\
\hline Zimbabwe & 7 \\
\hline
\end{tabular}

Source: OECD 
ANNEXE 2: Long-term foreign currency sovereign ratings

\begin{tabular}{|c|c|c|c|}
\hline \multicolumn{4}{|c|}{ Long-term foreign currency sovereign ratings. 30 November 2007} \\
\hline \multirow[t]{2}{*}{ COUNTRY } & \multicolumn{3}{|c|}{ RATINGS } \\
\hline & MOODY'S & STANDARD \& POOR'S & FITCHRATINGS \\
\hline Albania & B1 & - & - \\
\hline Andorra & - & AA & - \\
\hline Argentina & B3 & $\mathrm{B}+$ & DDD \\
\hline Armenia & Ba2 & - & BB- \\
\hline Aruba & - & - & BBB \\
\hline Australia & Aaa & AAA & $\mathrm{AA}+$ \\
\hline Austria & Aaa & AAA & AAA \\
\hline Azerbaijan & Ba1 & - & $\mathrm{BB}+$ \\
\hline Bahamas & A3 & A- & - \\
\hline Bahrain & $\mathrm{A} 2$ & A & A \\
\hline Barbados & Baa2 & $\mathrm{BBB}+$ & - \\
\hline Belarus & B1 & $\mathrm{B}+$ & \\
\hline Belgium & Aa1 & $\mathrm{AA}+$ & $\mathrm{AA}+$ \\
\hline Belize & Caa1 & B & - \\
\hline Benin & - & B & B \\
\hline Bermuda & Aa1 & AA & $\mathrm{AA}+$ \\
\hline Bolivia & B3 & B- & $\mathrm{B}-$ \\
\hline Bosnia-Herzegovina & B2 & - & - \\
\hline Botswana & $\mathrm{A} 2$ & A & - \\
\hline Brazil & Ba1 & $\mathrm{BB}+$ & $\mathrm{BB}+$ \\
\hline Bulgaria & Baa3 & $\mathrm{BBB}+$ & BBB \\
\hline Burkina Faso & - & $\mathrm{B}$ & - \\
\hline Cambodia & B2 & $\mathrm{B}+$ & - \\
\hline Cameroon & - & $\mathrm{B}$ & $\mathrm{B}$ \\
\hline Canada & Aaa & AAA & AAA \\
\hline Cape Verde & - & - & $\mathrm{B}+$ \\
\hline Cayman Islands & Aa3 & - & - \\
\hline Chile & $\mathrm{A} 2$ & $\mathrm{~A}$ & A \\
\hline China & A1 & A & $A+$ \\
\hline Colombia & $\mathrm{Ba} 2$ & $\mathrm{BB}+$ & $\mathrm{BB}+$ \\
\hline Cook Islands & - & BB- & - \\
\hline Costa Rica & Ba1 & $\mathrm{BB}$ & $\mathrm{BB}$ \\
\hline Croatia & Baa3 & BBB & BBB- \\
\hline
\end{tabular}




\begin{tabular}{|c|c|c|c|}
\hline Cuba & Caa1 & - & - \\
\hline Cyprus & A1 & A & $A+$ \\
\hline Czech Republic & A1 & A & A \\
\hline Denmark & Aaa & AAA & AAA \\
\hline Dominican Republic & B2 & $\mathrm{B}+$ & B \\
\hline Ecuador & Caa2 & B- & $\mathrm{CCC}$ \\
\hline Egypt & $\mathrm{Ba} 1$ & BB+ & BB+ \\
\hline El Salvador & Baa3 & BB+ & BB+ \\
\hline Estonia & A1 & A & A \\
\hline Fiji & $\mathrm{Ba} 2$ & B & - \\
\hline Finland & Aaa & AAA & AAA \\
\hline France & Aaa & AAA & AAA \\
\hline Gabón & & BB- & BB- \\
\hline Georgia & - & B+ & BB- \\
\hline Germany & Aaa & AAA & AAA \\
\hline Ghana & - & $B+$ & $B+$ \\
\hline Greece & A1 & A & A \\
\hline Grenada & - & B- & - \\
\hline Guatemala & $\mathrm{Ba} 2$ & BB & BB+ \\
\hline Honduras & B2 & - & - \\
\hline Hong Kong & Aa2 & AA & $A A$ \\
\hline Hungary & A2 & BBB+ & BBB+ \\
\hline Iceland & Aaa & At & A+ \\
\hline India & Baa3 & BBB- & BBB- \\
\hline Indonesia & Ba3 & BB- & BB- \\
\hline Iran & - & - & $B+$ \\
\hline Ireland & Aaa & AAA & AAA \\
\hline Isle of Man & Aaa & AAA & - \\
\hline Israel & A2 & A & A- \\
\hline Italy & $\mathrm{Aa} 2$ & $A+$ & AA- \\
\hline Jamaica & B1 & B & $\mathrm{B}+$ \\
\hline Japan & Aaa & AA & AA \\
\hline Jordan & $\mathrm{Ba} 2$ & BB & - \\
\hline Kazakhstan & Baa2 & BBB- & BBB \\
\hline Kenya & - & $\mathrm{B}+$ & - \\
\hline Kuwait & $\mathrm{Aa} 2$ & AA- & AA- \\
\hline Latvia & $\mathrm{A} 2$ & $\mathrm{BBB}+$ & $\mathrm{BBB}+$ \\
\hline Lebanon & B3 & B- & B- \\
\hline Lesotho & - & - & BB- \\
\hline Liechtenstein & - & AAA & - \\
\hline Lithuania & A2 & A & A \\
\hline
\end{tabular}




\begin{tabular}{|c|c|c|c|}
\hline Luxembourg & Aaa & AAA & AAA \\
\hline Macau & $\mathrm{Aa} 3$ & - & - \\
\hline Macedonia & - & $\mathrm{BB}+$ & $\mathrm{BB}+$ \\
\hline Madagascar & - & B & - \\
\hline Malawi & - & - & B- \\
\hline Malaysia & A3 & $A-$ & A- \\
\hline Mali & - & B & B- \\
\hline Malta & A3 & A & A \\
\hline Mauritius & Baa2 & - & - \\
\hline Mexico & Baa1 & BBB+ & BBB+ \\
\hline Moldova & Caa1 & - & B- \\
\hline Mongolia & B1 & $B+$ & $\mathrm{B}+$ \\
\hline Montserrat & - & BBB- & - \\
\hline Montenegro & - & BB+ & - \\
\hline Morocco & $\mathrm{Ba} 1$ & $\mathrm{BB}+$ & BBB- \\
\hline Mozambique & - & B & B \\
\hline Namibia & - & - & BBB- \\
\hline Netherlands & Aaа & AAA & AAA \\
\hline New Zealand & Aaa & $\mathrm{AA}+$ & $\mathrm{AA}+$ \\
\hline Nicaragua & Caa1 & - & - \\
\hline Nigeria & - & BB- & BB- \\
\hline Norway & Aaa & AAA & AAA \\
\hline Oman & A2 & A & - \\
\hline Pakistan & B1 & $\mathrm{B}+$ & - \\
\hline Panama & $\mathrm{Ba} 1$ & BB & BB+ \\
\hline Papua New Guinea & B1 & $\mathrm{B}+$ & B \\
\hline Paraguay & Caa1 & B & - \\
\hline Peru & $\mathrm{Ba} 2$ & $\mathrm{BB}+$ & $\mathrm{BB}+$ \\
\hline Philippines & B1 & BB- & BB \\
\hline Poland & A2 & A- & A- \\
\hline Portugal & $\mathrm{Aa} 2$ & AA- & AA \\
\hline Qatar & Aa2 & AA- & - \\
\hline Romania & Baa3 & BBB- & BBB \\
\hline Russia & Baa2 & $\mathrm{BBB}+$ & $\mathrm{BBB}+$ \\
\hline Rwanda & - & - & B- \\
\hline San Marino & - & - & $A A$ \\
\hline Saudi Arabia & $\mathrm{A} 1$ & AA- & $A+$ \\
\hline Senegal & - & $\mathrm{B}+$ & - \\
\hline Serbia & - & BB- & BB- \\
\hline Seychelles & - & B & - \\
\hline Singapore & Aaa & AAA & AAA \\
\hline
\end{tabular}




\begin{tabular}{|c|c|c|c|}
\hline Slovakia & A1 & $A$ & $A$ \\
\hline Slovenia & Aa2 & $A A$ & $A A$ \\
\hline South Africa & Baa1 & $\mathrm{BBB}+$ & $\mathrm{BBB}+$ \\
\hline South Korea & $\mathrm{A} 2$ & $A$ & $A+$ \\
\hline Spain & Aaa & AAA & AAA \\
\hline Sri Lanka & - & $\mathrm{B}+$ & BB- \\
\hline Suriname & B1 & $\mathrm{B}+$ & $B$ \\
\hline Sweden & Aaa & AAA & AAA \\
\hline Switzerland & Aaa & AAA & AAA \\
\hline Taiwan, China & Aa3 & AA- & $A+$ \\
\hline Thailand & Baa1 & $\mathrm{BBB}+$ & $\mathrm{BBB}+$ \\
\hline Trinidad and Tobago & Baa1 & $A-$ & - \\
\hline Tunisia & Baa2 & BBB & BBB \\
\hline Turkey & Ba3 & BB- & BB- \\
\hline Turkmenistan & B2 & - & - \\
\hline Uganda & - & - & $B$ \\
\hline Ukraine & B1 & BB- & BB- \\
\hline United Arab Emirates & Aa2 & - & - \\
\hline United Kingdom & Aaa & AAA & AAA \\
\hline United States & Aaa & AAA & AAA \\
\hline Uruguay & B1 & $\mathrm{B}+$ & BB- \\
\hline Venezuela & B2 & BB- & BB- \\
\hline Vietnam & $\mathrm{Ba3}$ & BB & BB- \\
\hline
\end{tabular}

Source: Moody's, Standard \& Poor's and FitchRatings. 


\section{ANNEXE 3: Circular 4/2004, of 22 December (Annexe IX)}

Anejo IX de la Circular 4/2004, de 22 de diciembre, a entidades de crédito, sobre normas de información financiera pública y reservada y modelos de estados financieros (BOE 30 diciembre 2004).

\section{ANÁLISIS Y COBERTURA DEL RIESGO DE CRÉDITO}

\section{INTRODUCCIÓN}

1. Las entidades establecerán las políticas, métodos y procedimientos que aplicarán en la concesión, estudio y documentación de sus instrumentos de deuda, riesgos contingentes y compromisos contingentes (en adelante operaciones), así como en la identificación de su deterioro y del cálculo de los importes necesarios para la cobertura de su riesgo de crédito, tanto por insolvencia atribuible al cliente como por riesgo-país, para todas las entidades del grupo, españolas y extranjeras.

Las políticas, métodos y procedimientos deberán:

a) Ser aprobados por el Consejo de Administración, u órgano equivalente de la entidad, y ratificados por la entidad dominante en el caso de entidades dependientes de grupos españoles.

b) Estar adecuadamente justificados y documentados. Entre la documentación necesaria se deberán incluir las propuestas y dictámenes de los correspondientes departamentos internos de la entidad.

c) Detallar entre otras cuestiones:

(i) Los criterios para la concesión de operaciones, entre los que se incluirán cuestiones tales como los mercados, productos, tipo de clientela, etc., en los que se va a operar, así como los límites globales de los riesgos que se vayan a asumir para cada uno de ellos, y los requisitos que deben cumplir los clientes y las garantías para concederles las operaciones.

(ii) La política de precios a aplicar.

(iii) Las responsabilidades y facultades delegadas de los diferentes órganos y personas encargadas de la concesión, formalización, seguimiento, valoración y control de las operaciones.

(iv) Los requisitos que deberán reunir los estudios y análisis de las operaciones a realizar antes de su concesión y durante su vigencia.

(v) La documentación mínima que deben tener los diferentes tipos de operaciones para su concesión y durante su vigencia.

(vi) La definición de los criterios para clasificar las operaciones en función de su riesgo de crédito y la forma de cuantificar las estimaciones individuales y colectivas de las pérdidas por deterioro, incluidos en éste último caso los parámetros a utilizar en la estimación.

La Comisión de Auditoría y el Departamento de Auditoría Interna velarán por que las políticas, métodos y procedimientos sean adecuados, se implanten efectivamente y se revisen regularmente.

La documentación a la que se refiere este apartado estará a disposición del Banco de España y de los auditores externos.

2. Las entidades deberán aplicar, en todo caso, los siguientes criterios:

a) Pondrán el máximo cuidado y diligencia en el estudio riguroso e individualizado del riesgo de crédito de las operaciones, no sólo en el momento de su concesión sino también continuamente durante su vigencia, y no retrasarán su reclasificación a una categoría peor por empeoramiento de la calidad crediticia, ni su cobertura adecuada, las cuales se deberán realizar tan pronto se aprecie la existencia de una situación anormal o de deterioro del riesgo de crédito.

b) Documentarán adecuadamente todas las operaciones. Dicha documentación incluirá, como mínimo: los contratos firmados con los clientes y, en su caso, garantes, debidamente verificados para comprobar que no presentan defectos jurídicos que puedan perjudicar la recuperación de la operación; la información necesaria para poder determinar el valor razonable de las garantías que se hubiesen recibido, incluyendo las oportunas tasaciones, que se deberán actualizar, al menos cuando existan indicios de que puede haber un deterioro de su valor; e información económico-financiera que permita analizar la solvencia y capacidad de pago de los clientes y garantes. Cuando éstos sean empresas, dicha información comprenderá sus estados financieros debidamente actualizados. No obstante lo anterior, no será necesario que se actualice la documentación de aquellos clientes con riesgos vivos por importes inferiores a 150.000 euros, exclusivamente por operaciones de arrendamiento financiero o que cuenten con garantías eficaces, siempre que no tengan importes impagados ni exista algún indicio de que el cliente tenga problemas, y el valor estimado, con cualquier criterio objetivo, de los bienes cedidos en arrendamiento $o$ de las garantías eficaces sea superior al riesgo pendiente de vencimiento. 
c) Los métodos y procedimientos que utilicen para la estimación del deterioro por riesgo de crédito estarán integrados en el sistema de gestión del riesgo de las entidades y deberán tener en cuenta, además de todos los factores enumerados en el apartado 2 de la norma vigésima novena, la experiencia pasada, las áreas geográficas y de negocio en las que se desenvuelve la actividad de la entidad y del grupo, los niveles de riesgo y toda la información disponible a la fecha en la que se realice la estimación.

d) En el análisis del riesgo de crédito y en la estimación de las pérdidas por deterioro de los activos financieros disponibles para la venta se considerará el efectivo desembolsado por la entidad pendiente de amortización, en lugar de su valor razonable.

3. Las entidades dominantes de grupos de entidades de crédito o, en su caso, de grupos consolidables de entidades de crédito, con entidades dependientes extranjeras implantarán una metodología corporativa para la clasificación del riesgo de crédito y unos criterios para el cálculo de las pérdidas por su deterioro similares a las contemplados en este anejo para las entidades españolas, aunque adaptados a las circunstancias particulares del país en el que operen sus entidades dependientes.

\section{CLASIFICACIÓN DE LAS OPERACIONES EN FUNCIÓN DEL RIESGO DE CRÉDITO}

4. Las carteras de instrumentos de deuda, riesgos contingentes y compromisos contingentes, cualquiera que sea su titular, instrumentación o garantía, se analizarán para determinar el riesgo de crédito al que está expuesta la entidad y estimar las necesidades de cobertura por deterioro de su valor. Para ello, las entidades fijarán unos criterios corporativos para la calificación de sus riesgos.

5. Para la confección de los estados financieros, las entidades clasificarán sus operaciones en función de su riesgo de crédito analizando, por un lado, el riesgo de insolvencia imputable al cliente y, por otro, el riesgo-país al que, en su caso, estén expuestas, aplicando los criterios indicados en este anejo, sin perjuicio del mayor detalle que puedan establecer para su control interno y, en el supuesto de entidades dependientes extranjeras, de que se tengan en cuenta las características particulares del mercado en el que operen.

6. Las operaciones en las que concurran razones para calificar una operación por riesgo de crédito, tanto por riesgo imputable al cliente como riesgo-país, se clasificarán en la categoría correspondiente al riesgo imputable al cliente, salvo que le corresponda una categoría peor por riesgo-país, sin perjuicio de que las pérdidas por deterioro imputables al riesgo cliente se cubran por el concepto de riesgo-país cuando implique mayor exigencia.

\section{A) RIESGO DE INSOLVENCIA DEL CLIENTE}

7. Los instrumentos de deuda no valorados por su valor razonable con cambios en la cuenta de pérdidas y ganancias, así como los riesgos contingentes y los compromisos contingentes mencionados en las siguientes letras c) y d), se clasificarán, en función del riesgo de insolvencia imputable al cliente o a la operación, en alguna de las siguientes categorías:

a) Riesgo normal: Comprende todos los instrumentos de deuda y riesgos contingentes que no cumplan los requisitos para clasificarlos en otras categorías. Las operaciones incluidas en esta categoría se subdividirán a su vez en las siguientes clases de riesgo:

(i) Sin riesgo apreciable. Comprende las siguientes operaciones: los riesgos con las Administraciones Públicas de países de la Unión Europea, incluidos los derivados de adquisiciones temporales de deuda pública, las sociedades no financieras públicas a que se refiere la norma sexagésima sexta, apartado 7.b.(i) y las Administraciones Centrales de países clasificados en el grupo 1 a efectos de riesgo-país; las avaladas o reafianzadas por dichas Administraciones Públicas, directa, o indirectamente a través de organismos con garantía ilimitada de las mismas; los anticipos sobre pensiones y nóminas correspondientes al mes siguiente, siempre que la entidad pagadora sea una Administración Pública y las mismas estén domiciliadas en la entidad; las aseguradas, avaladas o reafianzadas por organismos o empresas públicas de países clasificados en el grupo 1 a efectos de riesgo país cuya actividad principal sea el aseguramiento o aval de crédito, en la parte cubierta; las que estén a nombre de las entidades de crédito; las que cuenten con garantía personal plena, solidaria, explícita e incondicional otorgada por las entidades de crédito mencionadas anteriormente y por sociedades de garantía recíproca españolas que se puedan reclamar a primer requerimiento; los riesgos a nombre de Fondos de Garantía de Depósitos, siempre que sean homologables por su calidad crediticia a los de los de la Unión Europea; las garantizadas con depósitos dinerarios o que cuenten con garantía pignoraticia de participaciones en instituciones financieras monetarias 0 de valores representativos de deuda emitidos por las Administraciones Públicas o entidades de crédito, cuando el riesgo vivo sea igual o inferior al 90 por ciento del valor de rescate de las participaciones en instituciones financieras monetarias y del valor de mercado de los valores recibidos en garantía.

(ii) Riesgo bajo. Comprende las siguientes operaciones: los activos que sirvan de garantía en las operaciones de política monetaria del Sistema Europeo de Bancos Centrales, salvo los incluidos en el punto (i) anterior; las operaciones con garantía real sobre viviendas terminadas o arrendamientos financieros sobre tales bienes cuyo riesgo vivo sea inferior al $80 \%$ del valor de tasación de las viviendas; los bonos de titulización hipotecarios ordinarios; las operaciones cuyo titular sea una empresa cuyas deudas a largo plazo estén calificadas, al menos, con una A por alguna agencia de calificación de reconocido prestigio; y los valores emitidos en moneda local por Administraciones Centrales de países no clasificados en el 
grupo 1 a efectos de riesgo-país que estén registrados en los libros de sucursales radicadas en el país del emisor.

(iii) Riesgo medio-bajo. Comprende las siguientes operaciones: las operaciones de arrendamiento financiero no incluidas en otras clases de riesgo y los riesgos que cuenten con alguna garantía real diferente de las indicadas en los riesgos enumerados en los puntos anteriores, siempre que el valor estimado de los bienes cedidos en arrendamiento financiero y de las garantías reales cubra plenamente el riesgo vivo.

(iv) Riesgo medio. Comprende los riesgos con residentes en España o en países incluidos en los grupos 1 y 2 a efectos de riesgo-país, no incluidos en las clases de riesgo anteriores, salvo que cumplan los criterios para clasificarlos en las clases de riesgo medio-alto o riesgo alto.

(v) Riesgo medio-alto. Comprende las siguientes operaciones, salvo que cumplan los criterios para clasificarlas en la clase de riesgo alto: los créditos a personas físicas para la adquisición de bienes de consumo duradero y de otros bienes y servicios corrientes, no afectos a una actividad empresarial, salvo que estén inscritos en el Registro de Ventas a Plazo de Bienes Muebles, y los riesgos con obligados finales residentes en países incluidos en los grupos 3 a 6 a efectos de riesgo-país excluidos de cobertura de dicho riesgo, que no estén comprendidos en otras clases.

(vi) Riesgo alto. Comprende las siguientes operaciones: los saldos por tarjetas de crédito, descubiertos en cuenta corriente y excedidos en cuenta de crédito cualquiera que sea su titular, excepto los mencionados en los puntos (i) y (ii) anteriores.

Dentro de esta categoría será necesario identificar las operaciones que merecen un seguimiento especial, entendiendo por tales aquellas que presentan pequeñas debilidades que, sin llegar a exigir mayores coberturas que las establecidas para las operaciones de riesgo normal, aconsejan un seguimiento especial por la entidad. Entre las operaciones a identificar como con seguimiento especial se incluirán: hasta su extinción, los riesgos reestructurados (prorrogados, reinstumentados o correspondientes a clientes declarados en convenio de acreedores que se hubiesen reclasificado desde alguna de las categorías de dudosos por cumplir los requisitos señalados en ellas; y las operaciones clasificadas como normales de clientes que tengan alguna operación clasificada como dudosa por razón de morosidad.

b) Riesgo subestándar. Comprende todos los instrumentos de deuda y riesgos contingentes que, sin cumplir los criterios para clasificarlos individualmente como dudosos o fallidos, presentan debilidades que pueden suponer asumir pérdidas por la entidad superiores a las coberturas por deterioro de los riesgos en seguimiento especial. En esta categoría se incluyen, entre otras: las operaciones de clientes que forman parte de colectivos en dificultades (tales como los residentes en una determinada área geográfica con un ámbito inferior al país, o los pertenecientes a un sector económico concreto, que estén atravesando dificultades económicas), para los que se estiman pérdidas globales superiores a las que corresponden a las categorías descritas en las letras anteriores, y las operaciones no documentadas adecuadamente.

c) Riesgo dudoso por razón de la morosidad del cliente. Comprende el importe total de los instrumentos de deuda, cualquiera que sea su titular y garantía, que tengan algún importe vencido por principal, intereses o gastos pactados contractualmente, con más de tres meses de antigüedad, salvo que proceda clasificarlos como fallidos; y los riesgos contingentes en los que el avalado haya incurrido en morosidad.

También se incluirán en esta categoría los importes de todas las operaciones de un cliente cuando los saldos clasificados como dudosos por razón de morosidad sean superiores al $25 \%$ de los importes pendientes de cobro. A los solos efectos de la determinación del porcentaje señalado, se considerarán, en el numerador, los saldos dinerarios vencidos e impagados por principal, intereses o gastos de las operaciones dudosas por razón de la morosidad o fallidas, y en el denominador, la totalidad de los riesgos dinerarios pendientes de cobro, excluidos los intereses no devengados. Si el porcentaje así calculado supera el $25 \%$, se traspasarán a dudosos por razón de la morosidad tanto los riesgos dinerarios como los riesgos contingentes contraídos con el cliente, salvo los avales no financieros.

En los descubiertos y demás saldos deudores a la vista sin vencimiento pactado, el plazo para computar la antigüedad de los importes impagados se contará desde el primer requerimiento de reembolso que efectúe la entidad, o desde la primera liquidación de intereses que resulte impagada.

En las operaciones con cuotas de amortización periódica, la fecha del primer vencimiento a efectos de la clasificación de las operaciones en esta categoría será la correspondiente a la de la cuota más antigua de la que, en la fecha del balance, permanezca impagado algún importe por principal o intereses.

Las operaciones clasificadas en esta categoría se podrán reclasificar a riesgo normal si, como consecuencia del cobro de parte de las cuotas impagadas, desaparecen las causas que motivaron su clasificación como activos dudosos de acuerdo con lo indicado en los párrafos anteriores, salvo que subsistan otras razones para clasificarlas como dudosas.

La prórroga o reinstrumentación de las operaciones no interrumpe su morosidad, ni producirá su reclasificación a una de las categorías anteriores, salvo que exista una razonable certeza de que el cliente puede hacer frente a su pago en el calendario previsto o se aporten nuevas garantías eficaces, y, en ambos casos, se perciban, al 
menos, los intereses ordinarios pendientes de cobro, sin tener en cuenta los intereses de demora.

A los efectos del párrafo anterior, se consideran garantías eficaces las siguientes: garantías pignoraticias sobre depósitos dinerarios, instrumentos de capital cotizados y valores representativos de deuda emitidos por emisores de reconocida solvencia; garantías hipotecarias sobre viviendas, oficinas y locales polivalentes terminados y fincas rústicas, deducidas, en su caso, las cargas previas; y garantías personales (avales, fianzas, incorporación de nuevos titulares, etc.) que impliquen la responsabilidad directa y solidaria de nuevos garantes ante la entidad, que sean personas o entidades cuya solvencia patrimonial esté lo suficientemente contrastada como para asegurar el reembolso total de la operación en los términos acordados. El importe de estas garantías ha de cubrir plenamente el riesgo que garanticen.

Se considera que tienen carácter polivalente todas las oficinas y locales que, sin alteración estructural o arquitectónica, sean susceptibles de utilización para distintas actividades empresariales y por parte de distintas empresas o agentes económicos, sin que existan limitaciones legales o administrativas que restrinjan apreciablemente su uso o la posibilidad de su venta.

d) Riesgo dudoso por razones distintas de la morosidad del cliente. Comprende los instrumentos de deuda, vencidos o no, en los que, sin concurrir las circunstancias para clasificarlos en las categorías de fallidos o dudosos por razón de la morosidad del cliente, se presenten dudas razonables sobre su reembolso total (principal e intereses) en los términos pactados contractualmente; así como los riesgos contingentes y compromisos contingentes no calificados como dudosos por razón de la morosidad del cliente cuyo pago por la entidad sea probable y su recuperación dudosa.

En esta categoría se incluirían, entre otras: las operaciones de los clientes en situaciones que supongan un deterioro de su solvencia, tales como patrimonio negativo, pérdidas continuadas, retraso generalizado en los pagos, estructura económica o financiera inadecuada, flujos de caja insuficientes para atender las deudas o imposibilidad de obtener financiaciones adicionales; los saldos reclamados y aquellos sobre los que se haya decido reclamar judicialmente su reembolso por la entidad, aunque estén garantizados; las operaciones sobre las que el deudor haya suscitado litigio de cuya resolución dependa su cobro; las operaciones de arrendamiento financiero en las que la entidad haya decidido rescindir el contrato para recuperar la posesión del bien; las operaciones de los clientes que estén declarados o conste que se van a declarar en concurso de acreedores sin petición de liquidación, así como el conjunto de las operaciones (incluidos los riesgos y compromisos contingentes para los que se estime que se tengan que realizar desembolsos) de los clientes con algún saldo calificado como dudoso por razón de su morosidad que no alcancen el porcentaje señalado en letra c) anterior, si después de su estudio individualizado se concluye que existen dudas razonables sobre su reembolso total (principal e intereses). También se incluirán los riesgos contingentes de los avalados declarados en concurso de acreedores para los que conste que se haya declarado o se vaya a declarar la fase de liquidación, o sufran un deterioro notorio e irrecuperable de su solvencia, aunque el beneficiario del aval no haya reclamado su pago. Los riesgos de clientes declarados en convenio de acreedores sin petición de liquidación se reclasificarán a la categoría de riesgo normal cuando el acreditado haya pagado, al menos, el $25 \%$ de los créditos de la entidad afectados por la suspensión de pagos -una vez descontada, en su caso, la quita acordada-, o hayan transcurrido 2 años desde la inscripción en el Registro Mercantil del auto de aprobación del convenio de acreedores, siempre que dicho convenio se esté cumpliendo fielmente y la evolución de la situación patrimonial y financiera de la empresa elimine las dudas sobre el reembolso total de los débitos. Los riesgos en los que se incurra con posterioridad a la aprobación del convenio de acreedores no necesitarán calificarse como dudosos en tanto se cumpla el convenio y no se tengan dudas razonables sobre su cobro.

e) Riesgo fallido. En esta categoría se incluirá el importe de los instrumentos de deuda, vencidos o no, para los que después de un análisis individualizado se considere remota su recuperación y proceda darlos de baja del activo. Salvo prueba en contrario, en esta categoría se incluirían todos los débitos, excepto los importes cubiertos con garantías eficaces suficientes, de los clientes que estén declarados en concurso de acreedores para los que conste que se haya declarado o se vaya declarar la fase de liquidación, o sufran un deterioro notorio e irrecuperable de su solvencia, y los saldos de las operaciones clasificadas como dudosas por razón de morosidad con una antigüedad superior a cuatro años.

La clasificación en esta categoría no implica que la entidad interrumpa las negociaciones y actuaciones legales para recuperar su importe.

\section{B) RIESGO DE CRÉDITO POR RAZÓN DE RIESGO-PAÍS}

8. Los instrumentos de deuda no valorados por su valor razonable con cambios en la cuenta de pérdidas y ganancias, así como los riesgos contingentes, cualquiera que sea el cliente, se analizarán para determinar su riesgo de crédito por razón de riesgo-país.

A estos efectos, por riesgo-país se entiende el riesgo que concurre en los clientes residentes en un determinado país por circunstancias distintas del riesgo comercial habitual. El riesgopaís comprende el riesgo soberano, el riesgo de transferencia y los restantes riesgos derivados de la actividad financiera internacional según se definen a continuación: 
a) Riesgo soberano es el de los acreedores de los estados o de entidades garantizadas por ellos, en cuanto pueden ser ineficaces las acciones legales contra el prestatario o último obligado al pago por razones de soberanía.

b) Riesgo de transferencia es el de los acreedores extranjeros de los residentes de un país que experimenta una incapacidad general para hacer frente a sus deudas, por carecer de la divisa o divisas en que estén denominadas.

c) Restantes riesgos derivados de la actividad financiera internacional son los resultantes de alguna de las situaciones siguientes: guerra civil o internacional, revolución, cualquier acontecimiento similar o de carácter catastrófico; los acontecimientos de especial gravedad políticos o económicos, como las crisis de balanza de pagos o las alteraciones significativas de la paridadmonetaria que originen una situación generalizada de insolvencia; la expropiación, nacionalización o incautación dictadas por autoridades extranjeras, y las medidas expresas o tácitas adoptadas por un gobierno extranjero o por las autoridades españolas que den lugar al incumplimiento de los contratos.

9. Las operaciones se asignarán al país de residencia del cliente a la fecha del análisis, salvo en los siguientes casos en los que se clasificarán como se indica a continuación:

a) Los que estén garantizados por residentes de otro país mejor clasificado, o por CESCE u otros residentes en España, por la parte garantizada, que se clasificarán en el grupo que corresponda incluir al garante siempre que éste tenga capacidad financiera suficiente para hacer frente a los compromisos asumidos.

b) Los que tengan garantías reales, por la parte garantizada, siempre que la garantía sea suficiente, y la cosa objeto de la garantía se encuentre y sea realizable en España u otro país del grupo 1, que se clasificarán entre los riesgos del grupo 1.

c) Los riesgos con sucursales en el extranjero de una entidad, que se clasificarán en función de la situación del país de residencia de la sede central de dichas sucursales.

10. Los instrumentos de deuda y riesgos contingentes se clasificarán en función de su riesgo-país en los grupos 1 a 6 que se indican en este apartado. Para ello, las entidades realizarán una apreciación global del riesgo de los países a los que se imputen las operaciones en función de su evolución económica, situación política, marco regulatorio e institucional, y capacidad y experiencia de pagos. A estos efectos, tendrán en cuenta los siguientes indicadores relativos al país:

a) La experiencia de pagos, con especial atención, en su caso, al cumplimiento de los acuerdos de renegociación y a los pagos a realizar a las instituciones financieras internacionales.

b) La situación financiera externa, teniendo en cuenta especialmente, los indicadores de deuda externa total, deuda externa a corto plazo, servicio de la deuda con respecto al Producto Interior Bruto y a las exportaciones, y las reservas exteriores.

c) La situación económica, basándose fundamentalmente en:

(i) Indicadores relativos a los agregados presupuestarios, monetarios y de balanza de pagos.

(ii) Indicadores relativos al crecimiento económico (nivel de renta, tasas de ahorro o de inversión, crecimiento del PIB, etc.) y de vulnerabilidad (diversificación de las exportaciones, dependencia de la ayuda, etc.).

d) Indicadores de mercado, en especial, se tendrán en cuenta las calificaciones crediticias efectuadas por agencias de calificación de reconocido prestigio, las cotizaciones de las deudas en el mercado secundario, el acceso a los mercados y los diferenciales de tipo de interés de la deuda.

Las operaciones se clasificarán en los siguientes grupos teniendo en cuenta la importancia relativa de los indicadores anteriores:

(a) Grupo 1. En este grupo se incluirán las operaciones con obligados finales residentes en países de la Unión Europea, Noruega, Suiza, Islandia, Estados Unidos, Canadá, Japón, Australia y Nueva Zelanda.

(b) Grupo 2. En este grupo se incluirán las operaciones con obligados finales residentes en países, que aún siendo de bajo riesgo, no estén incluidos en el grupo 1.

(c) Grupo 3. En este grupo se incluirán, al menos, las operaciones con obligados finales residentes en países que presenten un deterioro macroeconómico significativo que se estime que pueda afectar a la capacidad de pago del país. El citado deterioro puede manifestarse a través de: déficit significativos y persistentes en la balanza de pagos por cuenta corriente, proporciones altas de la deuda a corto plazo respecto a la deuda externa total o a las reservas exteriores netas, depreciaciones intensas del tipo de cambio o alteraciones importantes en el régimen cambiario (tales como abandono o riesgo inminente de abandono de arreglos monetarios como currency boards o sistemas de flotación controlada de la divisa), fuertes caídas en los precios de las bolsas de valores, ratios de deuda externa y de servicio de esa deuda muy superiores a los de los países clasificados en los grupos 1 y 2 o los de países de su entorno.

(d) Grupo 4. En este grupo se incluirán, al menos, las operaciones con obligados finales residentes en países que presenten un deterioro macroeconómico profundo que se estime que pueda afectar seriamente a la capacidad de pago del país. En este grupo se incluirán las operaciones imputadas a países clasificados en el grupo 3 que sufran un empeoramiento en los indicadores mencionados en la letra anterior.

(e) Grupo 5. En este grupo se incluirán las operaciones con obligados finales residentes en países que presenten dificultades prolongadas para hacer frente al servicio de su deuda, considerándose dudosa la posibilidad de recobro.

(f) Grupo 6. En esta categoría se incluirán las operaciones cuya recuperación se considere remota debido a las circunstancias imputables al país. En todo caso, en este grupo se incluirán las operaciones con obligados finales residentes en países que hayan repudiado 
sus deudas o no hayan atendido su amortización ni el pago de intereses durante cuatro años.

Las operaciones con organismos multilaterales integrados por países clasificados en los grupos 3,4 y 5 se clasificarán en el grupo en que se sitúe el mayor número de los países participantes, salvo los bancos multilaterales de desarrollo enumerados en la norma decimotercera, apartado 1.II.a), de la Circular 5/1993, de 26 de marzo, que se clasificarán en el grupo 1. Si hubiese razones objetivas para una mejor clasificación, se elevará consulta razonada al Banco de España proponiendo la que se estime procedente.

11. Los instrumentos de deuda y riesgos contingentes clasificados en los grupos 3 a 6 , salvo las operaciones excluidas de cobertura por riesgo-país según lo dispuesto en el siguiente apartado, se clasificarán a efectos de la estimación del deterioro por razón de riesgo-país en las siguientes categorías:

a) Riesgo subestándar por riesgo-país: Las operaciones clasificadas en los grupos 3 y 4 , salvo que las operaciones se deban clasificar como dudosas o fallidas por riesgo imputable al cliente.

b) Riesgo dudoso por riesgo-país: Las operaciones clasificadas en el grupo 5 y los riesgos contingentes y compromisos contingentes clasificados en el grupo 6 , salvo que se deban clasificar como dudosos o fallidos por riesgo imputable al cliente.

c) Riesgo fallido por riesgo-país: Las operaciones clasificadas en el grupo 6, salvo que las operaciones se deban clasificar como fallidas por riesgo imputable al cliente. Los instrumentos de deuda clasificados en esta categoría se darán de baja del activo.

12. Los siguientes instrumentos de deuda y riesgos contingentes se excluirán de cobertura por riesgopaís:

a) Los riesgos imputados a un país, cualquiera que sea la moneda en la que estén denominados, registrados en entidades dependientes y multigrupo radicadas en el país de residencia del titular; los riesgos en moneda local cualquiera que sea el titular registrados en sucursales radicadas en el país de residencia del titular; y los riesgos que no sean frente a Administraciones Públicas denominados en la moneda del país del titular registrados en los estados financieros de sucursales o entidades dependientes o multigrupo radicadas en un país diferente al de residencia del titular.

b) Los créditos comerciales, dinerarios o no, y los financieros derivados de los mismos, con vencimiento no superior a un año desde la fecha de utilización del crédito inicial.

c) Los créditos de prefinanciación con plazos iguales o inferiores a seis meses sobre contratos de exportación específicos, siempre que los citados créditos tengan como vencimiento la fecha de la exportación.

d) Las operaciones interbancarias con las sucursales radicadas en Estados miembros del Espacio Económico Europeo de entidades de crédito extranjeras localizadas en otros países, siempre que dichas sucursales en sus estados financieros para la cobertura de su riesgo de crédito apliquen criterios equiparables a los señalados en este anejo.

e) Las operaciones del sector privado de países pertenecientes a la zona monetaria de una divisa emitida por un país clasificado en el grupo 1.

f) Los activos financieros de cualquier clase, adquiridos para su colocación a terceros en el marco de una cartera gestionada separadamente con este propósito, con menos de seis meses en poder de la entidad.

\section{COBERTURA DE LA PÉRDIDA POR DETERIORO DEL RIESGO DE CRÉDITO}

13. Las entidades en el cálculo de los importes necesarios para la cobertura del riesgo de crédito aplicarán los siguientes criterios:

a) Calcularán conforme a lo dispuesto en este anejo el importe necesario para la cobertura, por un lado, del riesgo de insolvencia imputable al cliente y, por otro, del riesgo-país. Cuando se den simultáneamente razones para la cobertura de una operación por ambos tipos de riesgo, se aplicarán los criterios de cobertura más exigentes que puedan corresponderle.

b) Las entidades desarrollarán modelos internos para calcular las coberturas a realizar por los conceptos de riesgo de insolvencia y riesgo-país, que tomarán como referencia obligatoria la metodología que se describe en los siguientes apartados. Dichos modelos deberán formar parte de un sistema adecuado de medición y gestión del riesgo de crédito y utilizar parámetros obtenidos de datos procedentes de la base histórica de la entidad, que deberá abarcar un ciclo económico completo y no estar sesgada por un crecimiento del negocio que afecte a su representatividad. Cuando el Banco de España establezca los restantes requisitos mínimos que deben cumplir los modelos y previa verificación de conformidad, las entidades podrían utilizar sus modelos internos para la confección de sus estados financieros.

c) Las coberturas a realizar a los activos financieros transferidos que permanezcan en el balance por no cumplir los requisitos que establece la norma vigésima tercera para darlos de baja serán los que correspondan a dichos activos con el límite de las pérdidas que como máximo asuma la entidad.

d) Los valores de tasación de los bienes inmuebles localizados en España serán los que figuren en informes realizados por sociedades de tasación inscritas en el Registro Oficial del Banco de España aplicando los criterios que establece la Orden ECO/805/2003, de 27 de marzo. En los supuestos de ejecución de las garantías y cuando se haya producido un deterioro evidente en los bienes inmuebles, dichos informes se actualizarán y realizarán por una sociedad de tasación independiente de acuerdo con los criterios señalados en el apartado 5 de la norma decimacuarta.

e) En los estados consolidados, las coberturas de las pérdidas por deterioro del riesgo de crédito existentes en los balances oficiales de las entidades dependientes en el extranjero calculadas de acuerdo con la normativa local vigente, con opinión sin salvedades por los 
auditores externos, no se podrán liberar; sin perjuicio, de que deban realizarse coberturas adicionales en caso de que no sean suficientes de acuerdo con los criterios fijados por esta Circular.

f) El conjunto de las coberturas existentes en todo momento será la suma de las correspondientes a las pérdidas por operaciones específicas (cobertura específica) y a las pérdidas inherentes o no asignadas específicamente (cobertura genérica) correspondientes al riesgo de insolvencia del cliente, más la cobertura por riesgo-país.

\section{A) COBERTURA DEL RIESGO DE INSOLVENCIA DEL CLIENTE}

\section{Cobertura específica}

\subsection{Instrumentos de deuda}

14. Los instrumentos de deuda no valorados por su valor razonable con registro de las variaciones de valor en la cuenta de pérdidas y ganancias clasificados como dudosos se cubrirán de acuerdo con los criterios que se indican en los siguientes apartados.

\subsubsection{Activos dudosos por razón de la morosidad del cliente}

15. Las entidades evaluarán los activos calificados como dudosos por razón de la morosidad del cliente de manera individualizada, en especial los de cuantía significativa, para estimar las coberturas por deterioro, teniendo en cuenta la antigüedad de los importes impagados, las garantías aportadas y la situación económica del cliente y garantes.

Adicionalmente, las entidades desarrollarán métodos para el cálculo de coberturas colectivas para estos activos en los que los importes se determinarán en función de la antigüedad de los impagos. Para ello, las entidades clasificarán sus activos en función de la antigüedad de las cuotas impagadas y de las garantías existentes, y mantendrán bases de datos estadísticas históricas sobre su evolución y resultado final.

16. El Banco de España, sobre la base de su experiencia y de la información que tiene del sector bancario español, ha estimado los porcentajes mínimos de cobertura por calendario de morosidad que se indican en los siguientes apartados. Los porcentajes de cobertura incluidos en dichos calendarios de morosidad tienen en cuenta el valor temporal del dinero. Las entidades deberán aplicar, al menos, dichos porcentajes en la estimación de las coberturas específicas para la evaluación colectiva de las pérdidas correspondientes a las operaciones registradas en entidades españolas y de las registradas a nombre de residentes españoles en entidades dependientes extranjeras. El Banco de España actualizará periódicamente dichos calendarios de acuerdo con la evolución de los datos del sector, mediante la modificación correspondiente de esta Circular.

Para la estimación de la cobertura especifica correspondiente a operaciones con no residentes en España registradas en entidades dependientes extranjeras, se aplicarán los métodos y criterios que se indican en los siguientes apartados, utilizando calendarios de morosidad adaptados a las circunstancias particulares del país en el que opere la entidad dependiente. A estos efectos, las entidades tomarán como referencia exigible las escalas que se incluyen en el siguiente apartado.

17. Los activos calificados como dudosos por razón de la morosidad del cliente, salvo los regulados en los siguientes apartados, se cubrirán aplicando los porcentajes que se indican a continuación en función del tiempo transcurrido desde el vencimiento de la primera cuota o plazo que permanezca impagado de una misma operación:

a) Operaciones sin garantía real

Los porcentajes de cobertura aplicables a las operaciones distintas de las enumeradas entre las clases de riesgo como "sin riesgo apreciable", siempre que no cuenten con alguna de las garantías mencionadas en la letra b) ni en el siguiente apartado, serán las que se señalan a continuación, distinguiendo según que el cliente sea una empresa o empresario individual u otro tipo de cliente:

Empresas y empresarios Resto de clientela

Hasta 6 meses 5,3\% 4,5\%

Más de 6 meses, sin exceder de $1227,8 \% 27,4 \%$

Más de 12 meses, sin exceder de $1865,1 \% 60,5 \%$

Más de 18, sin exceder de 24 95,8\% 93,3\%

Más de 24 meses $100 \% 100 \%$

La escala anterior se aplicará a las operaciones clasificadas como dudosas por morosidad del cliente por acumulación de importes morosos en otras operaciones. A estos efectos, se considerará como fecha para el cálculo del porcentaje de cobertura de estas operaciones la del importe vencido más antiguo que permanezca impagado, o la de la calificación de los activos como dudosos si es anterior.

Cuando no sea posible identificar las operaciones que realizan las personas físicas en su calidad de empresarios, se les aplicarán a todas sus operaciones los porcentajes establecidos para el resto de la clientela.

b) Operaciones con garantía real

Los porcentajes de cobertura de estas operaciones serán, en función del tipo de garantía, los que se indican a continuación:

(i) Operaciones con garantía real sobre viviendas terminadas

El porcentaje de cobertura a aplicar a los instrumentos de deuda que cuenten con garantía de primera hipoteca sobre viviendas terminadas, así como a los arrendamientos financieros sobre tales bienes, siempre que su riesgo vivo sea igual o inferior al $80 \%$ del valor de tasación de las viviendas, será el $2 \%$. 
Transcurridos tres años sin que se extinga la deuda o la entidad adquiera la propiedad de las viviendas, se considerará que la entidad no puede o tiene la intención de adjudicárselas, y se aplicarán a los riesgos vivos los siguientes porcentajes de cobertura:

Más de 3 años, sin exceder de 4 años 25\%

Más de 4 años, sin exceder de 5 años $50 \%$

Más de 5 años, sin exceder de 6 años $75 \%$

Más de 6 años $100 \%$

No obstante lo anterior, el porcentaje de cobertura a aplicar a las operaciones clasificadas como dudosas por morosidad del cliente por acumulación de importes morosos en otras operaciones, mientras se hallen al corriente de pago, será del $1 \%$.

A estos efectos, se consideran viviendas los inmuebles utilizados como despachos, oficinas, etc., siempre que hubiesen sido construidos con fines residenciales, sigan siendo legalmente susceptibles de dicho uso y no requieran una transformación importante para su reutilización como vivienda.

Si finalmente la entidad adquiere las viviendas, se liberarán las coberturas por riesgo de crédito previamente constituidas siempre que su valor de adquisición menos los costes estimados de venta (que serán al menos del $30 \%$ de dicho valor) sea superior al importe de la deuda sin considerar las coberturas, salvo que el valor de adquisición sea superior al valor hipotecario, en cuyo caso se tomará como referencia este último valor.

(ii) Otras operaciones con garantía real

Los porcentajes de cobertura aplicables a las operaciones que cuenten con garantías reales sobre bienes inmuebles, incluidas aquellas operaciones con garantías sobre viviendas terminadas excluidas de la letra b.(i) anterior, siempre que la entidad haya iniciado los trámites para ejecutar dichos bienes y éstos tengan un valor sustancial en relación con el importe de la deuda, serán los que se indican a continuación, distinguiendo según que el cliente sea una empresa o empresario u otro tipo de cliente:

Empresas y empresarios Resto de clientela

Hasta 6 meses $4,5 \% 3,8 \%$

Más de 6 meses, sin exceder de 12 23,6\% 23,3\%

Más de 12 meses, sin exceder de 18 55,3\% 47,2\% Más de 18 meses, sin exceder de 24 81,4\% $79,3 \%$ Más de 24 meses $100 \% 100 \%$

La escala anterior se aplicará a las operaciones clasificadas como dudosas por morosidad del cliente por acumulación de importes morosos en otras operaciones. A estos efectos, se considerará como fecha para el cálculo del porcentaje de cobertura de éstas operaciones la del importe vencido más antiguo que permanezca impagado, o la de la calificación de los activos como dudosos si es anterior.

Cuando no sea posible identificar las operaciones que realizan las personas físicas en su calidad de empresarios, se les aplicarán a todas sus operaciones los porcentajes fijados para el resto de la clientela.

Si finalmente la entidad adquiere las viviendas, se liberarán las coberturas por riesgo de crédito previamente constituidas siempre que su valor de adquisición menos los costes estimados de venta (que serán al menos del $30 \%$ de dicho valor) sea superior al importe de la deuda sin considerar las coberturas, salvo que el valor de adquisición sea superior al valor hipotecario, en cuyo caso se tomará como referencia este último valor.

18. Las operaciones a nombre de clientes distintos de aquellos a los que se refiere el siguiente apartado que cuenten con alguna de las garantías pignoraticias que se indican a continuación se cubrirán aplicando los siguientes criterios:

a) Las operaciones que cuenten con garantías dinerarias parciales se cubrirán aplicando a la diferencia entre el importe por el que estén registradas en el activo y el valor actual de los depósitos los porcentajes de cobertura del apartado anterior correspondientes a las operaciones sin garantía.

b) Las operaciones que cuenten con garantías pignoraticias parciales sobre participaciones en instituciones financieras monetarias o valores representativos de deuda emitidos por las Administraciones Públicas o entidades de crédito mencionadas en las clases de riesgo como "sin riesgo apreciable", u otros instrumentos financieros cotizados en mercados activos, se cubrirán aplicando a la diferencia entre el importe por el que estén registradas en el activo y el 90 por ciento del valor razonable de dichos instrumentos financieros los porcentajes de cobertura del apartado anterior correspondientes a las operaciones sin garantía.

19. Las operaciones enumeradas entre las clases de riesgo como "sin riesgo apreciable" se analizarán individualmente, siendo la cobertura necesaria la diferencia entre el importe registrado en el activo y el valor actual de los flujos de efectivo que se espera cobrar.

20. En las operaciones de arrendamiento financiero, las cuotas vencidas no cobradas hasta el momento de recuperar materialmente la posesión o el uso de los bienes cedidos seguirán el tratamiento de cobertura previsto para las restantes operaciones.

Cuando se haya decidido rescindir el contrato para recuperar el bien, si éste tuviese un valor razonable inferior al valor en libros del arrendamiento financiero, se procederá a realizar una corrección de valor por deterioro de activos por el importe estimado de la pérdida; en tanto se determine el valor razonable con las peritaciones o valoraciones que procedan, el importe de la corrección de valor no será inferior al 10\% del valor en libros del arrendamiento financiero en el caso de bienes inmuebles (excepción hecha de los destinados a vivienda, oficinas o locales comerciales polivalentes, que no requerirán cobertura adicional), y del $25 \%$ en el caso de las instalaciones y los bienes muebles.

21. Las operaciones en las que concurran otras circunstancias, además de la morosidad, para calificarlas como dudosas se cubrirán por el importe que suponga más exigencia. Las operaciones de importe significativo para la entidad se analizarán individualmente para 
determinar si procede cubrirlas por encima de los porcentajes indicados en los apartados anteriores

1.1.2. Activos dudosos por razones distintas de la morosidad del cliente

22. Los instrumentos de deuda clasificados como dudosos por razones distintas de la morosidad se analizarán individualmente. Su cobertura será igual a la diferencia entre el importe registrado en el activo y el valor actual de los flujos de efectivo que se espera cobrar.

Con carácter general, la cobertura de estas operaciones no podrá ser inferior al $25 \%$ de los saldos calificados como dudosos. Cuando la calificación como dudoso se haya realizado porque el cliente presenta una estructura económica o financiera inadecuada, su cobertura será, al menos, del 10\%. La cobertura de los riesgos de clientes declarados en convenio de acreedores para los que no se haya iniciado la fase de liquidación se rebajará al 10\% cuando, transcurrido un año desde la inscripción en el Registro Mercantil del auto de aprobación del convenio, se esté cumpliendo fielmente el mismo y la evolución de la situación patrimonial y financiera de la empresa reduzca las incertidumbres sobre el reembolso de los débitos, todo ello salvo que se hayan pactado intereses notoriamente inferiores a los de mercado.

En las operaciones con garantía real sobre viviendas terminadas y en las operaciones de arrendamiento financiero sobre bienes inmuebles se realizarán las coberturas que correspondan una vez deducido del importe del riesgo el 70 por ciento del valor de tasación de los inmuebles siempre que no existan dudas sobre la posibilidad de separar el bien de la masa concursal y reintegrarlo, en su caso, a la de la entidad de crédito.

1.1.3. Activos subestándar

23. Las operaciones clasificadas en la categoría de riesgo subestándar se analizarán para determinar su cobertura necesaria, que, necesariamente, será superior a la cobertura genérica que le correspondería de estar clasificada como riesgo normal. Además, las dotaciones netas que se realicen en el período en el que se clasifique una operación en esta categoría deberán ser superiores a las dotaciones que se deberían realizar de mantenerse la operación clasificada como riesgo normal.

En particular, se aplicarán los siguientes criterios:

a) La cobertura a realizar para cada uno de los grupos homogéneos de instrumentos de deuda clasificados como riesgos subestándar por pertenecer a un colectivo en dificultades se estimará por algún procedimiento por el que se obtengan unos importes similares a la diferencia entre el importe registrado en el activo para dichos instrumentos y el valor actual de los flujos de efectivo que se espera cobrar para el grupo, descontados al tipo de interés contractual medio. En todo caso, los porcentajes de cobertura serán inferiores a los que les correspondería de aplicar los criterios del apartado 1.1.2 anterior.

b) A los créditos que no se encuentren adecuadamente documentados cuyo importe sea superior a 25.000 euros se les aplicará un porcentaje de cobertura del $10 \%$.

1.2 Riesgos y compromisos contingentes

24. Los riesgos y compromisos contingentes dudosos, excepto los avales y demás cauciones, se provisonarán por un importe igual a la estimación de las cuantías que se espera desembolsar que se consideren no recuperables efectuada con criterios de prudencia valorativa. En el cálculo de las provisiones se aplicarán criterios similares a los fijados para los activos dudosos por razones distintas de la morosidad del cliente.

La calificación como dudoso de un riesgo o compromiso contingente implicará, en su caso, la reclasificación del importe que por él esté reconocido en la partida "periodificaciones" de pasivo a la partida "provisiones para riesgos y compromisos contingentes", así como la dotación de provisiones hasta alcanzar la cobertura necesaria de acuerdo con este anejo. Adicionalmente, se reconocerá una corrección de valor por deterioro de activos hasta el importe registrado, en su caso, en la partida "otros activos financieros", siempre y cuando el deudor principal avalado sea el responsable de hacer frente a las comisiones pendientes de pago asociadas con la garantía financiera, o dicho importe se considere de dudoso cobro.

25. Los avales y demás cauciones prestados clasificados como dudosos se provisionarán en un importe igual al que, con un criterio de prudencia valorativa, se estime no recuperable. En todo caso, los importes dudosos se cubrirán como mínimo con los porcentajes de cobertura establecidos para los activos dudosos con las siguientes precisiones:

a) Cobertura por razón de la morosidad del cliente

(i) En los avales financieros clasificados como dudosos por razón de la morosidad de los riesgos que garantizan, así como en los riesgos dinerarios derivados de dichos avales, se aplicarán, en función de las garantías con las que cuente la entidad avalista, los mismos porcentajes de cobertura que, por razón de morosidad, correspondiesen a los riesgos dinerarios que garantizan, tomando como fecha determinante para contar el plazo para la fijación del porcentaje mínimo de cobertura la del vencimiento de la primera cuota o plazo del riesgo dinerario impagado por el avalado a sus prestamistas que permanezca, total o parcialmente, pendiente de pago a la fecha del balance.

(ii) En los avales no financieros y en los riesgos dinerarios derivados de los mismos, la fecha que se debe tomar a efectos de la fijación del porcentaje mínimo de cobertura será la más antigua de las que el avalado haya sido requerido de pago por el beneficiario del aval entre las que, a la fecha del balance, permanezca impagado algún importe, salvo cuando la reclamación se hubiese efectuado directamente a la entidad avalista, en cuyo caso se tomará la fecha de este requerimiento. 
(iii) Se exceptúa de lo dispuesto en los puntos precedentes el importe de los riesgos cubierto por las garantías mencionadas en el apartado 7.a).(i) de esta anejo como "sin riesgo apreciable" .

b) Cobertura por razones distintas de la morosidad del cliente

(i) Los avales financieros se provisionarán íntegramente si los avalados están declarados en concurso de acreedores para los que se haya declarado o conste que se vaya a declarar la fase de liquidación o sufran un deterioro notorio e irrecuperable de su solvencia, aunque el beneficiario del aval no haya reclamado su pago.

(ii) Los avales financieros en los que el avalado presente patrimonio negativo o pérdidas continuadas, se encuentre en concurso de acreedores para el que no se haya declarado o vaya a declarar la fase de liquidación, o se manifieste un retraso generalizado en los pagos, o circunstancias similares, se provisionarán, al menos, en un 25 por ciento de su importe total, aunque el beneficiario del aval no haya reclamado su pago.

(iii) En los demás avales y garantías clasificados como dudosos por razones distintas de la morosidad, los importes no reclamados por el beneficiario del aval se provisionarán, al menos, en un 10 por ciento, y los reclamados se provisionarán con los porcentajes que, en función de la situación del avalado, corresponda aplicar conforme a los criterios que se establecen en los puntos (i) y (ii) anteriores.

(iv) Se exceptúa de lo dispuesto en los puntos precedentes el importe de los riesgos que dispongan de las garantías mencionadas en el apartado 7.a) (i) de este anejo, o de hipoteca sobre los bienes a los que se refiere el apartado 17.b) (i) de este anejo relativo a "operaciones con garantía real sobre viviendas terminadas", siempre que, en este último caso, no exista duda de que el riesgo dinerario que pudiera derivarse del aval gozaría de derecho de separación en un concurso de acreedores.

26. Los riesgos contingentes clasificados en la categoría de riesgo subestándar se analizarán para determinar su cobertura necesaria, que en todo caso será superior a la cobertura genérica que les correspondería de estar clasificados como riesgo normal.

2. Cobertura genérica

27. Las entidades cubrirán las pérdidas inherentes de los instrumentos de deuda no valorados por su valor razonable con cambios en la cuenta de pérdidas de pérdidas y ganancias, así como de los riesgos contingentes, clasificados como riesgo normal teniendo en cuenta la experiencia histórica de deterioro y las demás circunstancias conocidas en el momento de la evaluación. A estos efectos, las pérdidas inherentes son las pérdidas incurridas a la fecha de los estados financieros, calculadas con procedimientos estadísticos, que están pendientes de asignar a operaciones concretas.

28. El Banco de España, sobre la base de su experiencia y de la información que tiene del sector bancario español, ha determinado que el método e importe de los parámetros que las entidades deberán utilizar para el cálculo de los importes necesarios para la cobertura de las pérdidas por deterioro inherentes en los instrumentos de deuda y riesgos contingentes clasificados como riesgo normal, que estén registrados en las entidades españolas o correspondan a operaciones a nombre de residentes en España registradas en los libros de entidades dependientes extranjeras, es el que se desarrolla en el siguiente apartado. El Banco de España actualizará periódicamente, mediante la modificación correspondiente de esta Circular, los parámetros utilizados en el método de acuerdo con la evolución de los datos del sector.

Para la estimación de la cobertura genérica correspondiente a operaciones con no residentes en España registradas en entidades dependientes extranjeras, se aplicarán los métodos y criterios que se indican en el apartado siguiente, adaptados a las circunstancias particulares del país en el que opere la entidad dependiente. A estos efectos, las entidades tomarán como referencia exigible los parámetros que se indican en la letra b) del siguiente apartado.

29. El método de estimación de la cobertura genérica mencionado en el apartado anterior es el siguiente:

a) La dotación genérica a realizar en cada ejercicio será igual a (i) la suma del resultado de multiplicar el valor, positivo o negativo, de la variación en el periodo del importe de cada una de las clases de riesgo por el parámetro a que les corresponda, más (ii) la suma del resultado de multiplicar el importe total de las operaciones incluidas en cada una de las clases de riesgo al final del período por su correspondiente parámetro $\beta$, menos (iii) el importe de la dotación neta para cobertura específica global realizada en el periodo.

b) Los parámetros $\alpha$ y $\beta$ tienen en cuenta la pérdida inherente histórica y los ajustes para adaptarlos a las circunstancias económicas actuales. Sus importes para cada una de las clases de riesgo son:

(i) Sin riesgo apreciable $0 \% 0 \%$

(ii) Riesgo bajo $0,6 \% 0,11 \%$

(iii) Riesgo medio-bajo $1,5 \% 0,44 \%$

(iv) Riesgo medio $1,8 \% 0,65 \%$

(v) Riesgo medio-alto $2,0 \% 1,10 \%$

(vi) Riesgo alto $2,5 \% 1,64 \%$

c) El saldo global de la cobertura genérica deberá estar comprendido en todo momento entre el $33 \%$ y el $125 \%$ del importe que resulte de sumar el producto que se obtiene de multiplicar el importe de cada clase de riesgo por su correspondiente parámetro $\alpha$. 
d) Los importes a considerar como base para el cálculo de las provisiones genéricas para la cobertura de los riesgos contingentes serán los importes calculados según lo preceptuado en el apartado 2 de la norma sexagésima quinta de esta Circular ponderados por los porcentajes establecidos en la norma decimocuarta de la Circular 5/1993, de 26 de marzo.

e) Las dotaciones netas para cobertura específica global son las dotaciones realizadas para la cobertura específica de insolvencias imputables al cliente de los instrumentos de deuda y riesgos contingentes menos las recuperaciones de dichas coberturas específicas y de activos fallidos realizadas en el período. Este concepto no incluye las dotaciones por riesgo-país.

B) COBERTURA DEL RIESGO-PAÍS

30. Los importe de los instrumentos de deuda y riesgos contingentes clasificados a efectos de riesgopaís en los grupos 3 a 6, con la excepción de las operaciones indicadas en el apartado 12 de este anejo, se deberán cubrir, al menos, con los siguientes porcentajes:
a) Grupo 3 $10,1 \%$
b) Grupo 4
$22,8 \%$
c) Grupo 5 $83,5 \%$ $100 \%$

d) Grupo 6

No obstante lo anterior, los créditos interbancarios de plazo no superior a tres meses se cubrirán por el $50 \%$ de las coberturas establecidas en este apartado, siempre que el país esté incluido en los grupos 3 ó 4 a efectos de riesgo-país y haya atendido normalmente su servicio, sin prórrogas o renovaciones.

31. Los apoyos financieros, dinerarios o de firma, a sucursales y entidades dependientes y multigrupo residentes en países clasificados en los grupos 3 a 6 a efectos de riesgo-país, denominados en una moneda diferente de la del país en el que radiquen, darán lugar a la constitución de coberturas por riesgo-país en los estados individuales de las entidades que presten el apoyo, y, en su caso, también en los estados consolidados, aunque dichos apoyos no figuren en dichos estados como consecuencia de su proceso de elaboración, salvo que estuviesen financiando activos ya cubiertos por riesgo-país 


\section{REFERENCES}

BANCO DE ESPAÑA (2004). Circular 4/2004, of 22 December, to credit institutions, concerning rules on public and confidential financial information, and models of financial statements (BOE, 30 December 2004).

BERNE UNION (2007). 2007 Yearbook.

BP (2007). BP Statistical Review of World Energy, June.

BURTON, DAVID and ALESSANDRO ZANELLO (2007). "Asia Ten Years After", Finance \& Development, Volume 44, Number 2, International Monetary Fund, June.

CESCE (2006). Informe Anual.

COLLIER, PAUL (2003). Natural Resources, Development and Conflict: Channels of causation and Policy Interventions, World Bank, April 28.

EICHENGREEN, BARRY, RICARDO HAUSMANN and UGO PANIZZA (2002). Original Sin: The Pain, the Mystery, and the Road to Redemption, November, Inter-American Development Bank, Washington, D.C.

EICHENGREEN, BARRY and MICHAEL MUSSA (1998). Capital Account Liberalization: Theoretical and Practical Aspects, IMF Occasional Paper 172, September 30.

FEDERAL DEPOSIT INSURANCE CORPORATION (1999). Guide to the Interagency Country Exposure Review Committee Process, Federal Deposit Insurance Corporation, November.

IMF (2005). Global Financial Stability Report, September.

- (2006). Global Financial Stability Report, April.

- (2007a). Global Financial Stability Report, April.

- (2007b). World Economic Outlook, April.

- (2007c). World Economic Outlook, October.

IRANZO, SILVIA and M. ${ }^{a}$ DEL CARMEN CARRASCO (2008). "La situación energética en Latinoamérica", Boletín Económico, Banco de España, Febrero.

IRANZO, SILVIA and ISABEL HERRERO (2007). "La estrategia de China en África", Boletín Económico del ICE n. ${ }^{\circ}$ 2909, 16-30 April.

KHOURY, SARKIS JOSEPH and CHUNSHENG ZHOU (2003). Country risk: existing models and new horizons, Handbook of International Banking, edited by Andrew W. Mullineux and Victor Murinde, Edward Elgar, Cheltenham, UK. Northampton, MA, USA.

NATH, HIRANYA K. (2004). Country Risk Analysis: A Survey, Southern Methodist University, March.

REQUEIJO, JAIME (2006). Anatomía de las crisis financieras, McGraw Hill.

SACHS, JEFFREY and ANDREW M. WARNER (1995). Natural resource abundance and economic growth, NBER Working Paper W5398, December.

SÁIZ ÁLVAREZ, JOSÉ MANUEL (2007). Credibilidad Monetaria y Currency Board Agreements (CBA): ¿Hacia la formación de una integración monetaria china?, Universidad Antonio de Nebrija, April.

SALA-I-MARTIN, XAVIER and ARVIND SUBRAMANIAN (2003). Addressing the Natural Resource Curse: An Illustration from Nigeria, IMF Working Paper 03/019, International Monetary Fund, Washington, D.C.

SCHILLER, ROBERT (1981). "Do stock prices move too much to be justified by subsequent changes in dividends?", American Economic Review.

WORLD BANK (2006). Doing Business 2007. How to reform.

ECONOMIST INTELLIGENCE UNIT. www.eiu.com.

FITCH. www.fitchratings.com

FREEDOM HOUSE. Www.freedomhouse.org

INSTITUTE OF INTERNATIONAL FINANCE. www.iif.com.

INTERNATIONAL MONETARY FUND. www.imf.org.

JP MORGAN. http:/morganmarkets.com.

MOODY's. www.moodys.com.

OECD. www.oecd.org.

PARIS CLUB. www.clubdeparis.org.

STANDARD \& POOR's. www. ratingsdirect.com.

THE ECONOMIST. www.economist.com.

WORLD BANK. www.worldbank.org. 
BANCO DE ESPAÑA PUBLICATIONS

\section{OCCASIONAL PAPERS}

0501 JOSÉ RAMÓN MARTÍNEZ-RESANO: Size and heterogeneity matter. A microstructure-based analysis of regulation of secondary markets for government bonds.

0502 ALICIA GARCÍA-HERRERO, SERGIO GAVILÁ AND DANIEL SANTABÁRBARA: China's banking reform: an assessment of its evolution and possible impact.

0503 ANA BUISÁN, DAVID LEARMONTH AND MARÍA SEBASTIÁ BARRIEL: An industry approach to understanding export performance: stylised facts and empirical estimation.

0504 ANA BUISÁN AND FERNANDO RESTOY: Cross-country macroeconometric heterogeneity in EMU.

0505 JOSÉ LUIS MALO DE MOLINA: Una larga fase de expansión de la economía española.

0506 VÍCTOR GARCÍA-VAQUERO AND JORGE MARTÍNEZ: Fiscalidad de la vivienda en España.

0507 JAIME CARUANA: Monetary policy, financial stability and asset prices.

0601 JUAN F. JIMENO, JUAN A. ROJAS AND SERGIO PUENTE: Modelling the impact of aging on Social Security expenditures.

0602 PABLO MARTÍN-ACEÑA: La Banque de France, la BRI et la création du Service des Études de la Banque d'Espagne au début des années 1930. (There is a Spanish version of this edition with the same number.)

0603 CRISTINA BARCELÓ: Imputation of the 2002 wave of the Spanish Survey of Household Finances (EFF).

0604 RAFAEL GÓMEZ AND PABLO HERNÁNDEZ DE COS: The importance of being mature: The effect of demographic maturation on global per-capita income.

0605 JUAN RUIZ AND JOSEP VILARRUBIA: International recycling of petrodolars. (The original Spanish version has the same number.)

0606 ALICIA GARCÍA-HERRERO AND SERGIO GAVILÁ: Posible impacto de Basilea Il en los países emergentes.

0607 ESTHER GORDO, JAVIER JAREÑO AND ALBERTO URTASUN: Radiografía del sector de servicios en España.

0608 JUAN AYUSO, ROBERTO BLANCO AND FERNANDO RESTOY: House prices and real interest rates in Spain.

0701 JOSÉ LUIS MALO DE MOLINA: Los principales rasgos y experiencias de la integración de la economía española en la UEM.

0702 ISABEL ARGIMÓN, FRANCISCO DE CASTRO AND ÁNGEL LUIS GÓMEZ: Una simulación de los efectos de la reforma del IRPF sobre la carga impositiva

0703 YENER ALTUNBAŞ, ALPER KARA AND ADRIAN VAN RIXTEL: Corporate governance and corporate ownership: The investment behaviour of Japanese institutional investors.

0704 ARTURO MACÍAS AND ÁLVARO NASH: Efectos de valoración en la posición de inversión internacional de España.

0705 JUAN ÁNGEL GARCÍA AND ADRIAN VAN RIXTEL: Inflation-linked bonds from a central bank perspective.

0706 JAVIER JAREÑO: Las encuestas de opinión en el análisis coyuntural de la economía española.

0801 MARÍA J. NIETO AND GARRY J. SCHINASI: EU framework for safeguarding financial stability: Towards an analytical benchmark for assessing its effectiveness.

0802 SILVIA IRANZO: Delving into country risk.

\section{BANCODEESPAÑA}

Eurosistema
Unidad de Publicaciones Alcalá, 522; 28027 Madrid Telephone +3491338 6363. Fax +34913386488 e-mail: publicaciones@bde.es www.bde.es 